THALES SARDINHA GARCIA SOUZA

EFEITO DA RUGOSIDADE NO DESGASTE DE PUNÇÕES DE CONFORMAÇÃO A FRIO

São Paulo

2016 
THALES SARDINHA GARCIA SOUZA

\section{EFEITO DA RUGOSIDADE NO DESGASTE DE PUNÇÕES DE CONFORMAÇÃO A FRIO}

Dissertação apresentada à Escola Politécnica da Universidade de São Paulo para obtenção do título de Mestre em Ciências.

Área de Concentração: Engenharia Mecânica

Orientador: Prof. Dr. Roberto Martins de Souza

São Paulo

2016 
Este exemplar foi revisado e corrigido em relação à versão original, sob responsabilidade única do autor e com a anuência de seu orientador.

São Paulo, de de

Assinatura do autor:

Assinatura do orientador:

SOUZA, THALES SARDINHA GARCIA

EFEITO DA RUGOSIDADE NO DESGASTE DE PUNÇÕES DE

CONFORMAÇÃO A FRIO / T. S. G. SOUZA - versão corr. -- São Paulo, 2016. $103 \mathrm{p}$.

Dissertação (Mestrado) - Escola Politécnica da Universidade de São

Paulo. Departamento de Engenharia Mecânica.

1.CONFORMAÇÃO MECÂNICA 2.FERRAMENTAS (DESGASTE)

3.DESGASTE DOS MATERIAIS 4.RUGOSIDADE SUPERFICIAL

I.Universidade de São Paulo. Escola Politécnica. Departamento de

Engenharia Mecânica II.t. 


\section{AGRADECIMENTOS}

Agradeço ao Presidente da Neumayer Tekfor Automotive Brasil Ltda., Sr. Jorge Jacomini, ao Gerente de Engenharia Maurício Schledorn e aos colegas Mauro Moraes de Souza e Juliano Savoy por terem acreditado e viabilizado este trabalho dentro de um ambiente industrial.

Ao Professor Dr. Roberto Martins de Souza por ter me recebido no Laboratório de Fenômenos de Superfície (LFS), por me orientar durante o desenvolvimento deste trabalho, por cobrar insistentemente uma revisão profunda da literatura e pelos questionamentos que me incentivaram a comparar os resultados práticos com os teóricos.

Ao Professor Dr. Raul Lima, por viabilizar minha transferência de área de concentração, utilizando sempre o bom senso e não apenas a burocracia instaurada nos diversos departamentos da USP.

Ao Professor Dr. Amilton Sinatora, por ser um marco na minha vida acadêmica e por apresentar um método de aula único e inovador.

Aos colegas de profissão Márcio Henrique Pereira, Paulo Sigoli, Márcio Silva, Ronaldo Silva, Gerson Roncoleta e Henrique, por contribuírem com suas respectivas áreas de atuação para essa pesquisa.

Aos colegas do LFS, Sebastian, Jimmy, Pablo, Tiago, Gustavo, Iramar, Rafael, Felipe e Rafael Ferreira que proporcionaram momentos ricos de discussão técnica.

Aos meus pais Juarez e Luciana, exemplos de uma vida vitoriosa, pelo constante incentivo nos estudos e por permitir meu crescimento pessoal e profissional sem que eu passasse pelas dificuldades que eles passaram.

À minha esposa Priscila, por ser minha eterna parceira e um exemplo de liderança. 
"Quando uma criatura humana desperta para um grande sonho e sobre ele lança toda força de sua alma, todo o universo conspira a seu favor" 


\section{RESUMO}

O custo de qualquer produto forjado para indústria automobilística é altamente influenciado pelos custos envolvidos durante o projeto e construção das ferramentas de conformação. Idealmente, essas ferramentas devem durar um número significativo de ciclos de conformação, de forma a diluir seu custo no maior número de peças possível. Diversos parâmetros afetam o comportamento do desgaste das ferramentas, sendo que as indústrias de forjados abordam as questões tribológicas de formas distintas. Além disso, um mal entendimento desses parâmetros pode levar a um desgaste de ferramenta prematuro. Esse trabalho analisa o efeito da rugosidade no desgaste de punções de conformação a frio. $O$ tribossistema adotado é a segunda operação de uma prensa mecânica horizontal e consiste em um punção de aço M2 endurecido em movimento relativo contra uma peça de aço SAE 10B22 normalizado. Foram fabricados quinze punções com três níveis de rugosidade e seus desgastes foram medidos após 52.000 e 102.000 ciclos de conformação. Um perfilômetro óptico 3D e um microscópio eletrônico de varredura foram utilizados para acessar as características superficiais dos punções, antes e após dos lotes de produção. Também foram realizadas análises na contra-peça e no meio interfacial "óleo". Os resultados obtidos mostraram que os punções de maior rugosidade falharam prematuramente enquanto os punções polidos e os de rugosidade intermediária apresentaram desgaste equivalentes. Considerando que o processo de polimento contribui significativamente para o custo de fabricação dos punções, espera-se que uma forjaria que consuma tais ferramentas em larga escala obtenha grandes benefícios econômicos com o presente trabalho.

Palavras-chave: Conformação a frio, desgaste de ferramenta, rugosidade. 


\begin{abstract}
The cost of any forged product for the automotive industry is highly influenced by the costs involved during the design and manufacturing of the forging tools. Ideally, these tools shall withstand a significant number of forging cycles, in order to distribute their manufacturing cost in as many parts as possible. There are several parameters that affect the tool wear behavior and forging companies have different approaches to address the tribological issues. Moreover, a misunderstanding of these parameters may lead to an undesirable premature tool wear. This work analyses the effect of roughness on the wear of cold forming punches. The adopted tribosystem is the second stage of a horizontal press and consists of a punch of M2 hardened steel in relative movement against a working piece of SAE 10B22 normalized steel. Fifteen punches were manufactured with three roughness levels and their wear was measured after 52.000 and 102.000 forging cycles. A 3D optical profiler and a Scanning Electronic Microscope (SEM) were used to access the surface characteristics of the punches before and after the production batches. Analysis of the counter body as well as of the interfacial element (oil) were also conducted. The results showed that all punches with higher roughness failed prematurely, while the polished ones as well as the intermediate ones presented equivalent wear. Considering that the polishing process contributes significantly to the manufacturing cost of the punches, it is expected that a forgery that consumes those tools in largescale can get great economic benefits with this work.
\end{abstract}

Key-words: Cold forming, tool wear, roughness. 


\section{LISTA DE FIGURAS}

Figura 1 - Produção anual de forjados no mundo e distribuição do consumo entre os diversos setores industriais (Adaptado de EUROFORGE, 2015)...........................14

Figura 2 - Distribuição das forjarias no Brasil e evolução do faturamento anual .......15

Figura 3 - Exemplos de componentes automotivos forjados a frio (SACMA GROUP, 2016)

Figura 4 - Tipos de máquinas utilizadas no processo de conformação a frio. (a) Prensa hidráulica vertical; (b) Prensa mecânica vertical; (c) Prensa mecânica horizontal.

Figura 5 - Exemplos de ferramentas utilizadas no processo de conformação a frio .21

Figura 6 - Exemplos de possíveis relações entre coeficiente de atrito e rugosidade imaginadas em um ambiente fabril (Autor).

Figura 7 - Representação esquemática do contato entre dois sólidos. i) A área aparente é igual a área real na análise macroscópica. ii) A área aparente é maior que a área real na análise microscópica. (Adaptado de BLAU, 2009) ......................24

Figura 8 - Pressões de contato entre asperezas (STACHOWIAK, 1993)

Figura 9 - (a) Princípio de operação de um perfilômetro de contato; (b) rugosímetro atual (HUTCHINGS, 1982; MITUTOYO, 2016)

Figura 10 - (a) Perfil de uma superfície real ampliada; (b) a mesma superfície, representada pelo perfilômetro com a escala vertical cinco vezes maior que a horizontal; (c) assim como (b), mas com uma escala vertical cinquenta vezes maior que a horizontal (HUTCHINGS, 1992)

Figura 11 - Rugosidade, ondulação e perfil ideal de uma superfície (WHITESTONE, 1994)

Figura 12 - (a) Uma ponta padrão de apalpador utilizada por perfilômetro de contato; (b) uma ponta mais fina utilizada para analisar superfícies mais refinadas (HUTCHINGS, 1992).

Figura 13 - Influência do tamanho da ponta do apalpador na leitura de uma mesma superfície.

Figura 14 - (a) Princípio de funcionamento de um perfilômetro óptico; (b) Perfilômetro óptico atual (TAYLOR HOBSON, 2016).

Figura 15 - (a) superfície com textura periódica; (b) superfície com textura aleatória... (Adaptado de MICHIGAN METROLOGY, LLC)

Figura 16 - Desenho encontrado na tumba de Djehutihotep mostrando um colosso com cerca de vinte e dois pés de altura sendo transportado sobre um trenó de madeira por 172 homens (PHYS.ORG, 2016)

Figura 17 - Rascunhos de Leonardo da Vinci: (a) Blocos similares em diversas orientações sendo puxados; (b) Bloco e cilindro escorregando em um plano horizontal com o auxilio de um barril e cordas; (c) estudo do efeito da pressão de contato na área real de contato e (d) primeira anotação de Leonardo sobre as leis do atrito 
Figura 18 - A relação entre coeficiente de atrito e rugosidade mostra uma região de rampa negativa causada por crescimento de junção excessivo e uma região positiva causada pelo intertravamento das asperezas. Entre elas, o atrito independe da rugosidade.

Figura 19 - Exemplos de superfícies que sofreram desgaste ...............................38

Figura 20 - Representação esquemática de um tribossistema e seus elementos....39

Figura 21 - Abrasão a dois e a três corpos (STACHOWIAK, 1993)

Figura 22 - Ilustração do contato entre uma partícula dura sob carga normal em uma superfície plana. (a) quando $\mathrm{Ha} / \mathrm{Hs}$ é maior que 1,2 e (b) quando $\mathrm{Ha} / \mathrm{Hs}$ é menor que 1,2

Figura 23 - Aspectos de superfícies danificadas por abrasão obtidas por MEV. a) Exemplo de microcorte causado por uma única partícula dura e b) cortes causados por múltiplas partículas (Cortesia de Jimmy Penagos - Laboratório de Fenômenos de Superfície da USP).

Figura 24 - Mecanismos do desgaste abrasivo: (a) Microcorte, (b) fratura, (c) fadiga por excessivo microsulcamento e (d) desplacamento (STACHOWIAK, 1993)..........43

Figura 25 - Tribossistema analisado e imagens obtidas por microscópio eletrônico de varredura (MEV): a) Tribossistema; b) Punção novo com 500 vezes de aumento; b) Punção usado com 300 vezes de aumento (Adaptado de FALCONNET, 2015) ......43

Figura 26 - Modelo de desgaste abrasivo causado por uma única partícula .............44

Figura 27 - Sequência de eventos no desgaste gerado por adesão ........................45

Figura 28 - Exemplo de trasferência de partículas metálicas causada por adesão (KOMVOPOULOS, 1985)

Figura 29 - Mecanismo de formação de sulcos em superfícies desgastadas pelo encruamento de partículas transferidas (STACHOWIAK, 1993) …...........................47

Figura 30 - Níveis de deformação em uma superfície desgastada .48

Figura 31 - (a) llustração do mecanismo de formação de partículas devido ao crescimento de trincas iniciadas na superfície; (b) Exemplo de formação de partícula gerada por desgaste por fadiga (STACHOWIAK, 1993)

Figura 32 - Imagem em MEV mostrando fratura por fadiga em um punção de aço AISI D1 utilizado para cortar chapas de aço inoxidável (ASM HANDBOOK, 1992) ..50

Figura 33 - Intensidade do desgaste em função da rugosidade em contatos lubrificados e não lubrificados. "h"é a espessura do filme elastohidrodinâmico e $\lambda$ é a espessura de filme específica (Adaptado de ZUM GAHR, 1987).

Figura 34 - Efeito da rugosidade das matrizes no atrito em ensaios de compressão de anel com óleo de baixa (a) e de alta (b) viscosidade (Adaptado de SCHEY, 1984)

Figura 35 - Aparato experimental conhecido como "load scanning test rig" (PODGORNIK, 2012)

Figura 36 - Efeito da preparação superficial na carga crítica para transferir o aço inoxidável para o cilindro de aço ferramenta D2 em deslizamento lubrificado (PODGORNIK, 2012) 
Figura 37 - (a) Máquina de polir assistida por robô; (b) Exemplo de ferramenta polida para operações de conformação a frio (GROENBAEK, 2008).

Figura 38 - Tribossistema analisado por Magri e tipos de topografias das ferramentas (Adaptado de MAGRI, 2011)

Figura 39 - Comparativo da topografia das matrizes nas 4 condições analisadas. (a) Antes da conformação e (b) após 50 ciclos (Adaptado de MAGRI, 2011) ................58

Figura 40 - Máquina de conformação a frio, 5 estágios .......................................59

Figura 41 - Interior da máquina 60

Figura 42 - Sequência de conformação do item analisado. As pré-formas de $3^{\underline{a}}$ e $4^{\underline{a}}$ operação foram escondidas por se tratar de know-how de fabricação da empresa TEKFOR.

Figura 43 - Tribossistema analisado: 2a operação

Figura 44 - Punções de 2a operação com topografias distintas utilizados no estudo

Figura 45 - Equipamentos utilizados a) Balança de precisão, b) Perfilômetro, c) Rugosímetro, d) Perfilômetro óptico 3D, e) Microscópio eletrônico de varredura ....63

Figura 46 - Geometria do punção de segunda operação. As características de 1 a 8 sofrem desgaste ao longo da produção seriada e foram monitoradas ao decorrer do trabalho

Figura 47 - Regiões de avaliação da rugosidade: (1) topo; (2) lateral .......................65

Figura 48 - a) Microdurômetro utilizado ; b) Regiões analisadas da ferramenta .......66

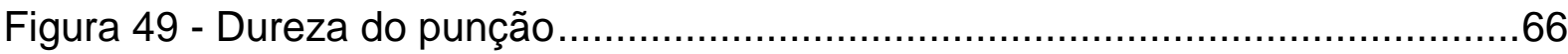

Figura 50 - Micrografia do punção em aço M2 temperado e revenido. ......................67

Figura 51 - Processo de beneficiamento da matéria-prima .....................................68

Figura 52 - Seção transversal da contra-peça e regiões de dureza medição de

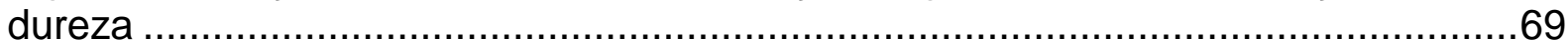

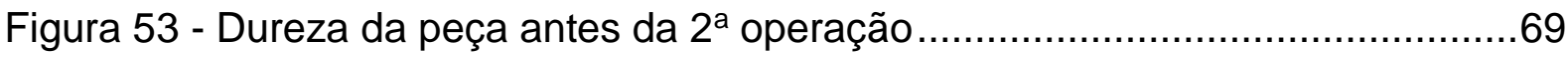

Figura 54 - Micrografia do material SAE10B22 após a esferoidização. ....................70

Figura 55 - (a) Óleo coletado e (b) membrana analisada após filtragem ..................72

Figura 56 - Punções de $2^{\mathrm{a}}$ operação após sucessívos lotes de produção .................73

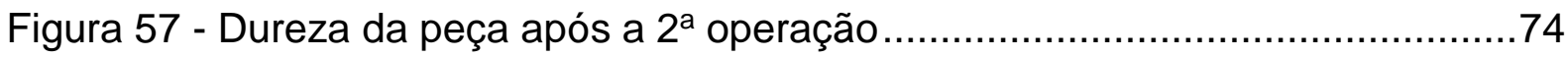

Figura 58 - Diferença de dureza entre corpo e contra-corpo...................................75

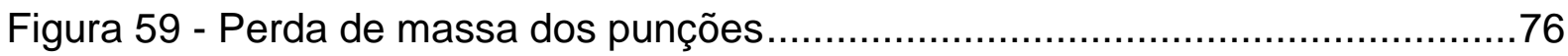

Figura 60 - Redução dimensional do diâmetro crítico ............................................77

Figura 61 - Resultado incoerente de topografia do punção 2 (Rugoso) novo ............78

Figura 62 - Resultado incoerente de topografia do punção 2 (Rugoso) após 50.000

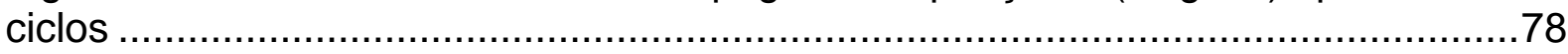

Figura 63 - Topografia e rugosidade do topo do punção 7 (Intermediário) novo .......79

Figura 64 - Topografia e rugosidade da lateral do punção 7 (Intermediário) novo ....79 
Figura 65 - Topografia e rugosidade do topo do punção 7 (Intermediário) após 50.000 ciclos

Figura 66 - Topografia e rugosidade da lateral do punção 7 (Intermediário) após 50.000 ciclos

Figura 67 - Topografia e rugosidade do topo do punção 12 (Polido) novo.

Figura 68 - Topografia e rugosidade do topo do punção 12 (Polido) após 50.000 ciclos

Figura 69 - Punção 2 (Rugoso) novo; (a) imagem de elétron secundário com aumento de 20 vezes, (b) 50 vezes, (c) 100 vezes, (d) 200 vezes, (e) 500 vezes e (f) imagem de elétron retroespalhado com aumento de 500 vezes

Figura 70 - Punção 2 (Rugoso) após 52.000 ciclos; (a) imagem de elétron secundário com aumento de 20 vezes, (b) 50 vezes, (c) 100 vezes, (d) 200 vezes, (e) imagem de elétron retroespalhado com aumento de 500 vezes, (f) idem (e) ......85

Figura 71 - Punção 7 (Intermediário) novo; (a) imagem de elétron secundário com aumento de 20 vezes, (b) 50 vezes, (c) 100 vezes, (d) 200 vezes, (e) 500 vezes e (f) imagem de elétron retroespalhado com aumento de 500 vezes

Figura 72 - Punção 7 (Intermediário) após 52.000 ciclos; (a) imagem de elétron secundário com aumento de 20 vezes, (b) 50 vezes, (c) 100 vezes, (d) 200 vezes, (e) imagem de elétron retroespalhado com aumento de 500 vezes, (f) idem (e) com aumento de 8000 vezes

Figura 73 - Punção 12 (Polido) novo; (a) imagem de elétron secundário com aumento de 20 vezes, (b) 50 vezes, (c) 100 vezes, (d) 200 vezes, (e) 500 vezes e (f) imagem de elétron retroespalhado com aumento de 500 vezes

Figura 74 - Punção 12 (Polido) após 52.000 ciclos; (a) imagem de elétron secundário com aumento de 20 vezes, (b) 50 vezes, (c) 200 vezes, (d) 100 vezes, (e) 200 vezes e (f) imagem de elétron retroespalhado com aumento de 200 vezes.

Figura 75 - Comparativo entre as maiores trincas encontradas nas seções transversais dos punções

Figura 76 - Mapeamento da distribuição de elementos químicos na seção transversal do punção 1 .....

Figura 77 - Mapeamento da distribuição de elementos químicos no raio do punção 2 .94

Figura 78 - Topografia de peças fabricadas com um punção rugoso (a), intermediário

(b) e polido (c) .95

Figura 79 - Partículas sólidas encontradas no óleo refrigerante .96 


\section{LISTA DE TABELAS}

Tabela 1 - Valores comparativos dos processos de forjamento (HIRSCHVOGEL, 1992)

Tabela 2 - Parâmetros bidimensionais de rugosidade (STACHOWIAK, 1993) .........28

Tabela 3 - Parâmetros tridimensionais de rugosidade (Adaptado de OLYMPUS) ....31

Tabela 4 - Fatores que influenciam o coeficiente de atrito de acordo com as

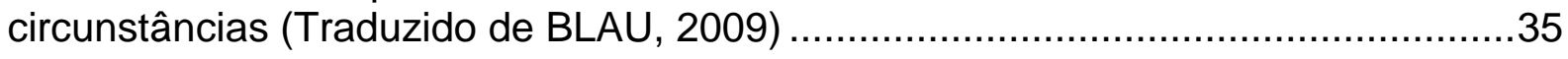

Tabela 5 - Descrição das amostras e respectivos parâmetros de rugosidade ...........55

Tabela 6 - Especificação da composição química nominal do aço ferramenta AISI M2

Tabela 7 - Especificação da composição química do aço SAE 10B22 (\% em massa) 


\section{SUMÁRIO}

1. INTRODUÇÃO .......................................................................................... 14

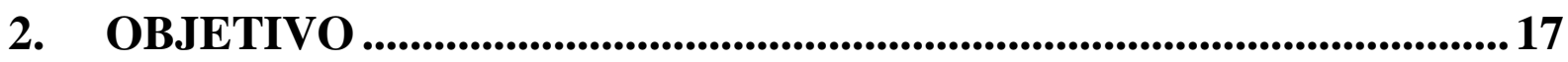

3. REVISÃO BIBLIOGRÁFICA.......................................................... 18

3.1. Conformação ……………………………………………………..... 18

3.2. Máquinas e ferramentas de conformação a frio .......................................20

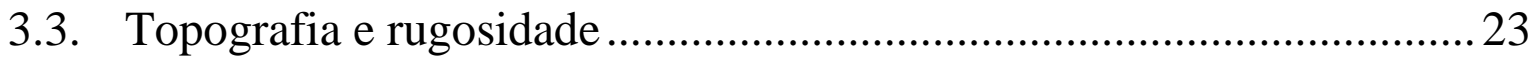

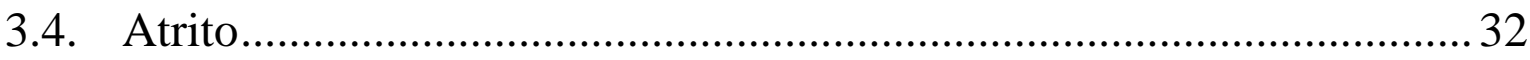

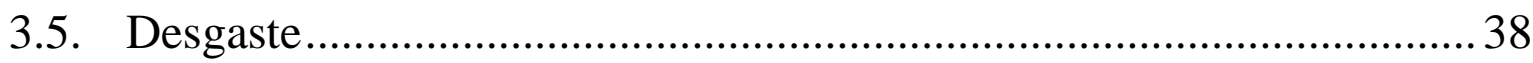

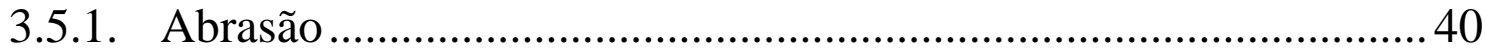

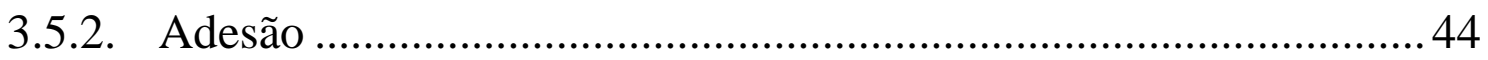

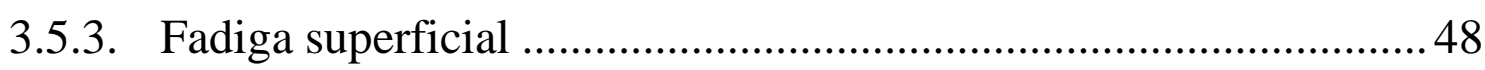

3.6. Relação entre rugosidade e desgaste ………………………………..... 50

4. MATERIAIS E MÉTODOS ....................................................................59

4.1. Apresentação e caracterização do tribossistema ……………………....59

4.2. Caracterização da ferramenta ("punção" ou "corpo") ........................... 61

4.3. Caracterização da matéria-prima ("peça" ou "contra-corpo")................67 67

4.4. Caracterização do meio interfacial "óleo" ...............................................71

5. RESULTADOS....................................................................................... 73

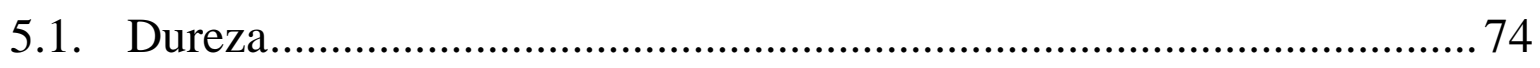

5.2. Perda de massa …………………………………………………. 75

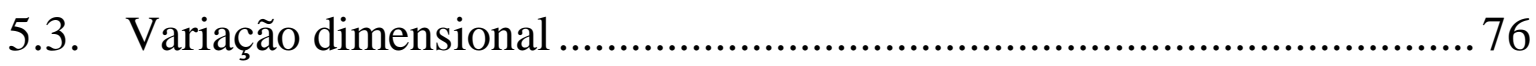

5.4. Rugosidade e topografia dos punções (corpo) ………………………..... 77

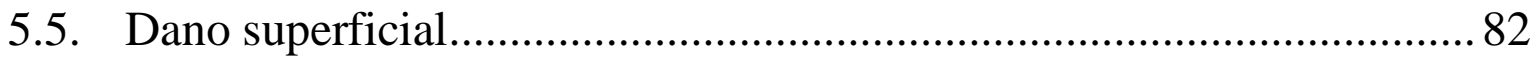

5.6. Análise da seção transversal dos punções .............................................91

5.7. Investigação de adesão ...................................................................... 93

5.8. Topografia da peça (contra-corpo) ...................................................... 94

5.9. Análise do meio interfacial (óleo) ........................................................96

6. CONCLUSÕES ....................................................................................97

7. TRABALHO FUTUROS............................................................................98

8. REFERÊNCIAS ....................................................................................99 


\section{INTRODUÇÃO}

Um estudo conduzido em 2013 pela Euroforge revelou que aproximadamente 25,7 milhões de toneladas de matéria-prima são forjadas anualmente, sendo que a China é responsável por transformar 39\% desse total, seguida pelos países que compõe a Euroforge. O Brasil ocupa o nono lugar com $2 \%$ do total, conforme mostrado na Figura 1. Nesse estudo, constatou-se também que o setor automotivo é o maior consumidor dos produtos forjados no mundo, com $58 \%$ do total (EUROFORGE, 2015).
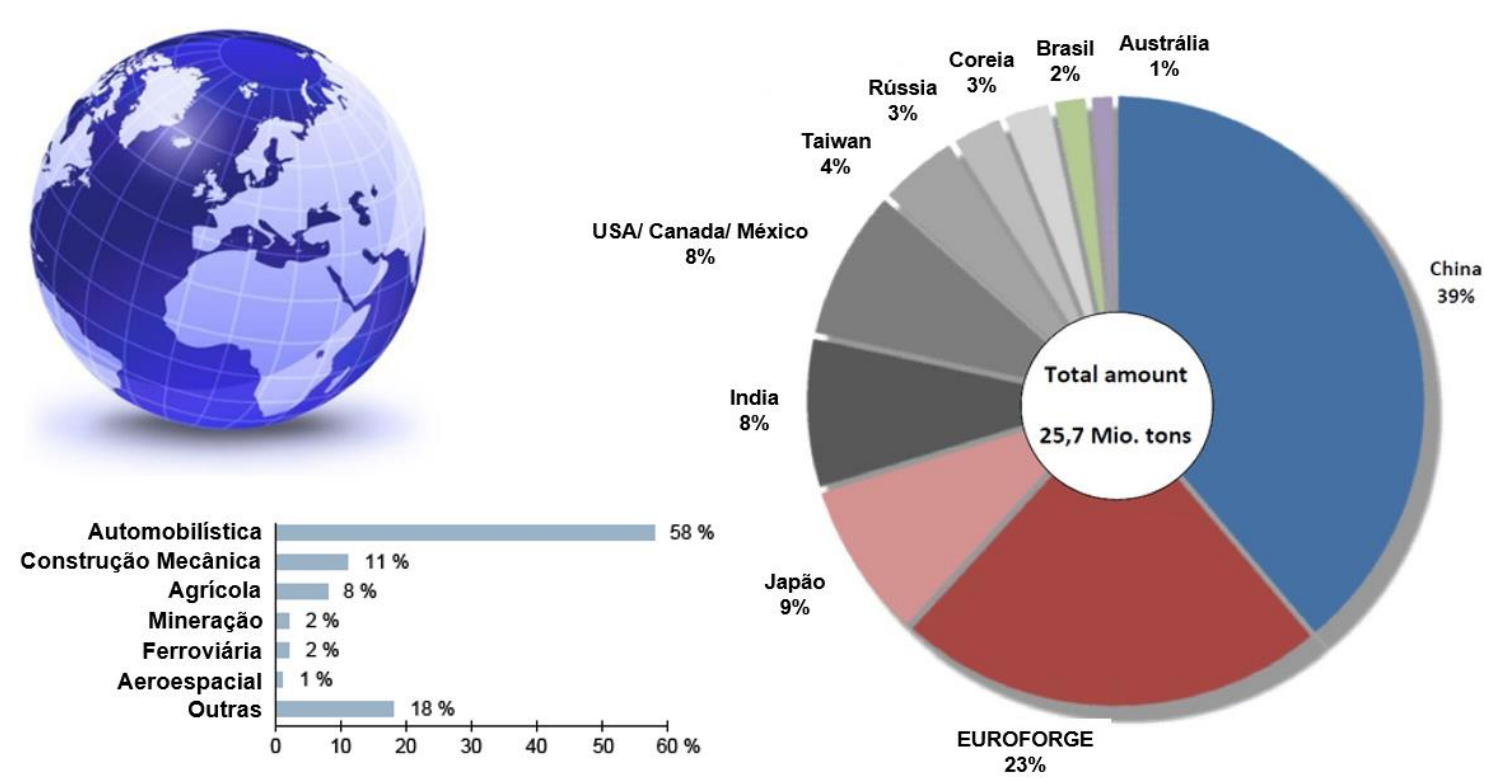

Figura 1 - Produção anual de forjados no mundo e distribuição do consumo entre os diversos setores industriais (Adaptado de EUROFORGE ${ }^{1}$, 2015)

No Brasil, a maioria das forjarias estão concentradas no sul e sudeste, conforme apresentado na Figura 2, sendo que juntas foram responsáveis por um faturamento aproximado de 2,47 bilhões de reais em 2014. A tendência decrescente do faturamento anual do setor, igualmente mostrada na Figura 2, pode ser explicada pela migração do consumo de aço forjado no automóvel para outros materiais ou processos, por exemplo, alumínio e componentes sinterizados (SOUZA, 2014).

\footnotetext{
${ }^{1}$ EUROFORGE é a associação dos fabricantes de produtos forjados da Europa.
} 


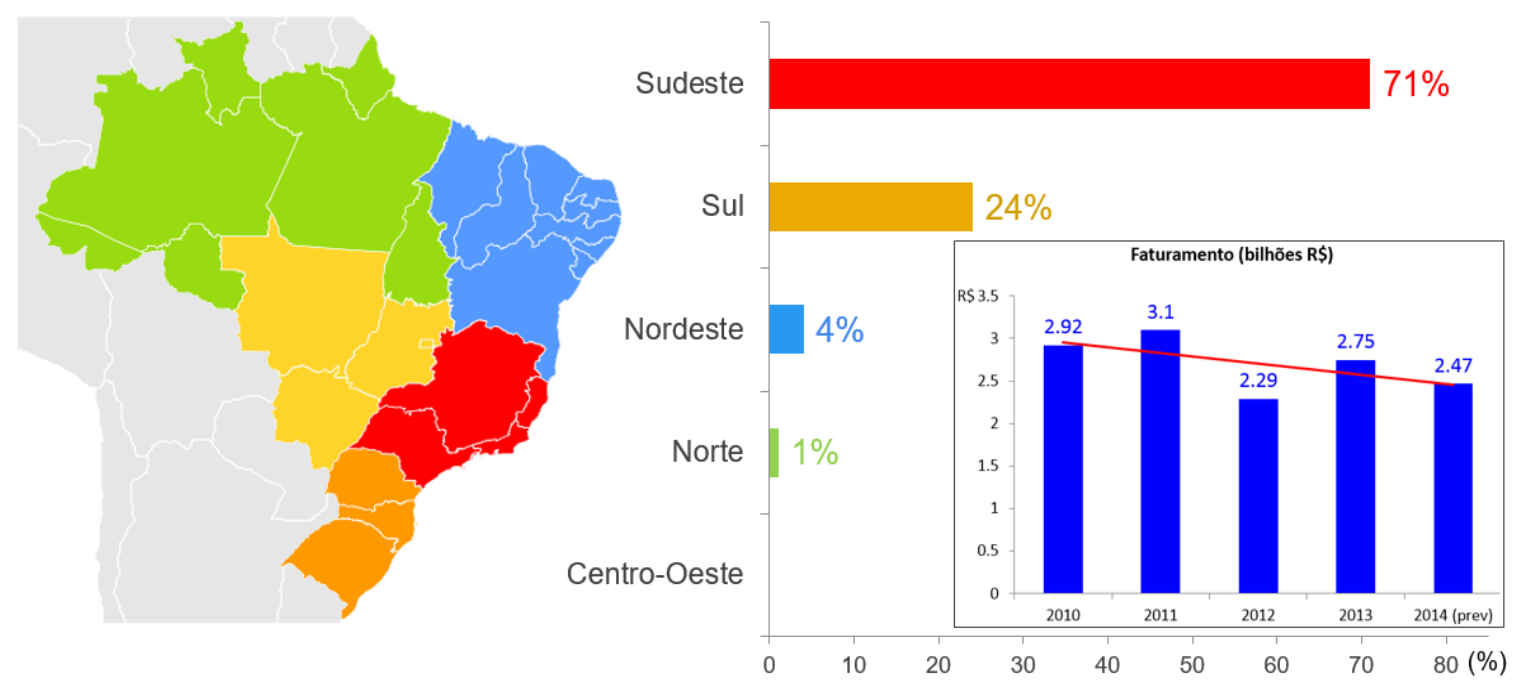

Figura 2 - Distribuição das forjarias no Brasil e evolução do faturamento anual (SOUZA, 2014)

Ainda que o faturamento anual siga uma trajetória decrescente, o processo de forjamento tem alta participação no cenário internacional quando comparado aos outros processos de fabricação.

A Figura 3 exemplifica alguns produtos obtidos por meio do processo de forjamento a frio com aplicação em veículos automotores. Os produtos variam desde geometrias simples como rebites, porcas e parafusos, até formas mais complexas como cubos de embreagem, juntas homocinéticas, engrenagens, fixadores especiais, eixos estriados, entre outras.

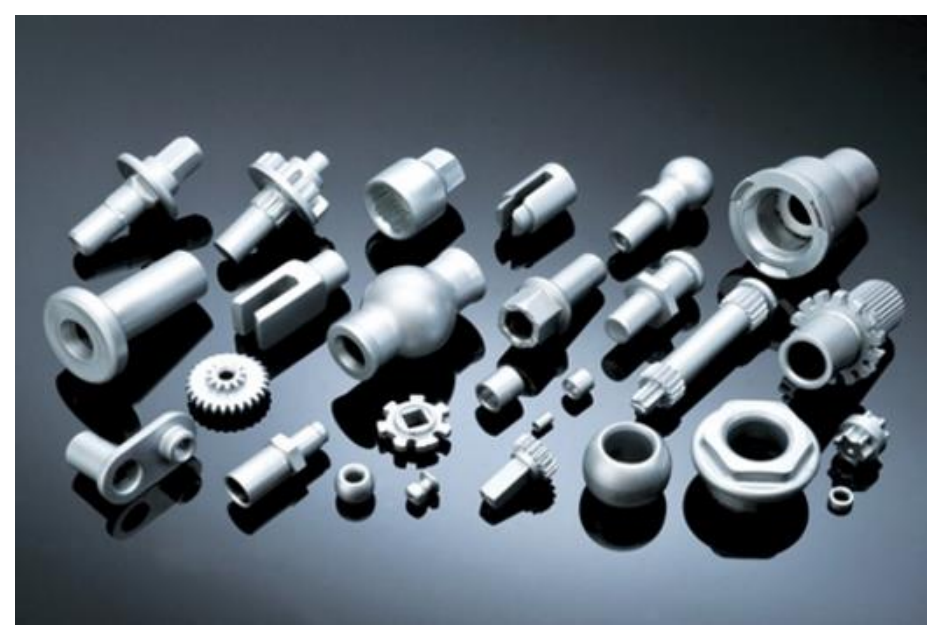

Figura 3 - Exemplos de componentes automotivos forjados a frio (SACMA GROUP, 2016)

A fabricação desses produtos depende necessariamente de um projeto e da construção das ferramentas de conformação, como punções, matrizes, buchas, extratores, garras, entre outras, e parte da movimentação econômica gerada pelas 
forjarias depende do desenvolvimento dessas ferramentas. Além disso, o preço dos produtos forjados depende fortemente do custo e da durabilidade do ferramental, ou seja, as ferramentas das prensas devem durar o máximo possível para que seus custos sejam diluídos em uma grande quantidade de produtos confeccionados.

Um relatório de uma indústria que tem como base processos de conformação revelou que, para peças com alta demanda, o custo do ferramental pode chegar a $10 \%$ do custo de um produto forjado a quente, e a $8 \%$ de um produto forjado a frio. Para itens de menor demanda, esses valores podem chegar até $20 \%$ do preço do produto. O mesmo relatório mostra que o processo de polimento, comumente efetuado após a usinagem de acabamento das ferramentas, representa em média $20 \%$ do custo de fabricação de uma ferramenta de conformação a frio (NEUMAYER TEKFOR AUTOMOTIVE BRASIL LTDA., 2015).

Nas últimas décadas, foram desenvolvidos diversos tipos de aços ferramenta que permitiram aumentar a dureza, a tenacidade e a resistência ao desgaste das ferramentas de conformação, contribuindo assim, para aumentar sua durabilidade. Outros desenvolvimentos com o mesmo propósito foram conduzidos focando em melhorias no processo de fabricação das ferramentas, seja por meio do uso de filmes finos ou por especificações de rugosidade superficial (POLOK, 2008; TILLMANN, 2010; PODGORNIK, 2012; ENGEL et al., 2011).

Nas forjarias, é comum ouvir que quanto mais lisa a superfície da ferramenta, melhor. Porém, quanto mais lisa, maior o tempo e o custo envolvido na sua produção. Portanto, um estudo que analise o efeito da rugosidade superficial no desgaste das ferramentas de conformação é de alta relevância econômica. 


\section{OBJETIVO}

O objetivo deste trabalho é analisar o efeito da rugosidade no desgaste de punções de conformação a frio. Partindo deste objetivo principal, apresentam-se outros objetivos específicos:

a) Identificar os tipos de desgaste presentes nas ferramentas;

b) Contribuir para redução de custos associados à fabricação das ferramentas. 


\section{REVISÃO BIBLIOGRÁFICA}

\subsection{Conformação}

O processo de conformação é definido pela norma DIN 8580 como a manufatura por meio de modificação plástica tridimensional, sem variação de volume e com coesão de material. Em contraste à deformação, a conformação é a modificação de forma com controle de geometria. Os processos de conformação são caracterizados por pouca ou nenhuma perda de material.

Os processos de conformação podem ser classificados em função da temperatura em que são realizados, e são comumente divididos em conformação a frio, a morno e a quente.

a) Conformação a frio: Quando o processo é realizado em até $0,3 \mathrm{da}$ temperatura homóloga.

b) Conformação a morno: Quando o processo é realizado entre 0,3 e 0,5 da temperatura homóloga.

c) Conformação a quente: Quando o processo é realizado entre 0,5 e 1,0 da temperatura homóloga.

A temperatura homóloga varia entre 0 e 1 , sendo 0 o zero absoluto e 1 a temperatura de fusão do material (DIETER, 1988).

Dependendo do tipo de conformação, o produto final apresentará características específicas. Estas características serão função da microestrutura da matéria-prima e das condições impostas pelo processo, tais como, tipo e grau de deformação, velocidade de deformação e temperatura em que o material é deformado.

A Tabela 1 apresenta um comparativo entre as diversas características dos processos de conformação a frio, a morno e a quente. Os valores apresentados servem apenas como referência e não devem ser tomados como valores absolutos, pois a fabricação de cada tipo de peça deve ser analisada de forma particular. 
Tabela 1 - Valores comparativos dos processos de forjamento (HIRSCHVOGEL, 1992)

\begin{tabular}{|c|c|c|c|}
\hline & Forjamento a quente & Forjamento a frio & Forjamento a morno \\
\hline Tolerância & IT 12 - IT 16 & IT 7 - IT 11 & IT 9 - IT 12 \\
\hline $\begin{array}{l}\text { Peso das peças } \\
\text { conformadas }\end{array}$ & $5 \mathrm{~g}-1500 \mathrm{~kg}$ & $1 \mathrm{~g}-50 \mathrm{~kg}$ & $100 \mathrm{~g}-50 \mathrm{~kg}$ \\
\hline $\begin{array}{l}\text { Lotes econômicos (peso } \\
\text { de } 1 \mathrm{~kg} \text { ) }\end{array}$ & min. 500 peças & min. 3000 peças & min. 1000 peças \\
\hline Aços conformáveis & todos & $\begin{array}{l}\text { aços de baixa liga } \\
(\mathrm{C}<0,45 \% \text {; outros } \\
\text { elementos }<3 \%)\end{array}$ & $\begin{array}{l}\text { aços com teores de elementos de liga } \\
\qquad<10 \%)\end{array}$ \\
\hline Formas & todas sem reentrâncias & $\begin{array}{c}\text { principalmente } \\
\text { axissimétricas sem } \\
\text { reentrâncias }\end{array}$ & $\begin{array}{l}\text { axissimétricas são desejáveis, sem } \\
\text { reentrâncias }\end{array}$ \\
\hline Conformabilidade $(\varphi)$ & $\begin{array}{l}\text { normalmente não há } \\
\text { limite }\end{array}$ & $\begin{array}{l}\text { razão de deformação } \\
\qquad \varphi<1,6\end{array}$ & $\begin{array}{c}\text { razão de deformação } \varphi>1,6 \text { (limite } \\
\text { superior depende da composição do } \\
\text { aço e da temperatura) }\end{array}$ \\
\hline Qualidade superficial & $>100 \mu \mathrm{m}$ & $\approx 10 \mu \mathrm{m}$ & $<50 \mu \mathrm{m}$ \\
\hline $\begin{array}{l}\text { Possibilidade de } \\
\text { automação }\end{array}$ & limitada & Adequada & Vantajosa \\
\hline Tratamento superficial & não é necessário & $\begin{array}{l}\text { recozimento, } \\
\text { fosfatização }\end{array}$ & $\begin{array}{l}\text { normalmente não há tratamento } \\
\text { superficial }\end{array}$ \\
\hline Tratamento intermediário & não é necessário & $\begin{array}{l}\text { recozimento, } \\
\text { fosfatização }\end{array}$ & normalmente não é necessário \\
\hline Vida da matriz & 2000-5000 peças & $20000-50000$ peças & $10000-20000$ peças \\
\hline $\begin{array}{c}\text { Custos para } \\
\text { desenvolvimento e } \\
\text { construção de ferramentas }\end{array}$ & baixo & médio & alto \\
\hline
\end{tabular}

Este trabalho foca os fenômenos relacionados ao processo de conformação a frio, o qual ocorre no campo plástico, acima do limite de escoamento e abaixo do limite de resistência do material. Comparado com os outros processos de conformação mecânica, a conformação a frio permite obter o melhor acabamento superficial e aumentar a resistência mecânica da peça devido ao encruamento. No entanto, se por um lado ensaios mostram que acompanhando o aumento de dureza, também se elevam os limites de escoamento e de resistência, por outro lado, o encruamento reduz a ductilidade, pois parte do alongamento possível é consumido durante a conformação. Como a ductilidade diminui com o progresso da deformação, podem ocorrer falhas por ruptura antes de se atingir as dimensões finais do produto, caso a deformação seja excessiva. Para evitar este tipo de falha, os fabricantes das máquinas de conformação disponibilizam equipamentos multi- 
estágios, os quais flexibilizam o projeto do ferramental de conformação, viabilizando a fabricação de produtos com geometrias complexas sem que ocorra a ruptura de material.

\subsection{Máquinas e ferramentas de conformação a frio}

A conformação a frio é um processo para produção em série de peças, de modo que, quanto maior a quantidade de peças, mais econômica torna-se sua aplicação, de acordo com as instalações fabris disponíveis.

Entre as máquinas utilizadas no processo de conformação a frio, destacam-se a prensa hidráulica, a prensa mecânica vertical e a prensa mecânica horizontal, como apresentado na Figura 4. O estudo do efeito da rugosidade superficial nas ferramentas de conformação a frio apresentado neste trabalho focará as ferramentas provenientes das prensas mecânicas horizontais, por serem as máquinas de maior produtividade quando comparadas aos outros tipos. Além da alta produtividade, essas máquinas têm como característica a conformação progressiva do produto por meio de diversos estágios de conformação. O número de etapas de conformação dependerá do modelo da máquina a ser utilizada em cada caso. Entre os modelos de máquinas disponíveis no mercado, geralmente encontram-se máquinas de quatro, cinco e seis estágios.

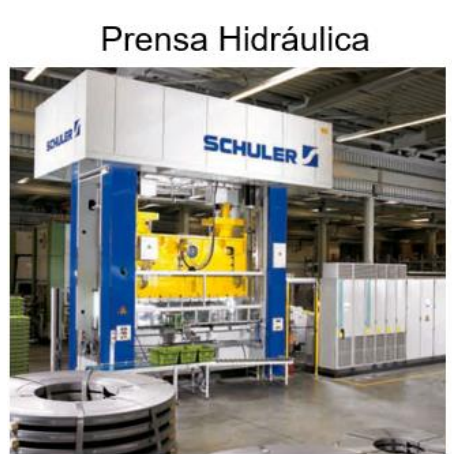

(a)

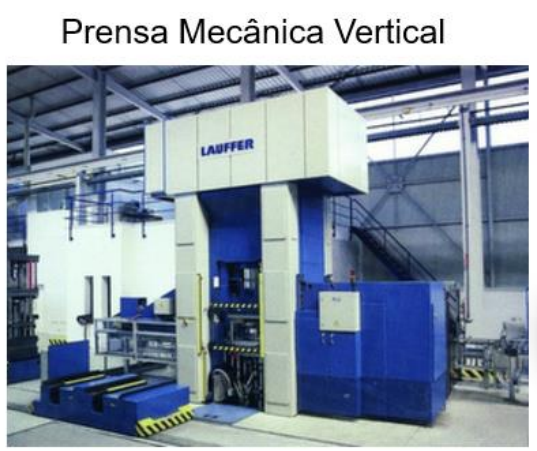

(b)

\section{Prensa Mecânica Horizontal}

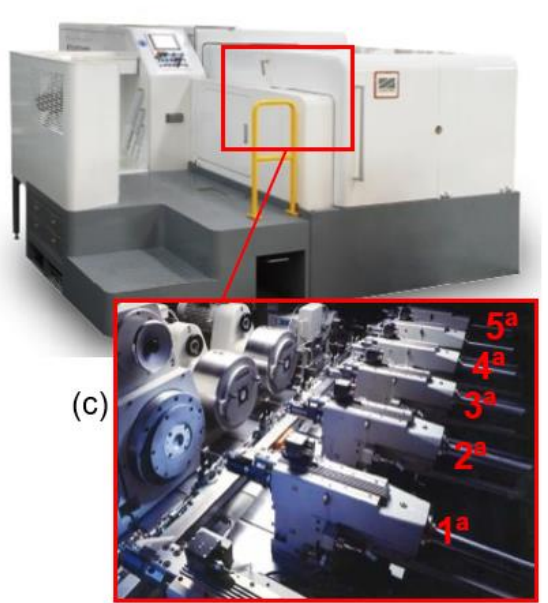

Figura 4 - Tipos de máquinas utilizadas no processo de conformação a frio. (a) Prensa hidráulica vertical; (b) Prensa mecânica vertical; (c) Prensa mecânica horizontal 
Para fabricar qualquer produto forjado, as prensas devem ser equipadas com um jogo de ferramentas especialmente desenvolvidas e fabricadas para a aplicação. As ferramentas de conformação podem ser divididas em punções, matrizes, extratores, buchas, garras e acessórios, conforme exemplificado na Figura 5.

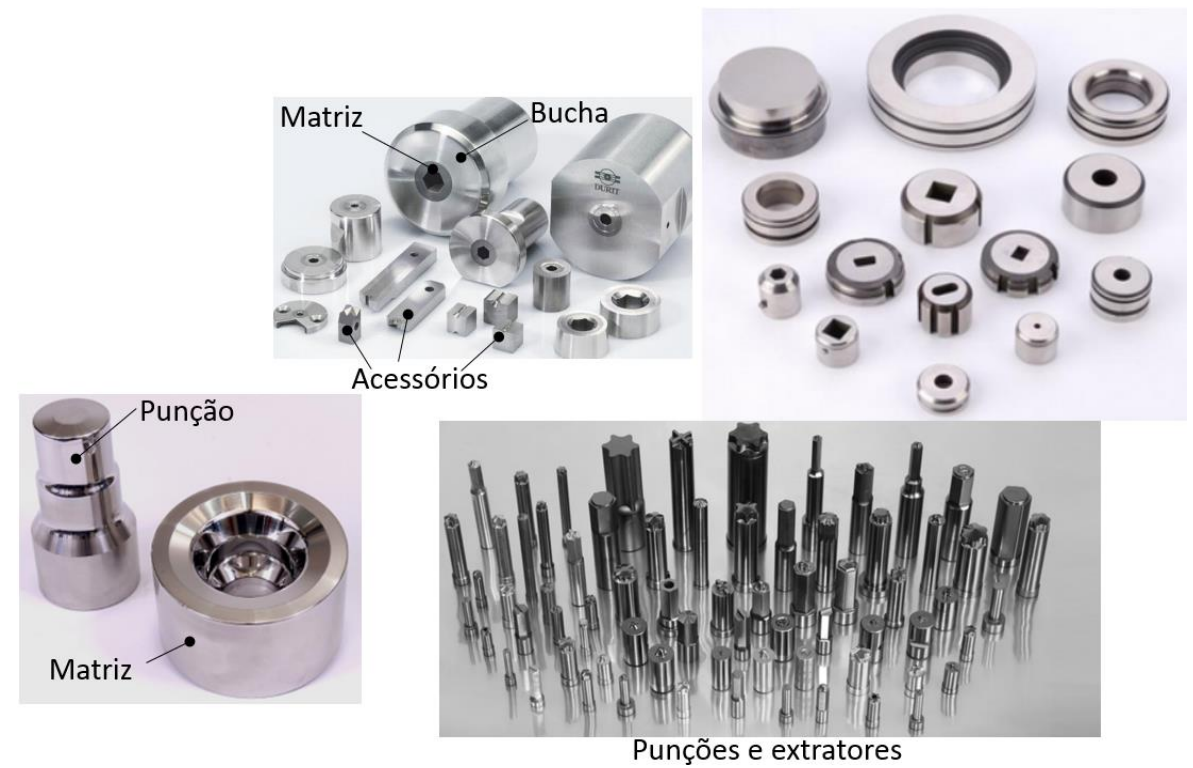

Figura 5 - Exemplos de ferramentas utilizadas no processo de conformação a frio (WRENTHAM TOOL GROUP, 2016)

Essas ferramentas necessitam de propriedades mecânicas determinadas de forma a suportar as cargas inerentes à conformação e garantir um número de ciclos admissível para o processo. Logo, é necessário o emprego de aços especialmente delineados para a aplicação. Os aços comumente utilizados na fabricação de ferramentas fazem parte de uma família de materiais denominada aços ferramenta. Estes materiais evoluíram de simples ligas de ferro e carbono, produzidas até 1868 , para ligas complexas altamente ligadas (MENDES, 2009).

Normalmente, os elementos que fazem parte dessas ligas são W, V, Cr, Mo e Mn (SCHMOLZ BICKENBACH GROUP, 2016). Dependendo das quantidades em que esses elementos são adicionados ao sistema $\mathrm{Fe}-\mathrm{C}$ e dos tratamentos térmicos dados, haverá formação de ligas com diferentes propriedades mecânicas.

Apesar das recomendações para melhor seleção de aços ferramenta, é muito comum no meio industrial escolher o material baseado na experiência prática 
que o utilizador da ferramenta tem sobre o desempenho desta, o que gera uma resistência natural à mudança.

O aço ferramenta tem custo elevado em relação aos aços convencionais de baixa liga. Portanto, quando se opta por fabricar uma determinada ferramenta com esse tipo de aço, espera-se que essa ferramenta resista ao desgaste, à fadiga e à fratura o maior número de ciclos possível para que o custo de fabricação dessa ferramenta seja diluído na produção.

Um dos fatores que motivou o presente trabalho foi observar que é comumente aceito em um ambiente industrial que a vida de ferramentas de conformação varie até uma ordem de grandeza ao decorrer de uma produção em série de um determinado forjado, onde os insumos utilizados e os parâmetros de processo são praticamente os mesmos. Por exemplo, uma determinada geometria de matriz pode produzir 100.000 peças, mas pode durar apenas 10.000 ciclos quando substituída por outra "igual". A falta de uma análise detalhada sobre situações como essa impede qualquer explicação científica para esse fenômeno indesejável, o que gerou a necessidade dessa pesquisa.

A observação prática dos operadores de máquina e dos projetistas leva a crer que quanto mais lisa a superfície da ferramenta, maior será sua durabilidade. Quando questionados do porquê dessa relação, a justificativa geralmente é dada por uma possível relação entre coeficiente de atrito e rugosidade, sendo que o desgaste (Q) aumentaria com o coeficiente de atrito $(\mu)$. O senso comum do chão de fábrica diz que quanto maior a rugosidade $\left(R_{a}\right)$, maior será o coeficiente de atrito, seja obedecendo uma função linear, exponencial ou qualquer outra função que leve à essa relação de proporcionalidade, conforme ilustrado na Figura 6.

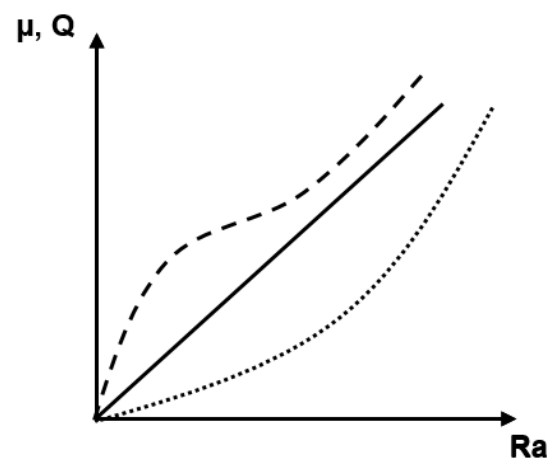

Figura 6 - Exemplos de possíveis relações entre coeficiente de atrito e rugosidade imaginadas em um ambiente fabril (Autor) 
No entanto, se alguma das curvas apresentadas na Figura 6 fosse verdadeira, como explicar o fato de que blocos padrão quando colocados em contato sob uma força normal geram uma resistência ao movimento considerável? Eles não deveriam deslizar sem resistência uma vez que quanto menor a rugosidade menor seria o coeficiente de atrito? Esse exemplo gera a necessidade de estudar o atrito em maior profundidade, antes de tentar explicar os motivos que podem levar à grande variação na vida útil das ferramentas de conformação causado por desgaste prematuro. O estudo do atrito e do desgaste necessita do entendimento da topografia das superfícies dos corpos em contato.

\subsection{Topografia e rugosidade}

O contato entre dois corpos sólidos sob ação de uma carga normal ocorre inicialmente em pequenas áreas reais de contato limitadas pela rugosidade das superfícies (HUTCHINGS, 1992). A medida que a carga normal aumenta, as superfícies ficam mais próximas e um número maior de micro áreas entram em contato. A somatória dessas áreas é denominada área real de contato $A_{r}$, a qual é responsável por transferir a carga de uma superfície para outra e por gerar a força de atrito entre elas. A área aparente de contato $A_{a}$ é medida transversalmente à carga normal aplicada e corresponde à área geométrica da seção de interesse. A área real de contato $A_{r}$ pode ser igual, maior ou menor do que a área aparente $A_{a}$. Uma representação esquemática do contato entre dois corpos sólidos está apresentada na Figura 7. Uma análise macroscópica levaria a conclusão de que as áreas aparentes e reais são iguais, porém quando a área de contato é ampliada, é possível verificar que, neste exemplo, a área real de contato é consideravelmente menor que a área aparente para a carga normal aplicada. Além disso, a área real de contato é distorcida quando os corpos apresentam movimento relativo. 


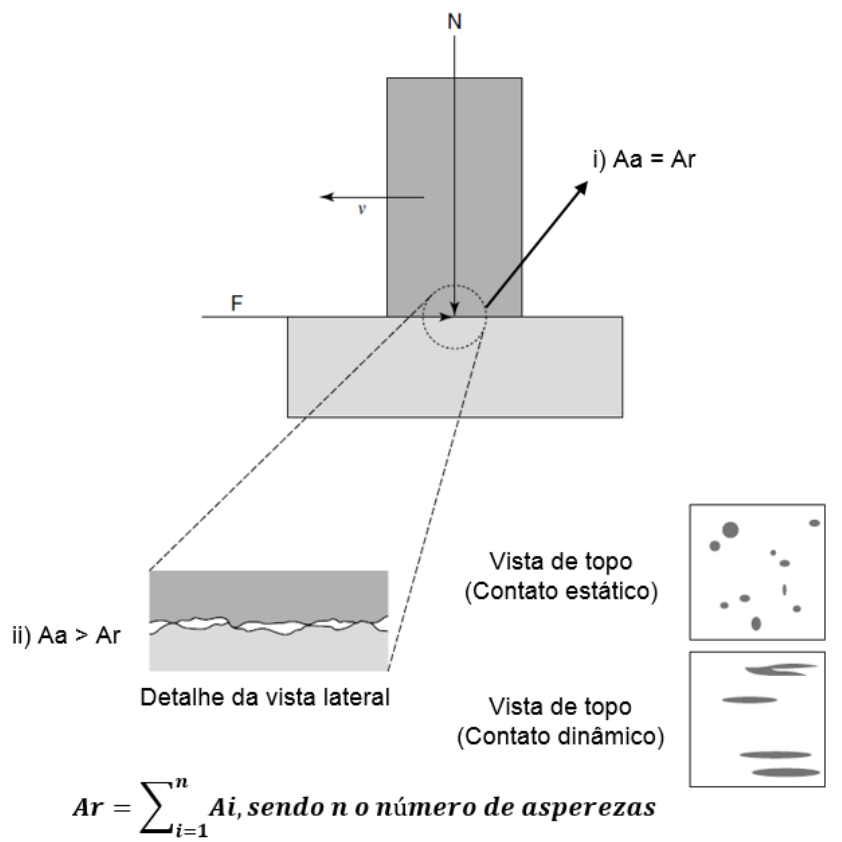

Figura 7 - Representação esquemática do contato entre dois sólidos. i) A área aparente é igual a área real na análise macroscópica. ii) $A$ área aparente é maior que a área real na análise microscópica. (Adaptado de BLAU, 2009)

A área real de contato é resultado das deformações dos pontos mais altos em contato das superfícies, os quais são conhecidos como "asperezas". As pressões de contato nessas asperezas são muito superiores às pressões de contato nominais calculadas considerando a área aparente de contato, conforme ilustrado na Figura 8. Apesar das teorias iniciais assumirem que a área real de contato deriva da deformação plástica das asperezas, atualmente é amplamente aceito que uma grande parcela do contato entre asperezas é puramente elástico (STACHOWIAK, 1993). A relação entre a área real de contato e a carga normal aplicada é crítica para o desgaste uma vez que ela afeta as relações de atrito.

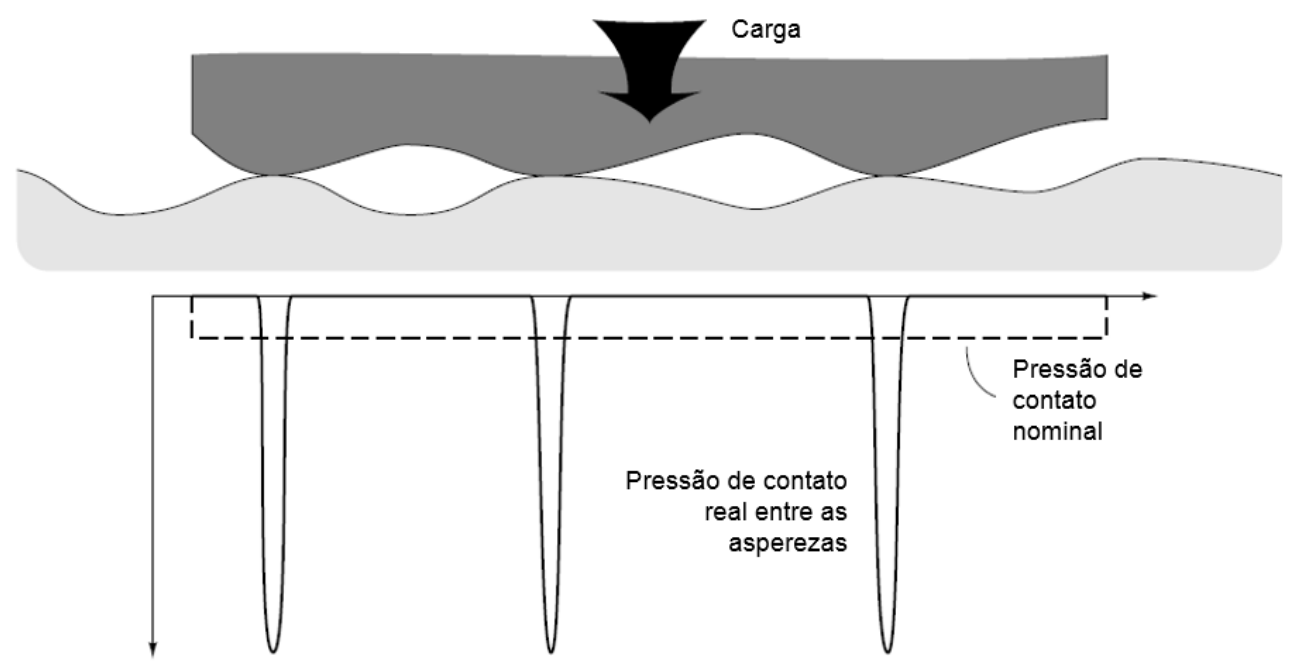

Figura 8 - Pressões de contato entre asperezas (STACHOWIAK, 1993) 
Quando estudada em uma escala suficientemente pequena, todas as superfícies dos sólidos são irregulares, até mesmo uma superfície extremamente polida de um componente de engenharia. Diversos métodos podem ser usados para analisar a topografia de um sólido, alguns envolvem a análise da superfície por meio de microscopia eletrônica ou outro método óptico, enquanto outras empregam o contato de uma ponta fina (HUTCHINGS, 1992).

Um dos métodos mais usados para avaliar a topografia de uma superfície é por meio de um perfilômetro de contato, o qual está ilustrado esquematicamente na Figura 9. Um apalpador, também conhecido como agulha, é deslizado ao longo da superfície examinada. A medida que o apalpador desliza, o seu deslocamento vertical é registrado e posteriormente convertido em um gráfico. Ainda na mesma Figura 9, a imagem (b) apresenta um perfilômetro de contato atual comumente encontrado nas fabricas para medir rugosidade, o qual é conhecido como "rugosímetro".

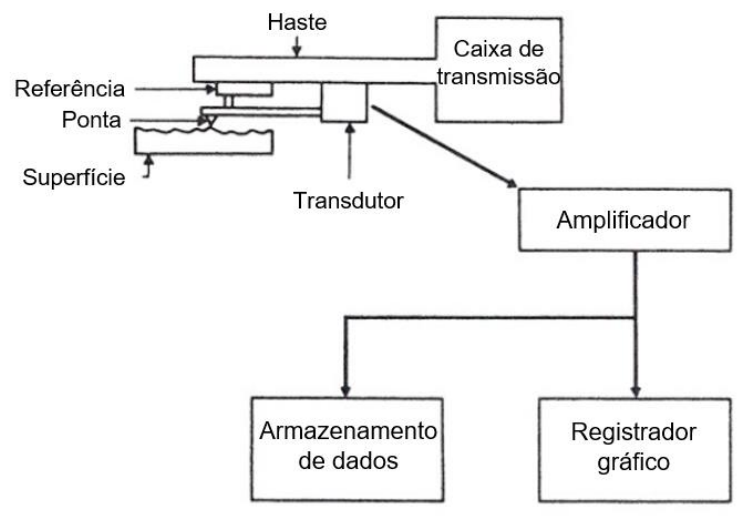

(a)

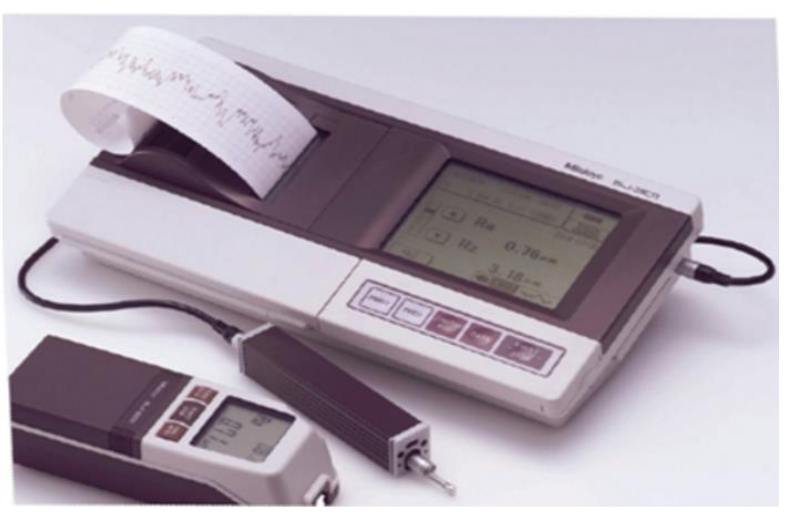

(b)

Figura 9 - (a) Princípio de operação de um perfilômetro de contato; (b) rugosímetro atual (HUTCHINGS, 1982; MITUTOYO, 2016)

A representação gráfica do perfil da superfície gerada pelo apalpador geralmente não representa a forma genuína da superfície, pois a escala vertical é comumente amplificada em relação a escala horizontal. Na Figura 10 a forma de uma superfície real é comparada com os registros de um perfilômetro da mesma superfície com fatores de aumento de 5:1 e 50:1 (HUTCHINGS, 1992). 


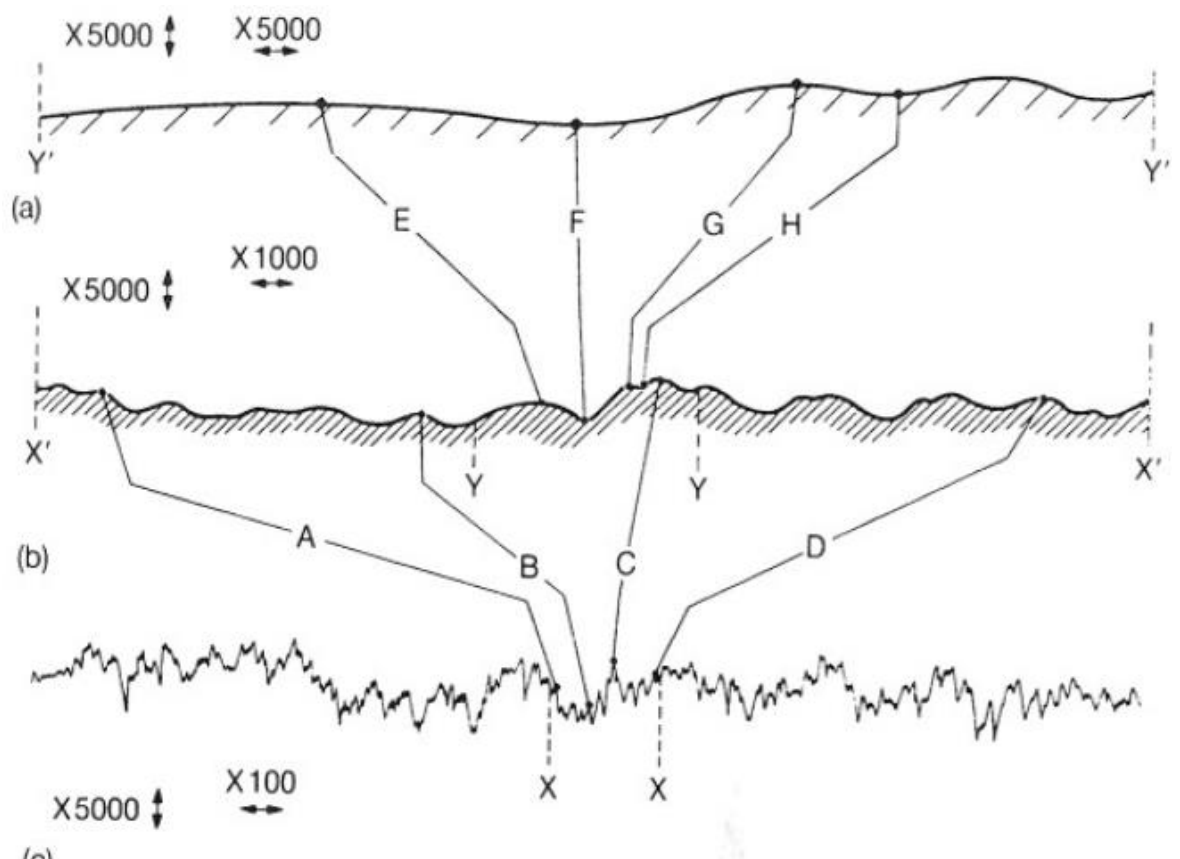

(c)

Figura 10 - (a) Perfil de uma superfície real ampliada; (b) a mesma superfície, representada pelo perfilômetro com a escala vertical cinco vezes maior que a horizontal; (c) assim como (b), mas com uma escala vertical cinquenta vezes maior que a horizontal (HUTCHINGS, 1992)

Em uma caracterização bidimensional de uma superfície, que é o procedimento mais comum utilizado, é conveniente diferenciar entre rugosidade, como sendo as pequenas irregularidades de uma superfície, e ondulação, que significa os erros de forma de uma superfície real comparada com uma superfície ideal. A Figura 11 ilustra a diferença entre rugosidade, ondulação e perfil nominal de uma superfície.

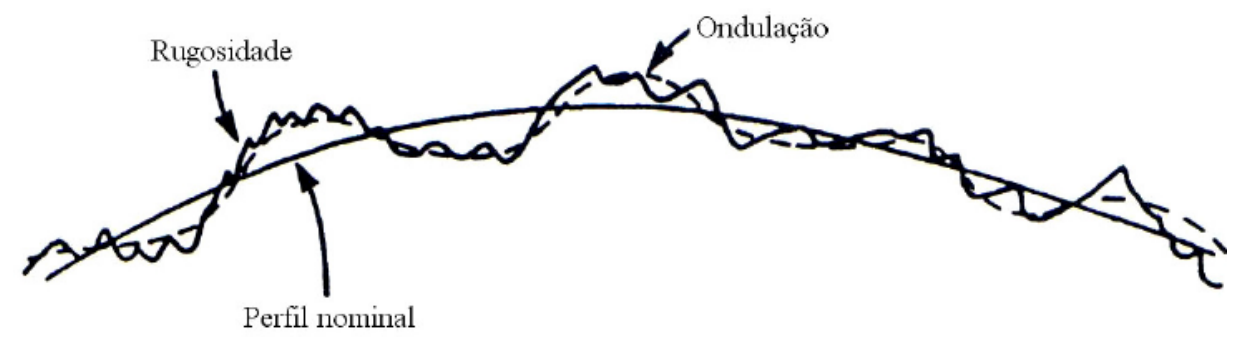

Figura 11 - Rugosidade, ondulação e perfil ideal de uma superfície (WHITESTONE, 1994)

Uma limitação inevitável do método de perfilometria de contato resulta da dimensão do apalpador. Por questões físicas e de resistência, os apalpadores apresentam dimensões finitas, as quais incluem raios e ângulos mínimos conforme ilustrado na Figura 12. 


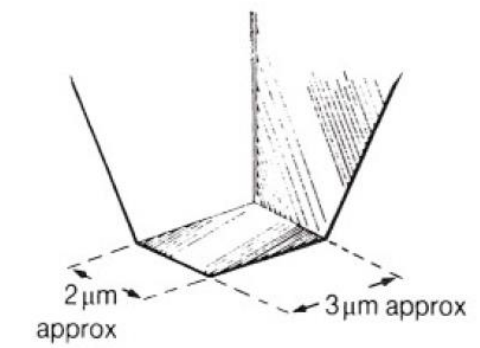

(a)

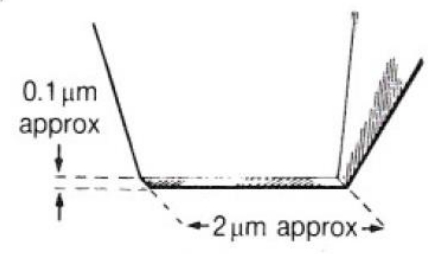

(b)

Figura 12 - (a) Uma ponta padrão de apalpador utilizada por perfilômetro de contato; (b) uma ponta mais fina utilizada para analisar superfícies mais refinadas (HUTCHINGS, 1992)

Dependendo da dimensão do apalpador, a análise da superfície pode ser distorcida pela leitura do perfilômetro, uma vez que a ponta do apalpador pode não chegar no fundo dos vales e alterar a curvatura dos picos, conforme ilustrado na Figura 13. As distorções geradas pelo tamanho da ponta do apalpador podem comprometer a análise de rugosidade de uma superfície.
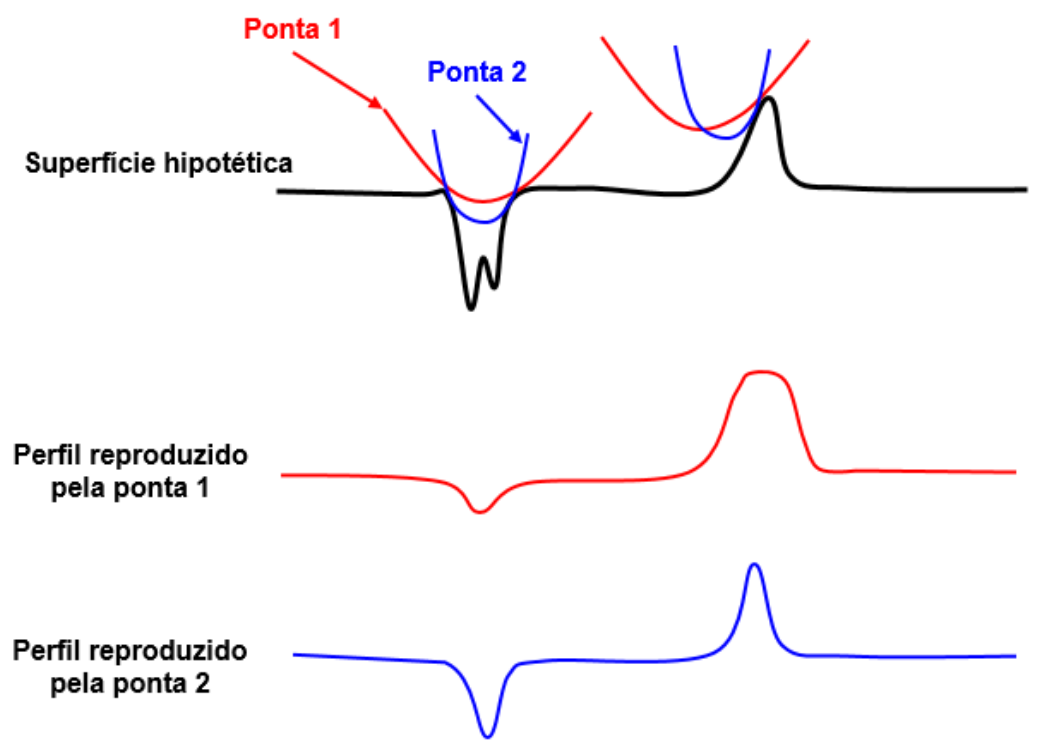

Figura 13 - Influência do tamanho da ponta do apalpador na leitura de uma mesma superfície

Diversas técnicas e parâmetros foram desenvolvidos para caracterizar a topografia de superfícies. As mais conhecidas contemplam parâmetros estatísticos para quantificar um valor de rugosidade. Na maioria das aplicações de engenharia, o parâmetro mais utilizado é o da rugosidade média, $R_{a}$. $O R_{a}$ representa a média dos 
picos e vales a partir de uma linha média para um dado comprimento analisado. $O$ efeito de um único pico espúrio é minimizado no valor final de $R_{a}$. Logo, devido à média aplicada no cálculo, uma desvantagem desse parâmetro é que superfícies completamente diferentes podem resultar em valores de $R_{a}$ idênticos. Além do $R_{a}$, também são utilizados os parâmetros de raiz quadrada da rugosidade média $R_{q}$ ou RMS, o valor médio da máxima altura entre pico e vale $R_{t}$, a média de dez pontos $\mathrm{R}_{z}$, e outros parâmetros resumidos na Tabela 2 .

Tabela 2 - Parâmetros bidimensionais de rugosidade (STACHOWIAK, 1993)

\begin{tabular}{|c|c|c|}
\hline $\begin{array}{l}\text { Rugosidade média } \\
\left(\mathbf{R}_{\mathrm{a}} \text { ou CLA) }\right.\end{array}$ & $\mathbf{R}_{\mathrm{a}}=\frac{\mathbf{1}}{\mathbf{L}} \int_{0}^{\mathrm{L}}|\mathbf{z}| \mathbf{d x}$ & $\underset{2}{|\mathbf{z}|}$ \\
\hline $\begin{array}{l}\text { Rugosidade média } \\
\text { quadrática } \\
\text { ( } \mathbf{R}_{\mathrm{q}} \text { ou RMS) }\end{array}$ & $R_{q}=\sqrt{\frac{1}{L} \int_{0}^{L} z^{2} d x}$ & ${ }_{A} \mathbf{Z}$ \\
\hline $\begin{array}{l}\text { Rugosidade total } \\
\left(\mathbf{R}_{\mathrm{t}}\right)\end{array}$ & $\begin{array}{l}\text { Maior altura de pico à } \\
\text { vale entre cinco } \\
\text { períodos subsequentes } \\
\mathbf{R}_{\mathrm{t}}=\frac{1}{5} \sum_{\mathrm{i}=1}^{5} \mathbf{R}_{\text {max }_{\mathrm{i}}}\end{array}$ & 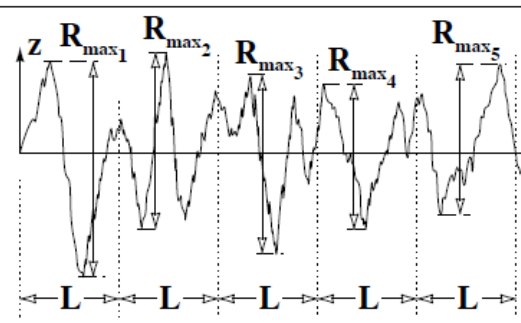 \\
\hline $\begin{array}{l}\text { Média de dez } \\
\text { pontos } \\
\left(\mathbf{R}_{\mathbf{z}}\right)\end{array}$ & $\begin{array}{l}\text { Média dos cinco picos } \\
\text { mais altos e dos cinco } \\
\text { vales mais profundos } \\
\text { em um dado } \\
\text { comprimento amostral } \\
\qquad \mathbf{R}_{\mathbf{z}}=\frac{\mathbf{p}_{1}+\ldots+\mathbf{p}_{5}+}{\mathbf{\mathbf { v } _ { 1 } + \ldots + \mathbf { v } _ { 5 }}}\end{array}$ & Assessment length $\longrightarrow$ \\
\hline
\end{tabular}

Na Tabela 2, "L" é o comprimento total da amostra e "z" é altura do perfil ao longo do comprimento " $x$ ".

Analogamente aos parâmetros bidimensionais, os parâmetros tridimensionais para caracterização superficial são utilizados para quantificar a rugosidade de uma superfície, relativa a uma área medida. A principal vantagem dos parâmetros tridimensionais é que eles conseguem representar, de maneira mais detalhada, as superfícies que sofreram desgaste. Neste caso, uma análise 
bidimensional de uma superfície desgastada levaria a infinitos valores de $R_{a}, R_{q} e$ $\mathrm{R}_{z}$, uma vez que a área desgastada geralmente apresenta um caráter aleatório de picos e vales, o que impossibilita determinar um valor único para os parâmetros bidimensionais. A Figura 14 apresenta um perfilômetro óptico utilizado para analisar a topografia de uma superfície em três dimensões. Seu funcionamento é baseado em dois feixes de luz, refletidos da superfície examinada e de um plano perfeito de referência, os quais criam franjas que são registradas por fotodiodos conectados a um microprocessador. Pequenos desvios da superfície perfeita de referência causam mudanças no padrão das franjas, que por sua vez alteram a distribuição de alturas da superfície examinada as quais são registradas pelo processador (HUTCHINGS, 1992). Em relação ao perfilômetro de contato, o perfilômetro óptico apresenta as seguintes vantagens: i) Capacidade de examinar superfícies muito sensíveis sem danificá-las; ii) Possibilidade de extrair parâmetros bidimensionais em qualquer seção da área analisada; iii) Capacidade de analisar a topografia de uma área desgastada; iv) Capacidade de analisar regiões que a agulha do perfilômetro de contato não consegue tocar devido a sua dimensão física. Em contrapartida, a técnica mais antiga ainda é a mais utilizada em ambientes industriais por apresentar as seguintes vantagens: i) Custo mais acessível; ii) Praticidade e facilidade de movimentação para realizar medições em campo; iii) A maioria das normas para quantificar acabamento superficial referem-se a parâmetros bidimensionais; iv) 0 método não é sensível à refletância ou coloração da superfície examinada (DELEANU, 2012).
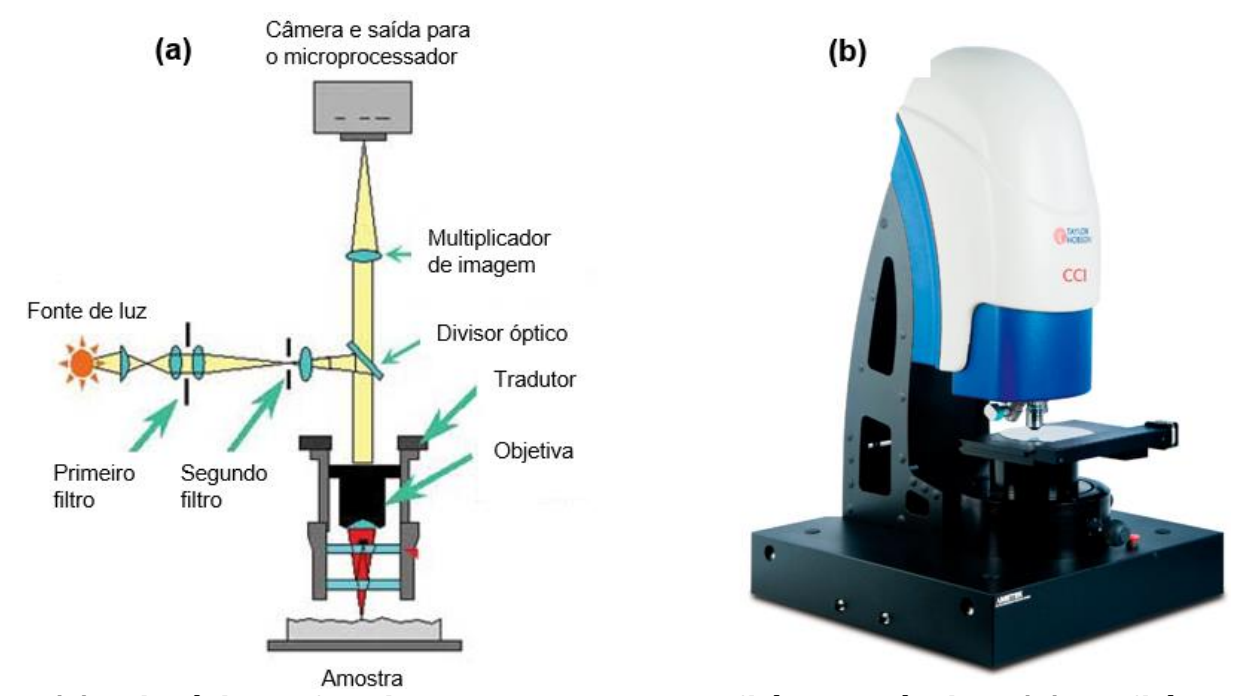

Figura 14 - (a) Princípio de funcionamento de um perfilômetro óptico; (b) Perfilômetro óptico atual (Adaptado de TAYLOR HOBSON, 2016) 
Os parâmetros tridimensionais mais utilizados são $S_{a}, S_{q}, S_{s k}, S_{k u}, S_{p}, S_{v} e$ Sz. Os parâmetros a serem analisados dependem da aplicação a qual a superfície analisada é submetida.

Os parâmetros $S_{a}$ e $S_{q}$ são, respectivamente, a rugosidade média e a raiz quadrada da rugosidade média de uma determinada área analisada. Esses parâmetros tridimensionais são análogos aos parâmetros bidimensionais $R_{a}$ e $R_{q}$. Matematicamente, $S_{a}$ e $S_{q}$ são calculados da seguinte forma:

$$
\begin{aligned}
& S_{a}=\iint|Z(x, y)| \partial x \partial y \\
& S_{q}=\sqrt{\iint[Z(x, y)]^{2} \partial x \partial y}
\end{aligned}
$$

Os valores de Sa e Sq serão idênticos aos valores de Ra e Rq quando uma mesma superfície de textura periódica é analisada, como em um caso de uma superfície intacta após um processo de usinagem. No entanto, quando essa superfície é submetida ao desgaste, os valores dos parâmetros tridimensionais e bidimensionais diferem substancialmente. A Figura 15 ilustra a relação entre os parâmetros $S_{a}$ e $S_{q}$ com os parâmetros $R_{a}$ e $R_{q}$ para duas condições de superfície.

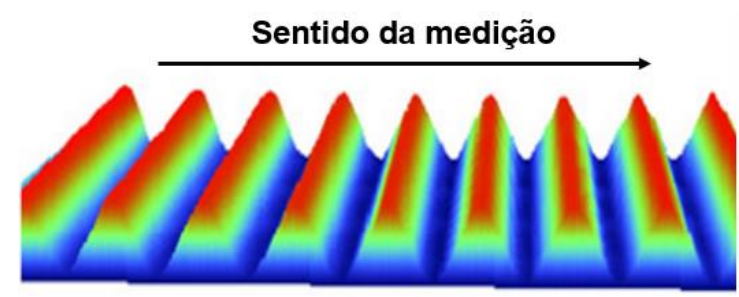

(a) Superfície periódica: $\mathrm{Sa}=\mathrm{Ra}$ e $\mathrm{Sq}=\mathrm{Rq}$

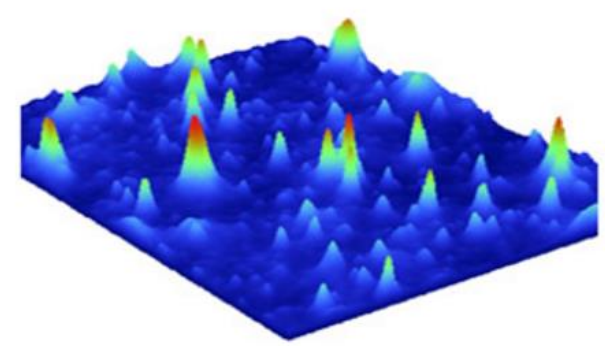

(b) Superfície aleatória: $\mathrm{Sa} \neq \mathrm{Ra}$ e $\mathrm{Sq} \neq \mathrm{Rq}$

Figura 15 - (a) superfície com textura periódica; (b) superfície com textura aleatória (Adaptado de MICHIGAN METROLOGY, LLC) 
A Tabela 3 resume os parâmetros tridimensionais de amplitude mais utilizados para analisar a rugosidade de uma superfície. Além dos parâmetros de amplitude, existem parâmetros híbridos, como o $S_{c s}$, que representa a curvatura média das extremidades da superfície analisada. Os parâmetros funcionais $S_{m}, S_{c} e$ $\mathrm{S}_{\mathrm{v}}$, os quais representam o volume de material relativo à uma área analisada, não serão utilizados no presente trabalho.

Tabela 3 - Parâmetros tridimensionais de rugosidade (Adaptado de OLYMPUS)

\begin{tabular}{|c|c|c|}
\hline Rugosidade média $\left(\mathrm{S}_{\mathrm{a}}\right)$ & $S_{a}=\iint|Z(x, y)| \partial x \partial y$ & $\begin{array}{l}\text { Parâmetro incapaz de diferenciar entre } \\
\text { pico e vale. Superfícies completamente } \\
\text { distintas podem apresentar o mesmo valor } \\
\text { de } S_{a} \text {. Porém, uma vez que a superfície } \\
\text { apresenta uma textura com padrão } \\
\text { periódico, por exemplo, superfícies } \\
\text { usinadas, o emprego do } S_{a} \text { é } \\
\text { recomendável. }\end{array}$ \\
\hline $\begin{array}{l}\text { Rugosidade media } \\
\text { quadrática }\left(\mathrm{S}_{\mathrm{q}}\right)\end{array}$ & $S_{q}=\sqrt{\iint[Z(x, y)]^{2} \partial x \partial y}$ & $\begin{array}{l}\text { Idem } S_{a} \text {. As aplicações mais comuns para } \\
\text { o } S_{q} \text { envolvem algum tipo de superfície } \\
\text { óptica. }\end{array}$ \\
\hline Assimetria $\left(\mathrm{S}_{\mathrm{sk}}\right)$ & $S_{s k}=\frac{1}{S_{q}^{3}} \iint[Z(x, y)]^{3} \partial x \partial y$ & $\begin{array}{l}\text { Avalia o grau de simetria das alturas de } \\
\text { uma superfície sobre um plano médio. } O \\
\text { sinal de } S_{s k} \text { indica predominância de picos } \\
\left(S_{s k}>0\right) \text { ou vales }\left(S_{s k}<0\right) \text { da superfície. }\end{array}$ \\
\hline Curtose (Sku) & $S_{k u}=\frac{1}{S_{q}^{4}} \iint[Z(x, y)]^{4} \partial x \partial y$ & $\begin{array}{l}\text { Avalia a curtose de uma superfície, ou } \\
\text { seja, a presença }\left(S_{k u}>3,0\right) \text { ou ausência } \\
\text { (Sku<3,0) de picos ou vales extremos de } \\
\text { maneira desordenada na superfície. } \\
\text { Geralmente, é utilizado na especificação } \\
\text { de processos como o brunimento. }\end{array}$ \\
\hline $\begin{array}{l}\text { Máxima altura de pico } \\
\left(\mathrm{S}_{\mathrm{p}}\right)\end{array}$ & $S_{p}=\max (Z(x, y))$ & $\begin{array}{l}\text { Quantifica a altura do pico mais alto. } \\
\text { Geralmente é especificado em superfícies } \\
\text { utilizadas em contato mecânico com } \\
\text { deslizamento. }\end{array}$ \\
\hline $\begin{array}{l}\text { Máxima profundidade de } \\
\text { vale }\left(S_{v}\right)\end{array}$ & $S_{v}=\min (Z(x, y))$ & $\begin{array}{l}\text { Quantifica a profundidade do vale mais } \\
\text { profundo. É utilizado quando a } \\
\text { profundidade do vale é importante para } \\
\text { retenção de fluido e é comumente utilizado } \\
\text { em aplicações de resistência à corrosão. }\end{array}$ \\
\hline $\begin{array}{l}\text { Altura máxima da } \\
\text { superfície }\left(\mathrm{S}_{\mathrm{z}}\right)\end{array}$ & $S_{q}=S_{p}+S_{v}$ & $\begin{array}{l}\text { Representa a diferença entre o pico mais } \\
\text { alto e o vale mais profundo. Aplicações } \\
\text { típicas de } S_{z} \text { incluem retentores e } \\
\text { superfícies após tratamento superficial. }\end{array}$ \\
\hline
\end{tabular}


A tecnologia utilizada para determinar os parâmetros tridimensionais de rugosidade deriva de métodos ópticos e sem contato mecânico. No presente trabalho, um perfilômetro óptico 3D foi utilizado para acessar o comportamento das superfícies das ferramentas de conformação novas e usadas.

\subsection{Atrito}

O comportamento do atrito tem sido objeto de estudo por mais de meio milênio. Um dos exemplos mais comentados sobre o assunto é o desenho egípcio encontrado na tumba de Djehutihotep, datado de 1880 AC, apresentado na Figura 16, o qual mostra um colosso sendo puxado por diversas fileiras de escravos (BLAU, 2009). Na frente do trenó de madeira que a estátua repousa, um dos escravos é flagrado derramando um líquido, presumidamente banha animal (uma vez que a forma do vaso não é típica daqueles usados para água na época), nos rodízios usados para transportar o grande trenó. Acredita-se que o líquido derramado era utilizado para reduzir o coeficiente de atrito entre os rodízios e o solo de forma a permitir com que os escravos transportassem o colosso (ACERO, 2015).

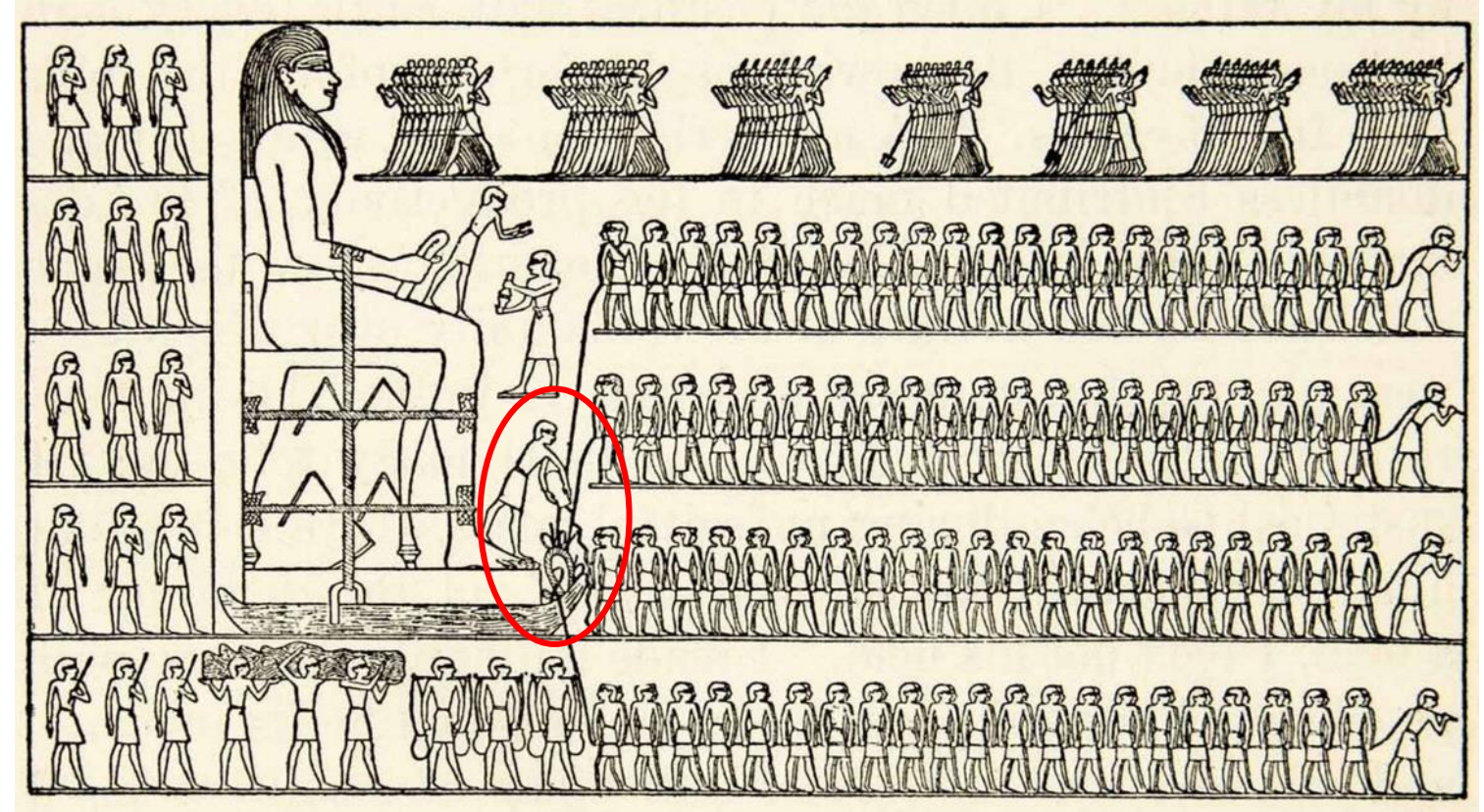

Figura 16 - Desenho encontrado na tumba de Djehutihotep mostrando um colosso com cerca de vinte e dois pés de altura sendo transportado sobre um trenó de madeira por 172 homens (PHYS.ORG, 2016)

Leonardo da Vinci estudou o comportamento do atrito por mais de vinte anos. Seus rascunhos, mostrados na Figura 17, incluíam diversos tipos de aparatos 
que ele mesmo projetou para estudar o atrito por deslizamento em contatos com e sem lubrificantes. Apesar da palavra "tribologia" ter sido definida quase 450 anos após a morte de Leonardo, seus rascunhos não deixam dúvidas de que ele era muito familiar com os conceitos básicos de tribologia ${ }^{2}$, atrito, lubrificação e desgaste. Por essas razões, Leonardo da Vinci é considerado o pioneiro da tribologia (HUTCHINGS, 2016).
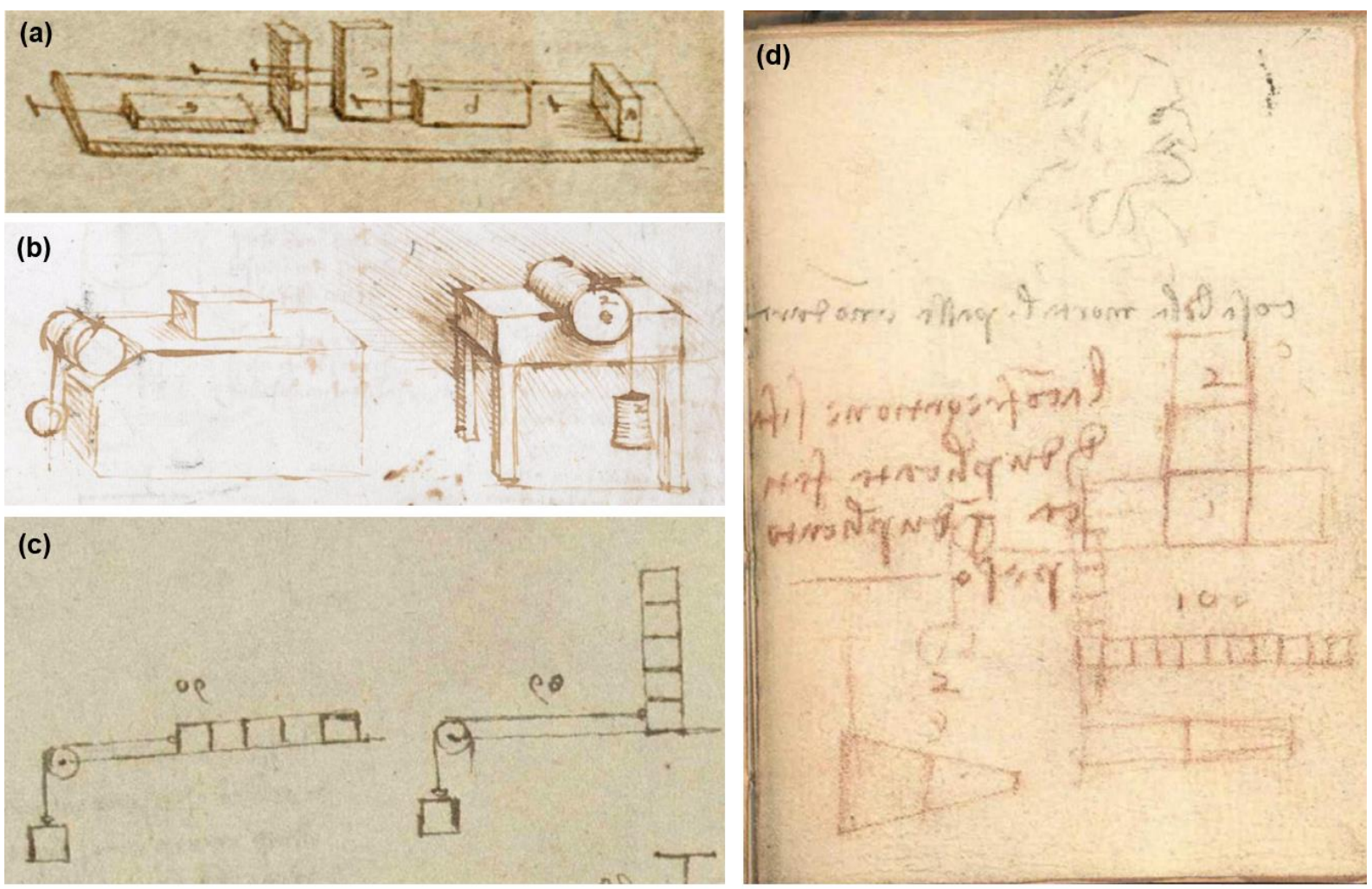

(b)
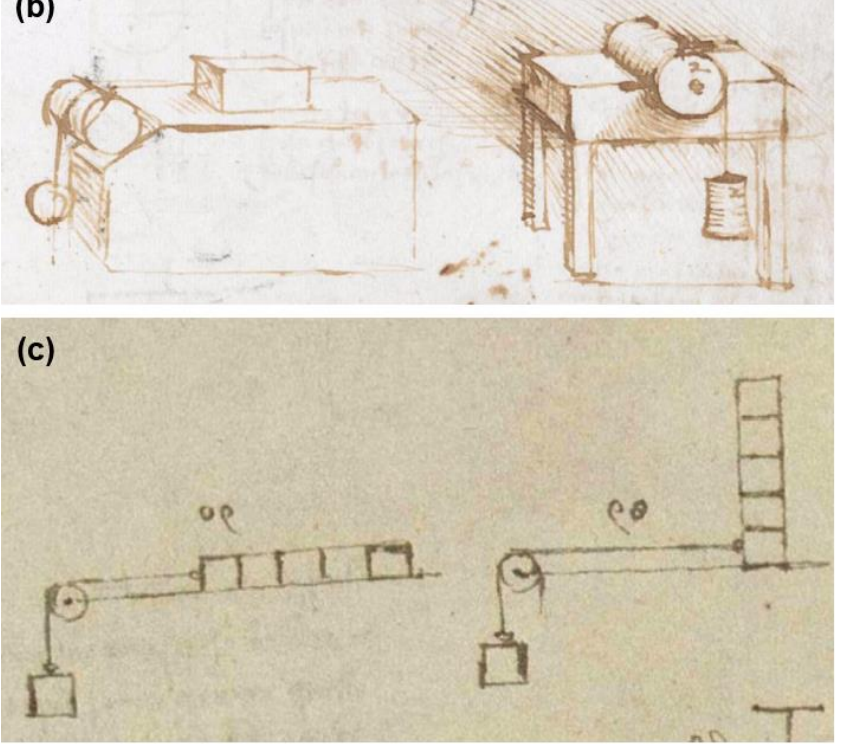

Figura 17 - Rascunhos de Leonardo da Vinci: (a) Blocos similares em diversas orientações sendo puxados; (b) Bloco e cilindro escorregando em um plano horizontal com o auxilio de um

barril e cordas; (c) estudo do efeito da pressão de contato na área real de contato e (d) primeira anotação de Leonardo sobre as leis do atrito (Codex Atlanticus e Codex Arundel apud HUTCHINGS, 2016)

Em 1699, o francês Guillaume Amontons (1663 - 1705) fez uma releitura dos trabalhos de da Vinci e elaborou as duas leis clássicas do atrito (HUTCHINGS, 2016; SEIREG, 1998):

a) A força de atrito é diretamente proporcional à carga aplicada.

b) A força de atrito é independente da área aparente de contato.

${ }^{2}$ Tribologia é a ciência que estuda o desgaste e será tratada na seção 3.4 
Atualmente, sabe-se que essas "leis" não são sempre seguidas, especialmente quando o escorregamento acontece em ambientes extremos como altas velocidades ou com variação de carga normal muito grande. Diversos autores contribuíram para o entendimento do atrito. Entre eles, Robert Hooke (1635 - 1703) analisou o atrito por rolamento e identificou dois componentes: (a) escoamento da pista durante o rolamento e (b) adesão das partes. Leonhard Euler (1707 - 1783) esclareceu a diferença entre atrito estático e dinâmico e implementou o uso da letra grega mu $(\mu)$ para "coeficiente de atrito". Charles August Coulomb (1736 - 1806) investigou o efeito da natureza dos materiais em contato, a extensão da área de contato, a carga normal e o tempo que as superfícies permanecem em contato e em repouso (HUTCHINGS, 1992). O efeito dessas e de outras variáveis é objeto de estudo atualmente, sendo que isolar uma única variável em um ensaio de atrito é bastante improvável. Por exemplo, se aumentarmos a carga normal, a taxa de desgaste pode aumentar; se aumentarmos a velocidade de deslizamento, a temperatura na interface pode aumentar também. Percebe-se que isolar essas variáveis sinergéticas é um grande desafio para a ciência.

A Tabela 4 apresenta os fatores que influenciam o coeficiente de atrito. A importância relativa de cada fator depende da particularidade de cada tribossistema. Analisando a quantidade de variáveis, torna-se lógico concluir que o coeficiente de atrito não é uma propriedade intrínseca ao material, mas sim uma propriedade do sistema.

O efeito da rugosidade superficial no atrito ainda é objeto de estudo atualmente. Em alguns tribossistemas existe uma relação direta entre atrito e rugosidade inicial das superfícies em contato. Em outros casos, o desgaste altera muito rapidamente a topografia das superfícies de forma que qualquer tentativa de relacionar rugosidade com coeficiente de atrito se torna inapropriada (SEDLACEK, 2009). 
Tabela 4 - Fatores que influenciam o coeficiente de atrito de acordo com as circunstâncias (Traduzido de BLAU, 2009)

\begin{tabular}{ll}
\hline Categoria & Fator \\
Mecânica & Geometria de contato: Macro, micro, nano \\
& Distribuição de carga e pressão de contato em diversas escalas \\
& Histórico de carregamento \\
& Dinâmica do sistema: Vibração, rigidez, amortecimento, histerese, \\
& Tipo de movimento e perfil de velocidade \\
Material & Afinidade dos materiais \\
& Composição química e pureza dos materiais \\
& Características adesivas \\
& Microestrutura e tamanho das características microestuturais em \\
& relação ao tamanho do tribocontato \\
& Propriedades elasto-plásticas dos materiais \\
& Gradiente de propriedade na região limítrofe de contato \\
& Propriedades termo-físicas: Condutividade térmica, expansão \\
& térmica, etc. \\
& Acabamento da superfície \\
& Tensão residual na região limítrofe de contato \\
& Aquecimento por atrito \\
& Aquecimento de fontes externas \\
Efeitos térmicostabilidade termo-elástica \\
Transformação de fase induzido por calor: Amolecimento e \\
derretimento \\
Ativação triboquímica \\
Choque térmico durante o carregamento cíclico \\
Quantidade \\
Regime de lubrificação \\
Propriedade do lubrificante \\
Composição do lubrificante \\
Envelhecimento do lubrificante \\
Pureza do lubrificante \\
Umidade relativa \\
Reatividade da superfície \\
Limpeza \\
Composição do meio circunvizinho \\
Tribopolimerização \\
Formação de polímeros de atrito \\
Filmes de óxido \\
Transferência e formação de partículas \\
Mecânica e lubrificação da camada triboformada \\
Concentração e aglomeração de partículas de desgaste \\
Tamanho, forma e morfologia das partículas \\
Contaminantes externos \\
Movimentação do terceiro corpo para dentro ou para fora do contato \\
\hline
\end{tabular}


Blau (2009) resume que o acabamento superficial inicial influenciará no atrito se:

a) A pressão de contato for pequena suficiente para evitar a perda da geometria original por desgaste;

b) A resistência ao desgaste dos materiais em escorregamento é alta suficiente para preservar as características superficiais após escorregamentos prolongados;

c) $\mathrm{Na}$ presença de líquido, o regime de lubrificação for afetado pela rugosidade superficial;

d) A micro geometria da superfície apresentar características que retém as partículas desprendidas, as quais poderiam acumular e afetar o atrito.

De acordo com Blau (2009), o acabamento inicial da superfície tem pouca influência se a pressão de contato for alta suficiente para destruí-la ou se a transferência de material entre os corpos ocorrer. No entanto, diversas empresas do setor de conformação, onde grandes pressões de contato são inerentes ao processo, afirmam por meio de observações práticas que existe uma diferença substancial na vida útil das ferramentas em função do grau de acabamento superficial inicial (ENGEL et al., 2011).

Um exemplo de relação entre coeficiente de atrito e rugosidade está apresentado na Figura 18. Nas superfícies muito lisas o atrito tende a ser alto devido ao aumento excessivo da área real de contato, enquanto nas superfícies muito rugosas o atrito é alto porque a força necessária para movimentar relativamente uma superfície contra as asperezas da outra é alta. Na faixa intermediária de rugosidade, que geralmente é utilizada nas aplicações de engenharia, o atrito é mínimo e praticamente independe da rugosidade. Uma situação excepcional em que uma superfície mais rugosa gera maior atrito do que uma mais lisa, é quando um corpo duro desliza sobre um corpo mais mole. Neste caso, as asperezas do corpo mais duro "cavam" o material mais mole, e quando o escorregamento ocorre, é necessário cisalhar uma área maior do material mais mole do que a área aparente (RABINOWICZ, 1995). 


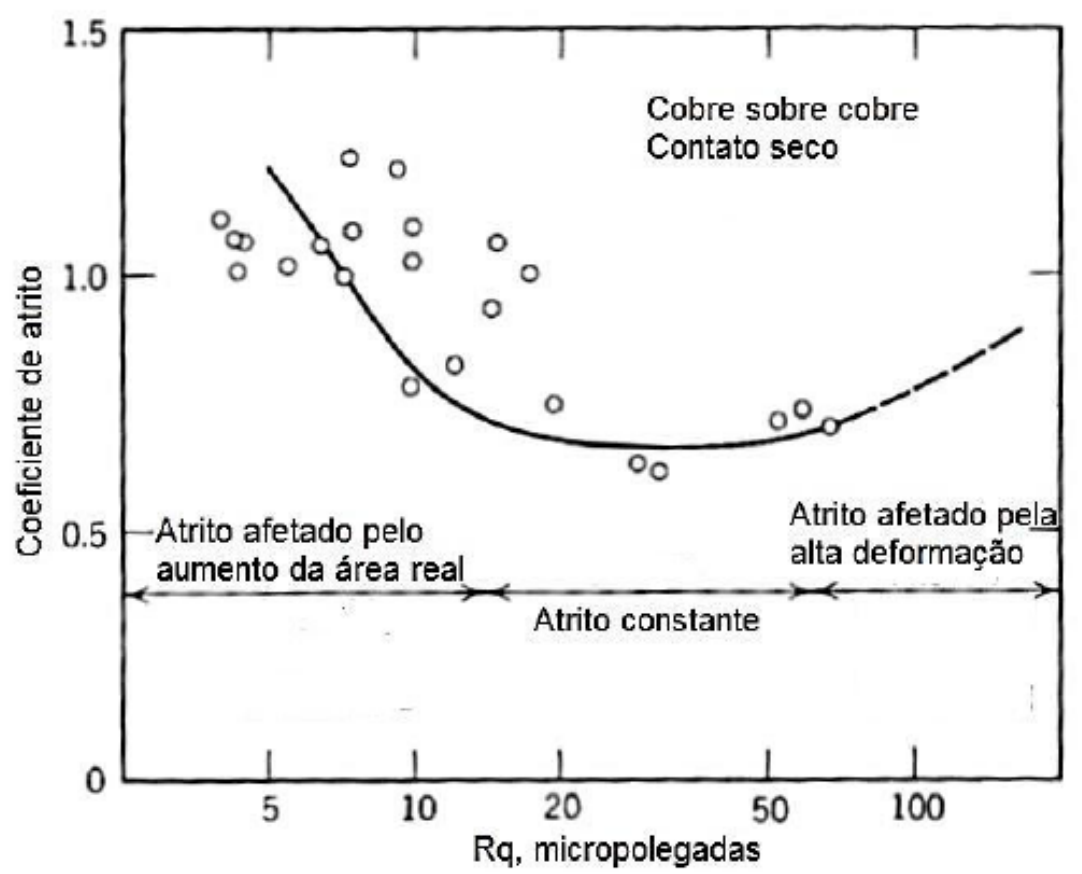

Figura 18 - A relação entre coeficiente de atrito e rugosidade mostra uma região de rampa negativa causada por crescimento de junção excessivo e uma região positiva causada pelo intertravamento das asperezas. Entre elas, $O$ atrito independe da rugosidade (Adaptado de RABINOWICZ, 1995)

A relação apresentada na Figura 18 foi obtida para dois corpos de cobre em contato não lubrificado. Devido à sua justificativa física, a explicação apresentada por Rabinowicz (1995) pode ser aplicável para outros tipos de materiais, por exemplo, corpos de aço em movimento relativo. É evidente que a forma da curva pode variar de acordo com o sistema. Porém, se existe uma faixa de rugosidade onde o atrito é mínimo e qualquer rugosidade menor do que essa faixa só levaria à um aumento da resistência ao movimento, é lógico pensar que a partir de certo ponto não adianta investir em processos que agregam custo na fabricação dos corpos para deixá-los mais lisos, se o efeito é o contrário do desejado. Via de regra, para deixar uma superfície mais lisa é necessário gastar mais dinheiro com retíficas e polimento, por exemplo. Assumindo que exista uma relação entre o coeficiente de atrito e o desgaste das ferramentas durante o processo de conformação, é possível que exista uma faixa de rugosidade onde o desgaste será mínimo dependendo do tipo de lubrificação e condição de processo. A relação entre rugosidade e desgaste das ferramentas será discutida na seção 3.6. Essa discussão exige o entendimento dos mecanismos de desgaste e condições de topografia que serão apresentados a seguir. 


\subsection{Desgaste}

O significado comum e perceptível do desgaste pode ser resumido em: modificações da forma original de um corpo por ação do tempo ou frequência de contato com outro corpo. Esta percepção é maior à medida que o tempo passa, pois essa variável é diretamente proporcional à intensidade das alterações da forma original. Outras definições de desgaste são (UEHARA, 2005):

a) "Perda de material que ocorre quando uma superfície rola, desliza ou impacta sobre a outra" (BAYER, 1972).

b) "Modificações indesejáveis e cumulativas em dimensões, pela gradual remoção de partículas devido ao contato entre superfícies em movimento" (COLLINS, 1993).

c) "Dano progressivo, que envolve a perda de material, que ocorre sobre a superfície de um componente como resultado do movimento relativo a um contra-corpo" (WILLIAMS, 1994).

A Figura 19 apresenta alguns exemplos de superfícies que sofreram desgaste e que atendem as três definições de Bayer (1993), Collins (1993) e Williams (1994).

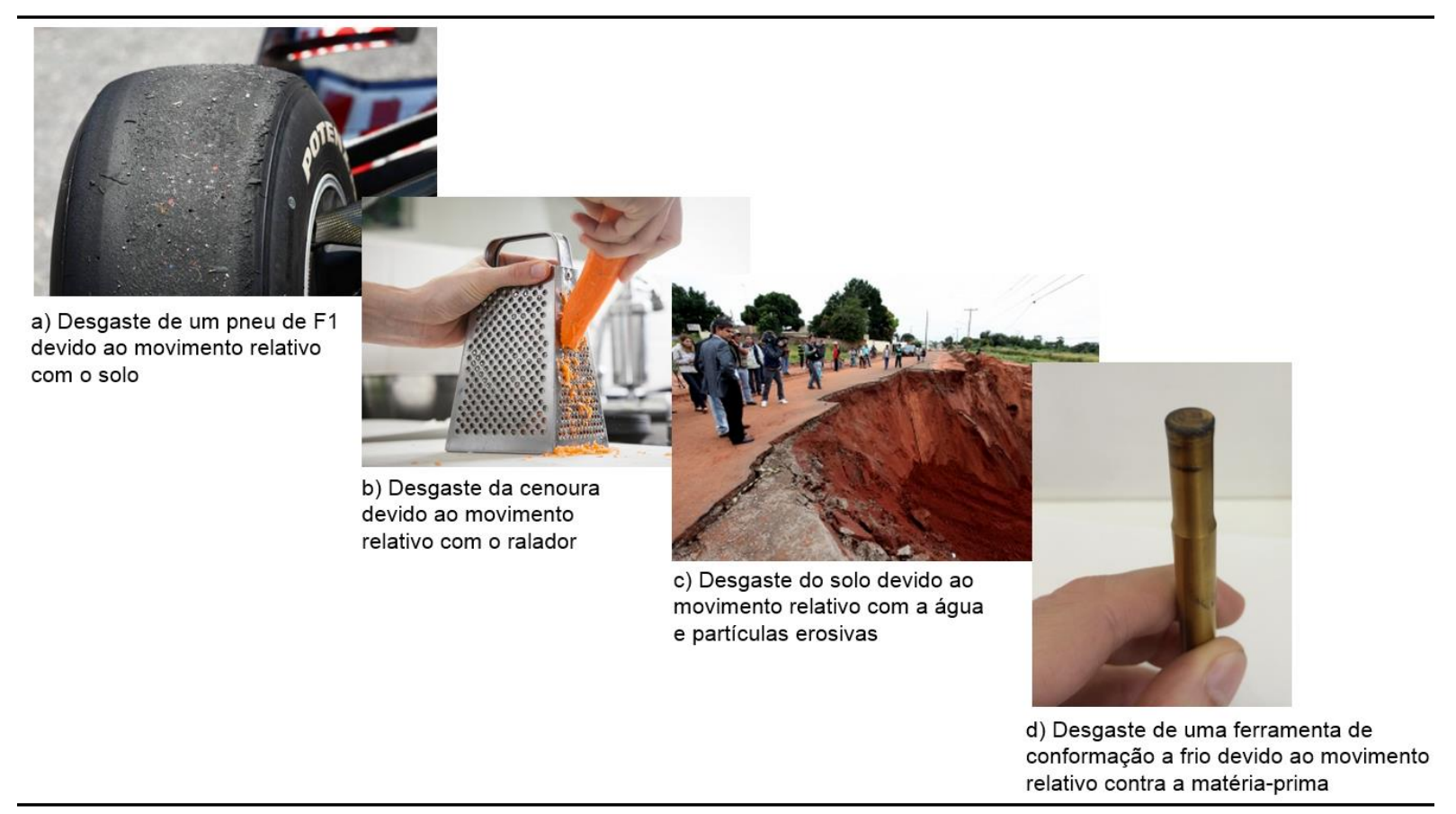


A Tribologia é a ciência dedicada ao estudo do desgaste e da interação entre corpos com movimento relativo. Além do desgaste, ela engloba as ciências do atrito, da lubrificação, e lida com os aspectos físicos, mecânicos, metalúrgicos e químicos do movimento relativo. A origem do termo "tribologia" vem da palavra grega $\tau \rho ı \beta o \sigma$ (tribos) que significa roçar ou esfregar, e foi enunciada pela primeira vez no Comitê do Departamento Britânico da Educação e Ciência em 1966. Neste ano, foi publicado um relatório que mostrou que 1\% do PIB de 1965 do Reino Unido poderia ter sido economizado se fosse dada maior atenção à tribologia (JOST, 1984). Após vinte e três anos, um novo relatório mostrou que $1 \%$ do PIB estava consideravelmente subestimado. Em 1990, já era amplamente aceito que uma atenção apropriada à tribologia, especialmente em educação, pesquisa e aplicação, poderia gerar uma economia de $1,3 \%$ a $1,6 \%$ do PIB de um país. Mais importante do que isso, é o fato de que $20 \%$ dessa economia pode ser obtida sem nenhum investimento significativo (JOST, 1984). Graças a esse cenário de potencial econômico, muitos países, estados, universidades e empresas vêm investindo maciçamente no seu estudo.

Toda análise de desgaste inicia-se com a definição do tribossistema. A Figura 20 apresenta um tribossistema genérico conforme norma DIN50320 (Adaptado de ZUM GAHR, 1987). A estrutura do sistema é determinada pelos elementos, suas propriedades e pela interação entre eles.

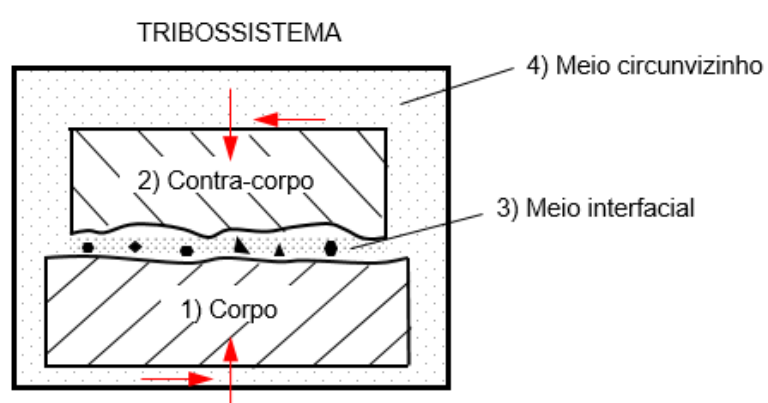

Figura 20 - Representação esquemática de um tribossistema e seus elementos (Adaptado de ZUM GAHR, 1987)

Os elementos do tribossistema são definidos da seguinte forma:

a) Corpo: Elemento do tribossistema que é o objeto de estudo.

b) Contra-corpo: Elemento com força e movimento relativo em relação ao corpo. 
c) Meio interfacial: Elemento presente entre o corpo e contra-corpo.

d) Meio circunvizinho: Ambiente que envolve o corpo e contra-corpo.

O desgaste pode ser dividido em diversos tipos, sendo que sua classificação varia de autor para autor. Zum Gahr (1987) classifica o processo em desgaste por deslizamento, desgaste por rolamento, desgaste por movimento oscilatório, desgaste por impacto e desgaste por erosão. Hutchings, por sua vez, se limita em classificar o processo em desgaste por deslizamento e desgaste por partículas duras. Segundo Hutchings (1992), "a nomenclatura do tipo e dos mecanismos de desgate varia entre os dois lados do atlântico" (HUTCHINGS, 1992). Por exemplo, o desgaste por deslizamento pode englobar o desgaste adesivo, o scuffing ${ }^{3}$, o galling ${ }^{3}$, scoring $^{3}$, enquanto o desgaste por partículas duras engloba 0 desgaste abrasivo, erosão, entre outros. Em casos que o contato entre os corpos geram níveis muito altos de tensão de forma repetida ao longo do deslizamento ou do rolamento, o termo "fadiga de contato" é utilizado.

Apresenta-se, a seguir, uma síntese dos tipos de desgaste mais relevantes para o presente trabalho, os quais se aplicam às ferramentas de conformação a frio.

\subsubsection{Abrasão}

O desgaste abrasivo ocorre quando o material é removido ou desplacado da superfície do corpo por partículas duras, ou então quando protuberâncias presentes no contra-corpo são forçadas e deslizadas ao longo da superfície do corpo (HUTCHINGS, 1992). Uma das classificações do desgaste abrasivo remete à forma como as particulas duras ou "debris" passam sobre a superfície. A literatura denota dois modos básicos de desgaste abrasivo (STACHOWIAK, 2009):

a) A dois corpos;

b) A três corpos.

A abrasão a dois corpos pode ser exemplificada pela ação de uma lixa sendo esfregada contra uma superfície, onde a partícula dura encontra-se aderida

\footnotetext{
${ }^{3}$ Scuffing e scoring podem ser traduzidos como "engripamento", enquanto galling é uma forma mais severa de scuffing e é utilizada frequentemente para caracterizar adesão em ferramentas de conformação.
} 
ao contra-corpo. As partículas duras passam pela superfície como uma ferramenta de corte. Na abrasão a três corpos os debris estão livres para deslizar ou girar ao longo da superfície. A abrasão a dois e a três corpos está ilustrada esquematicamente na Figura 21.

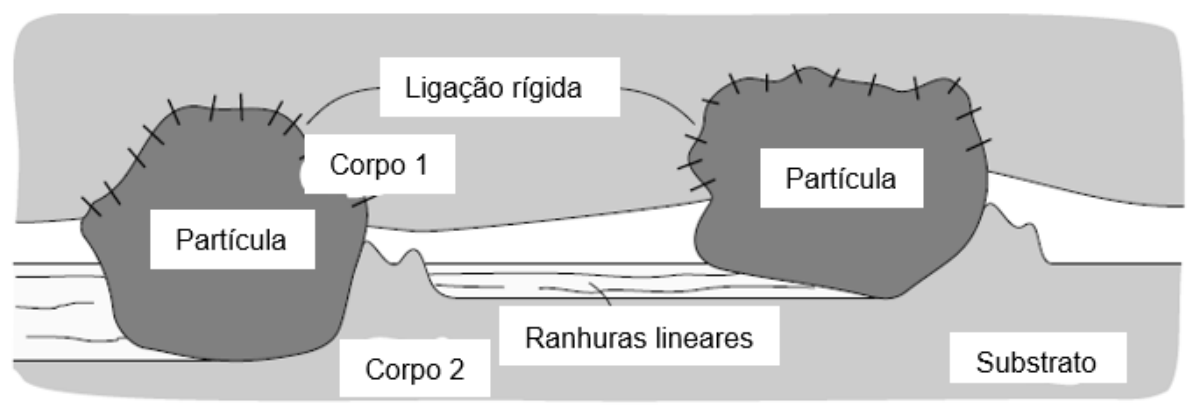

A dois corpos
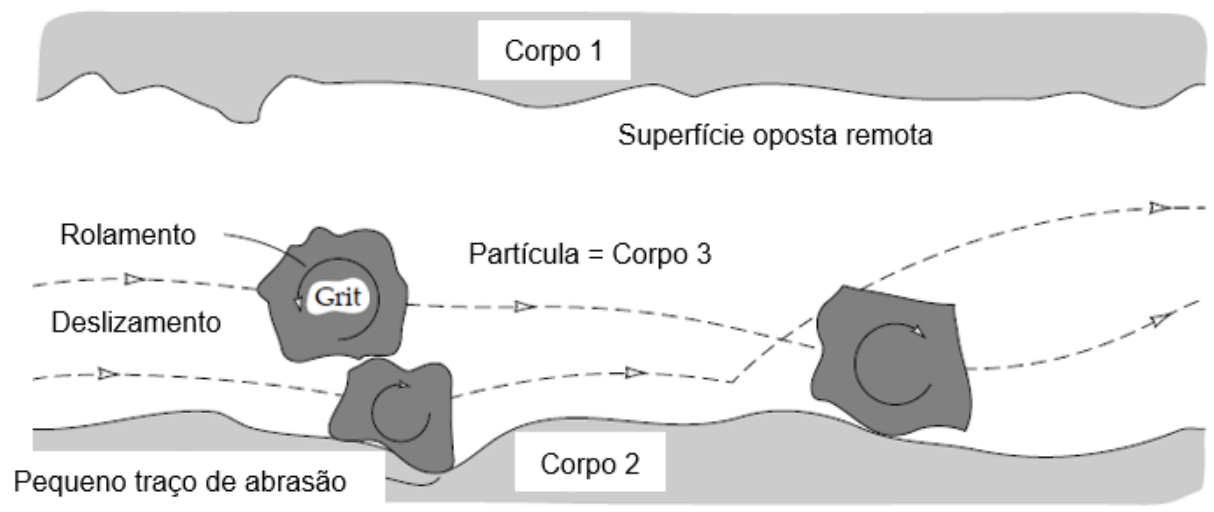

A três corpos

Figura 21 - Abrasão a dois e a três corpos (STACHOWIAK, 1993)

Autores como Gates (1998) e Trezona et al. (1999) discutiram o uso desta classificação e esclareceram que a cinemática da partícula é que determina a classificação, sendo que o desgaste abrasivo ocorre por deslizamento quando o abrasivo risca continuamente o corpo, ou por rolamento quando a cinemática da partícula abrasiva é essencialmente rolamento. Essa classificação baseada nos mecanismos envolvidos na abrasão é a abordagem mais moderna e utilizada nos fóruns de tribologia atualmente (GATES, 1998 e TREZONA, 1999).

A dureza das partículas duras envolvidas na abrasão influencia diretamente a taxa de desgaste, sendo que em geral partículas com uma dureza menor causarão menos desgaste se comparadas com partículas de maior dureza. Hutchings relatou que ensaios empíricos realizados com partículas de diversas formas mostraram que ocorrerá desgaste abrasivo se a razão entre a dureza do abrasivo $\mathrm{H}_{\mathrm{a}}$ e a dureza da 
superfície $H_{s}$ for maior que 1,2. Para relações de dureza $H_{a} / H_{s}$ inferiores a 1,2 é possível ocorrer deformação plástica da partícula conforme ilustrado na Figura 22. Abrasão em condições onde $\mathrm{H}_{\mathrm{a}} / \mathrm{H}_{\mathrm{s}}$ é menor que 1,2 é eventualmente intitulada abrasão moderada, em contraste à abrasão severa onde $\mathrm{H}_{\mathrm{a}} / \mathrm{H}_{\mathrm{s}}$ é maior que 1,2.

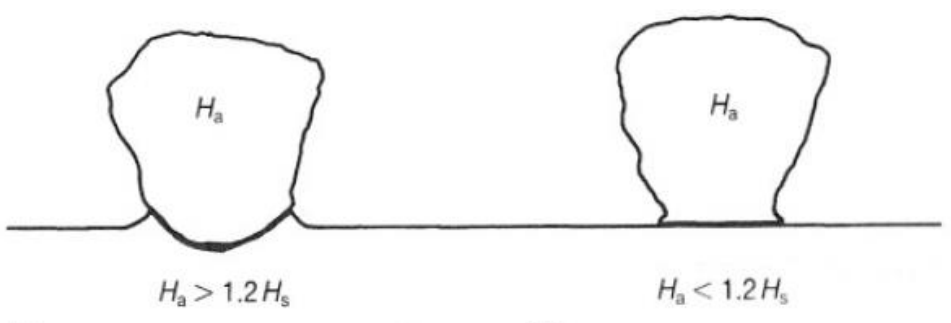

(a)

(b)

Figura 22 - llustração do contato entre uma partícula dura sob carga normal em uma superfície plana. (a) quando $\mathrm{Ha} / \mathrm{Hs}$ é maior que $1,2 \mathrm{e}(\mathrm{b})$ quando $\mathrm{Ha} / \mathrm{Hs}$ é menor que 1,2

(HUTCHINGS, 1992)

Em um sistema onde há interação de superfícies com durezas distintas, como no processo de conformação a frio, as partículas duras são pressionadas entre a ferramenta e a matéria-prima, sendo que estas podem ou não se tornar solidárias à superfície mais mole. Durante o movimento relativo inerente ao processo de conformação, as partículas duras removem material das ferramentas por microcorte, conforme exemplificado na Figura 23.

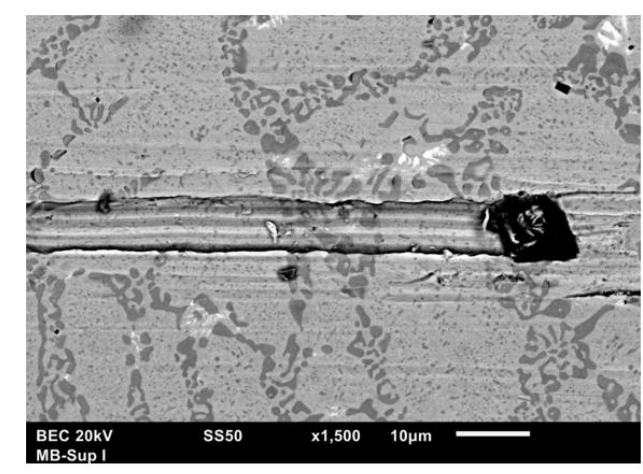

(a)

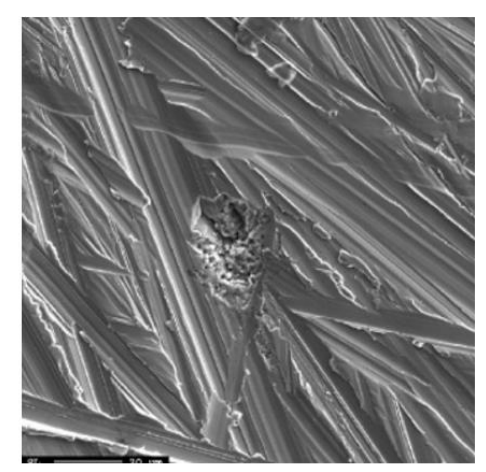

(b)

Figura 23 - Aspectos de superfícies danificadas por abrasão obtidas por MEV. a) Exemplo de microcorte causado por uma única partícula dura e b) cortes causados por múltiplas partículas (Cortesia de Jimmy Penagos - Laboratório de Fenômenos de Superfície da USP)

Originalmente, o desgaste abrasivo foi pensado como sendo apenas cortes na superfície causados por partículas duras. No entanto, análises microscópicas revelaram que outros mecanismos estão envolvidos no processo. As partículas duras podem remover material da superfície por microcorte, microsulcamento, microfratura, despaclamento ou fadiga por repetidas deformações plásticas, conforme ilustrado na Figura 24 (STACHOWIAK, 1993). 


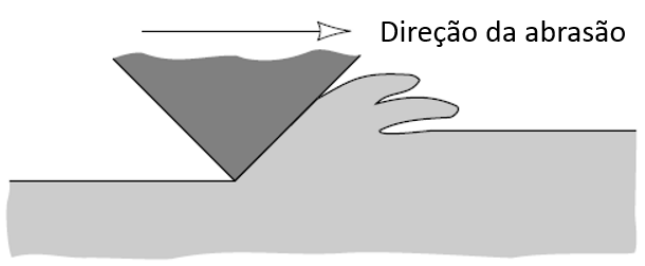

a) Corte

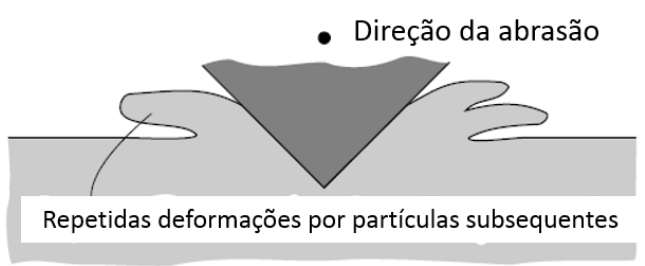

c) Fadiga devido à sucessíveis sulcamentos

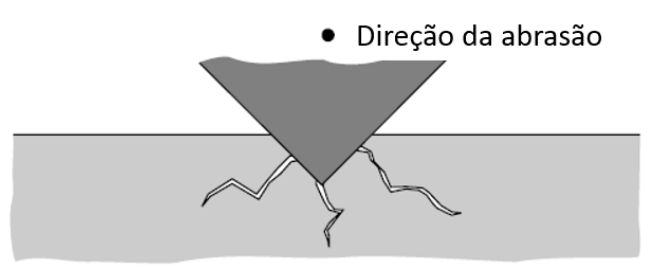

b) Fratura

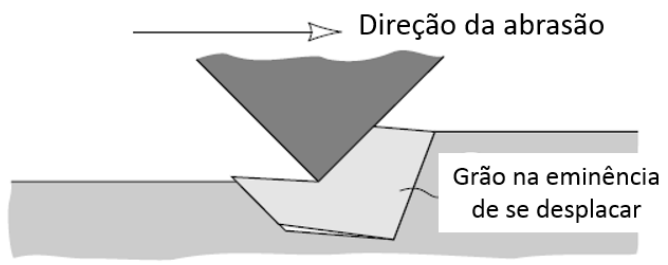

d) Desplacamento

Figura 24 - Mecanismos do desgaste abrasivo: (a) Microcorte, (b) fratura, (c) fadiga por excessivo microsulcamento e (d) desplacamento (STACHOWIAK, 1993)

Os mecanismos envolvidos no desgaste de ferramentas de conformação depende das particularidades do tribossistema em que estão envolvidas. Falconnet (2015) analisou o perfil de desgaste de um punção de conformação a frio utilizado para moldar chapas de cobre. Após observar as imagens do punção novo e usado em microscópio eletrônico de varredura (MEV), o autor concluiu que o desgaste do punção foi ocasionado puramente por microcorte (Figura 25).

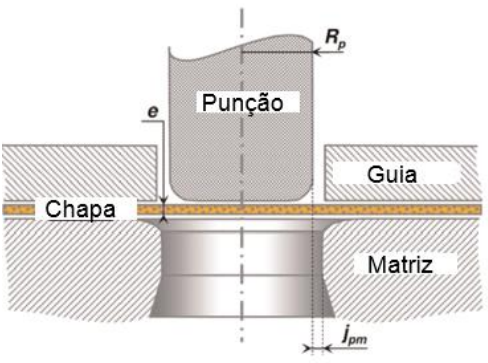

(a)
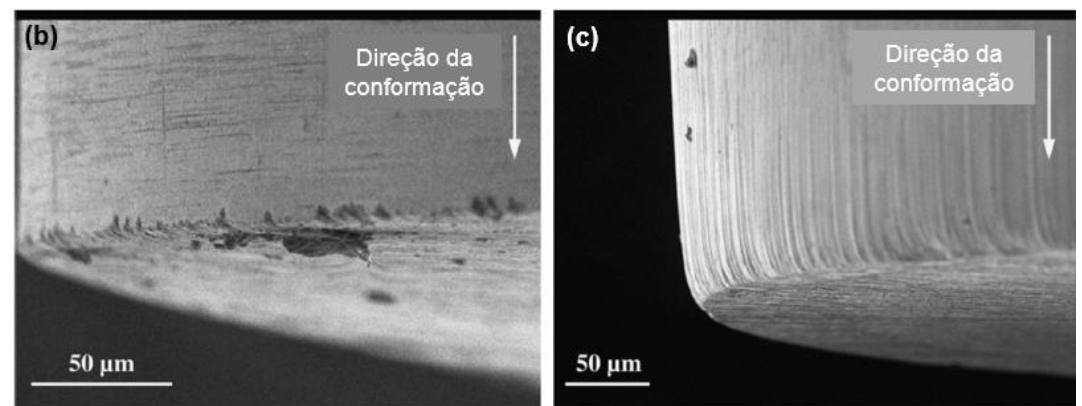

Figura 25 - Tribossistema analisado e imagens obtidas por microscópio eletrônico de varredura (MEV): a) Tribossistema; b) Punção novo com 500 vezes de aumento; b) Punção usado com 300 vezes de aumento (Adaptado de FALCONNET, 2015)

Diversos modelos analíticos foram desenvolvidos para quantificar 0 desgaste abrasivo. Um dos modelos mais simples e mais antigos considera uma partícula abrasiva na forma de cone indentando e deslizando em uma superície, conforme ilustrado na Figura 26. Neste modelo, assume-se que todo material removido pelo cone é perdido como um debri do desgaste. 


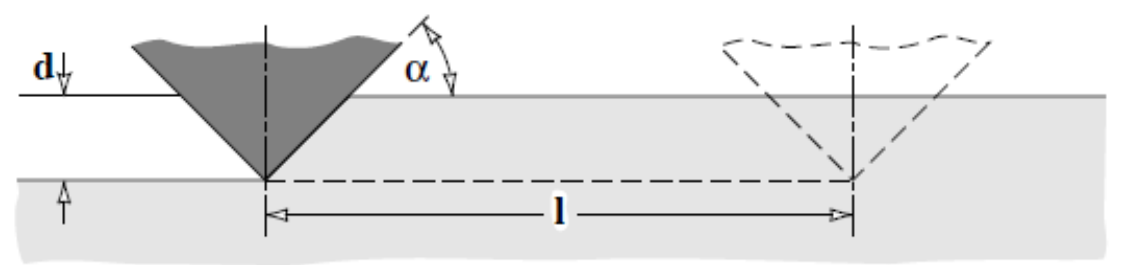

Figura 26 - Modelo de desgaste abrasivo causado por uma única partícula (STACHOWIAK, 1993)

A quantidade de material removido por unidade de distância $(\mathrm{Q})$ é dada por:

$$
Q=\frac{K \cdot W}{H}
$$

onde W é a carga normal aplicada, $\mathrm{H}$ é a dureza do corpo mais mole e $\mathrm{K}$ é uma constante que indica a severidade do desgaste. A Equação 1 é a mesma que Archard propôs para quantificar a perda de material no desgaste por deslizamento, mesmo o autor partindo de considerações iniciais diferentes. $\mathrm{O}$ valor de $\mathrm{K}$ varia em função do tipo e das condições de cada tribossitema. Para desgaste abrasivo a dois corpos $\mathrm{K}$ geralmente varia entre $5 \times 10^{-3}$ e $50 \times 10^{-3}$, enquanto que para desgaste abrasivo a três corpos $\mathrm{K}$ geralmente varia entre $0,5 \times 10^{-3}$ e $5 \times 10^{-3}$ (HUTCHINGS, 1992).

Independente do valor de $\mathrm{K}$, a equação 1 mostra que o desgaste é proporcional à carga normal aplicada e inversamente proporcional à dureza do corpo mais mole. Ou seja, assumindo que existam partículas duras no meio interfacial durante o processo de conformação a frio, o desgaste das ferramentas pode ser minimizado com o aumento da dureza. As partículas duras, responsáveis pelo desgaste das ferramentas, podem ser geradas por elementos presentes no sistema, excessivamente encruados devido aos sucessívos ciclos de conformação, ou então por partículas metálicas liberadas após o desgaste iniciado por adesão.

\subsubsection{Adesão}

Adesão é o fenômeno resultante de forças atrativas entre duas superfícies em contato. Esse fenômeno é governado por ligações iônicas, covalentes, metálicas ou ligações de van der Waals, sendo que a intensidade dessas ligações depende da 
afinidade química entre os corpos em contato (ZUM GAHR, 1987). Quando duas superfícies se tocam, o contato se dá inicialmente entre as asperezas. Com o aumento da carga normal e subsequente movimento relativo, as áreas reais de contato entre as superfícies formam as junções adesivas. O tamanho dessas junções aumenta a medida que uma força tangencial é introduzida no sistema, o que altera 0 estado de tensões de uniaxial compressivo para biaxial com compressão e tração. Eventualmente, ocorre o cisalhamento das junções no material mais fraco, o que leva à uma transferência de material de uma superfície para a outra. O material removido pode se despreender após sucessívos contatos e gerar uma partícula dura para o desgaste abrasivo. O processo de transferência de material gerado por adesão está ilustrado esquematicamente na Figura 27. Nas condições onde há formação de saliências em um dos corpos e surgimento de vales no outro, o termo galling é comumente usado para descrever que houve desgaste severo iniciado por adesão (WILSON,1997).

a) Aproximação

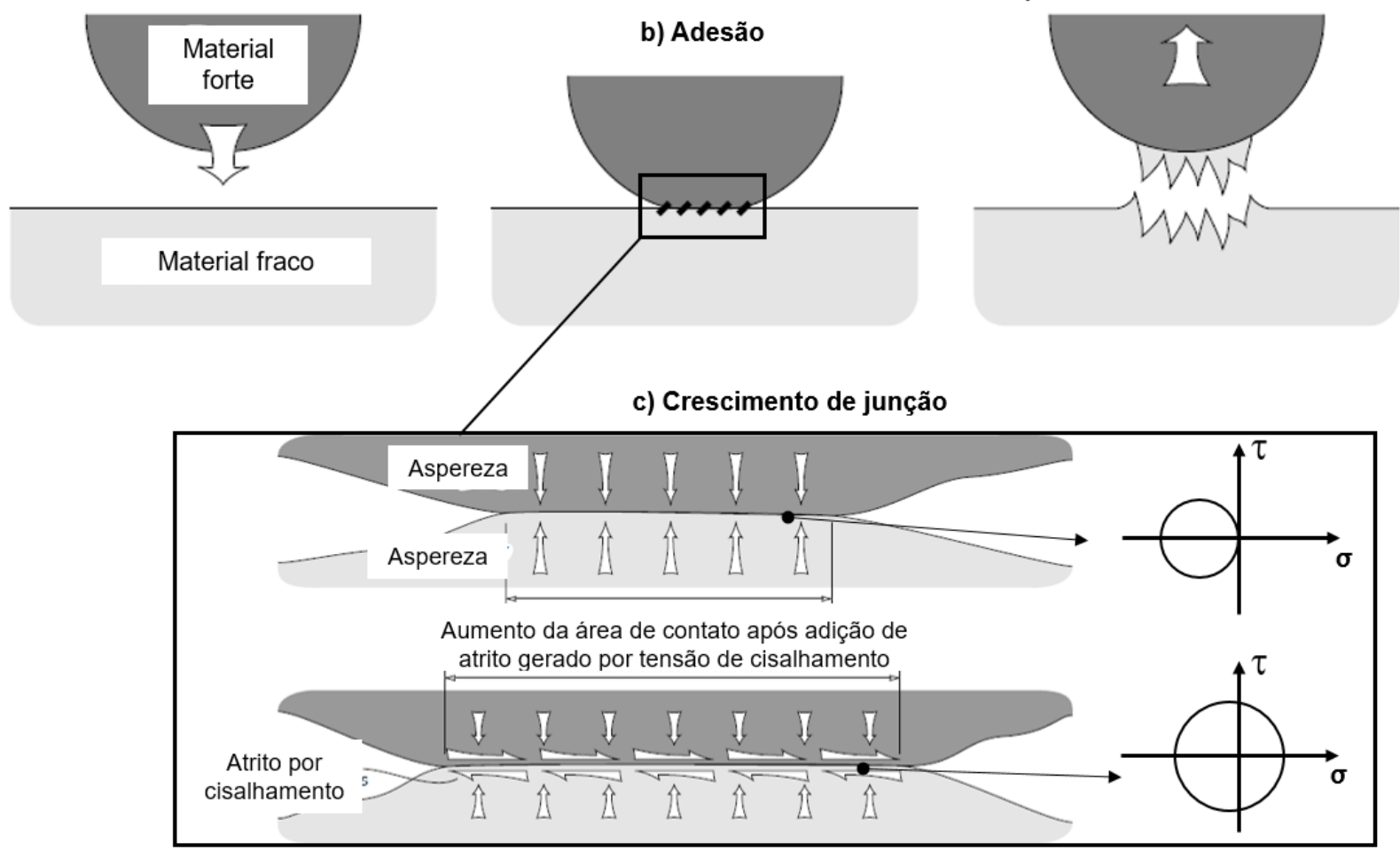

Figura 27 - Sequência de eventos no desgaste gerado por adesão (Adaptado de STACHOWIAK, 1993)

Os trabalhos de Bowden e Tabor oferecem evidências suficientes da influência do atrito na adesão. O termo adesão foi associado à força necessária para cisalhar as junções criadas durante o contato entre os corpos e promover a 
transferência de material entre as superfícies. A força de adesão $F_{a}$ foi calculada como o produto entre a área real de contato $A_{r}$ e a resistência ao cisalhamento do material Ta, conforme mostrado na equação 2 (BOWDEN; TABOR, 1950).

$$
F_{a}=A_{r} \tau_{a}
$$

Sabendo que a força de adesão também pode ser calculada como o produto entre a força normal $F_{n}$ e o coeficiente de atrito devido à adesão $\mu_{a}$, a seguinte relação é estabelecida:

$$
\mu_{a}=\frac{F_{a}}{F_{n}}=\frac{A_{r} \tau_{a}}{F_{n}}=\frac{\tau_{a}}{p_{r}}
$$

onde $p_{r}$ corresponde à tensão real média.

Bowden e Tabor assumiram que as asperezas se deformam até o material mais mole escoar, atingindo-se uma pressão de contato igual à dureza do material mais mole. Dessa forma, a relação entre área real de contato $A_{r}$ e dureza do corpo mais mole $H_{m}$ é dada por:

$$
A_{r}=\frac{F_{n}}{H_{m}}
$$

Portanto, é possível relacionar o coeficiente de atrito por adesão com a dureza do material mais mole da seguinte forma:

$$
\mu_{a}=\frac{F_{a}}{F_{n}}=\frac{A_{r} \tau_{a}}{A_{r} H_{m}}=\frac{\tau_{a}}{H_{m}}
$$

A equação 5 revela que uma forma de diminuir o coeficiente de atrito e, consequentemente, a força de adesão, consiste em reduzir a área real de contato, sendo que isso pode ser feito a partir do aumento da dureza do material mais mole. Assim, como apresentado na seção 3.4.1, o aumento da dureza das ferramentas de conformação a frio pode contriubir não apenas para reduzir o desgaste abrasivo, como também tende a minimizar a transferência de material originada por adesão. A Figura 28 exemplifica a transferência de material ocasionada por adesão que pode ocorrer durante o processo de conformação. 

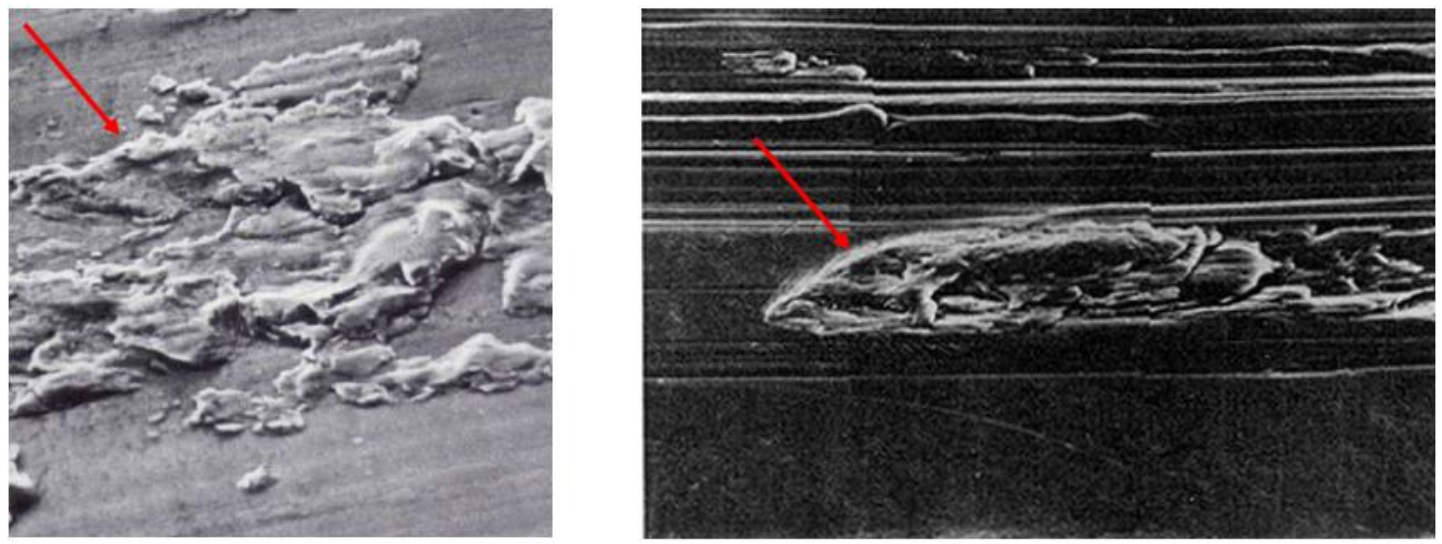

Figura 28 - Exemplo de trasferência de partículas metálicas causada por adesão (KOMVOPOULOS, 1985)

As partículas abrasivas responsáveis pelo desgaste das ferramentas de conformação a frio, podem ter sua origem relacionada com a transferência de material causada por adesão, uma vez que o material removido pode se despreender após sucessívos ciclos de conformação e gerar uma partícula altamente encruada, o que resultaria em riscos e cortes na superfície (SHEU, 1998). A partícula encruada pode aderir-se à um dos corpos em contato e promover o sulcamento do substrado mais mole. Apesar do sulcamento ser um mecanismo de desgaste menos severo do que o microcorte, ele pode levar à nucleação de trincas na superfície desgastada devido à altas tensões trativas geradas pelo atrito entre a partícula transferida e o substrato mais mole (STACHOWIAK, 1993). O mecanismo de sulcamento por partículas transferidas está ilustrado na Figura 29. Nota-se que o sentido de formação das trincas é perpendicular ao deslizamento entre os corpos.

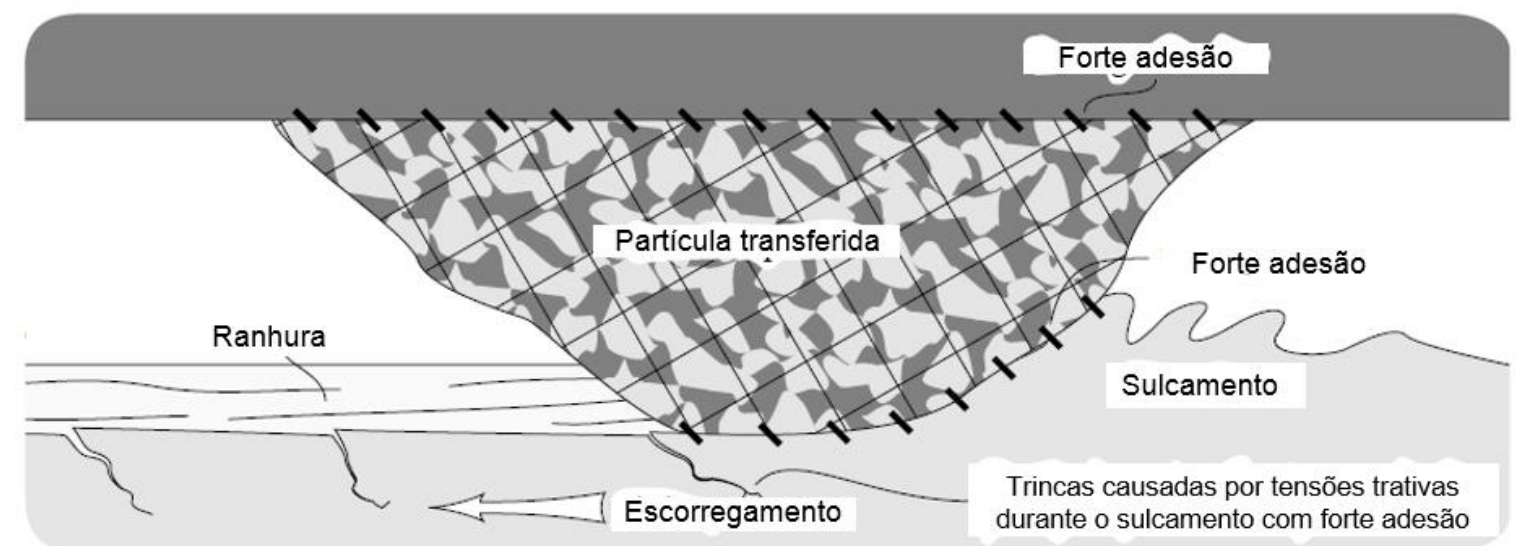

Figura 29 - Mecanismo de formação de sulcos em superfícies desgastadas pelo encruamento de partículas transferidas (STACHOWIAK, 1993)

Logo, busca-se sempre evitar que o fenômeno de adesão ocorra, seja por meio de lubrificação, ou alteração do acabamento superficial. 


\subsubsection{Fadiga superficial}

O desgaste devido à fadiga superficial é caracterizado por formação de trincas e desplacamento de material causado por repetidos carregamentos cíclicos em superfícies sólidas em contato. O contato por rolamento ou escorregamento de sólidos, ou o impacto de sólidos em contato, com ou sem a presença de lubrificantes, resulta em tensões cíclicas na superfície, o que pode levar à fadiga localizada em escala microscópica (ZUM GAHR, 1987).

Análises das seções transversais das superfícies desgastadas geralmente revelam intensa deformação plástica do material imediatamente abaixo da superfície (STACHOWIAK, 1993). Stachowiak (1993) mostrou que em condições severas de deslizamento com elevados coeficientes de atrito, uma espessura de material de aproximadamente $0,1 \mathrm{~mm}$ deformou-se na direção do escorregamento devido à força de atrito. Em condições com baixo coeficiente de atrito, as quais prevalecem em sistemas lubrificados, a deformação da superfície é consideravelmente menor ou até mesmo ausente.

As deformações causadas por cisalhamento durante o escorregamento estão presentes não apenas na superfície, mas também abaixo dela. A Figura 30 mostra os níveis de deformação de superfícies que sofreram desgaste por fadiga. Os níveis de deformação plástica dependem da ductilidade do material e das condições impostas durante o deslizamento.

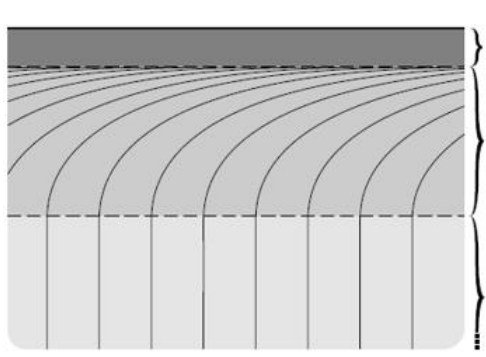

Figura 30 - Níve
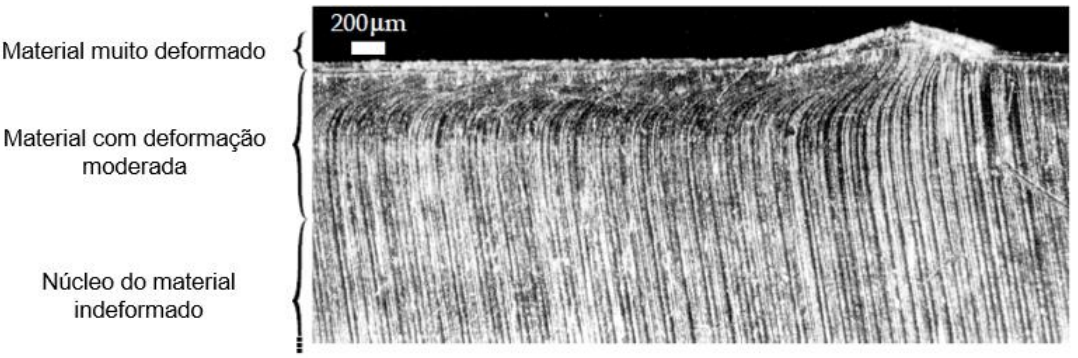

(Adaptado de STACHOWIAK, 1993)

Com o progresso da deformação plástica, as discordâncias se acumulam e geram regiões de alta energia (DIETER, 1988). Essas regiões de alta energia são potenciais áreas de nucleação e propagação de trinca. A formação de partículas de desgaste pode ser iniciada nessas áreas, as quais são orientadas perpendicularmente à direção do deslizamento. Dependendo da geometria dos 
corpos em contato e da ductilidade dos materiais envolvidos, as trincas podem nuclear abaixo da superfície e posteriormente propagar até a superfície, resultando em um desplacamento de uma partícula de desgaste (STACHOWIAK, 1993). O mecanismo de formação de partículas de desgaste devido à propagação de trincas iniciadas na superfície está ilustrado na Figura 31.
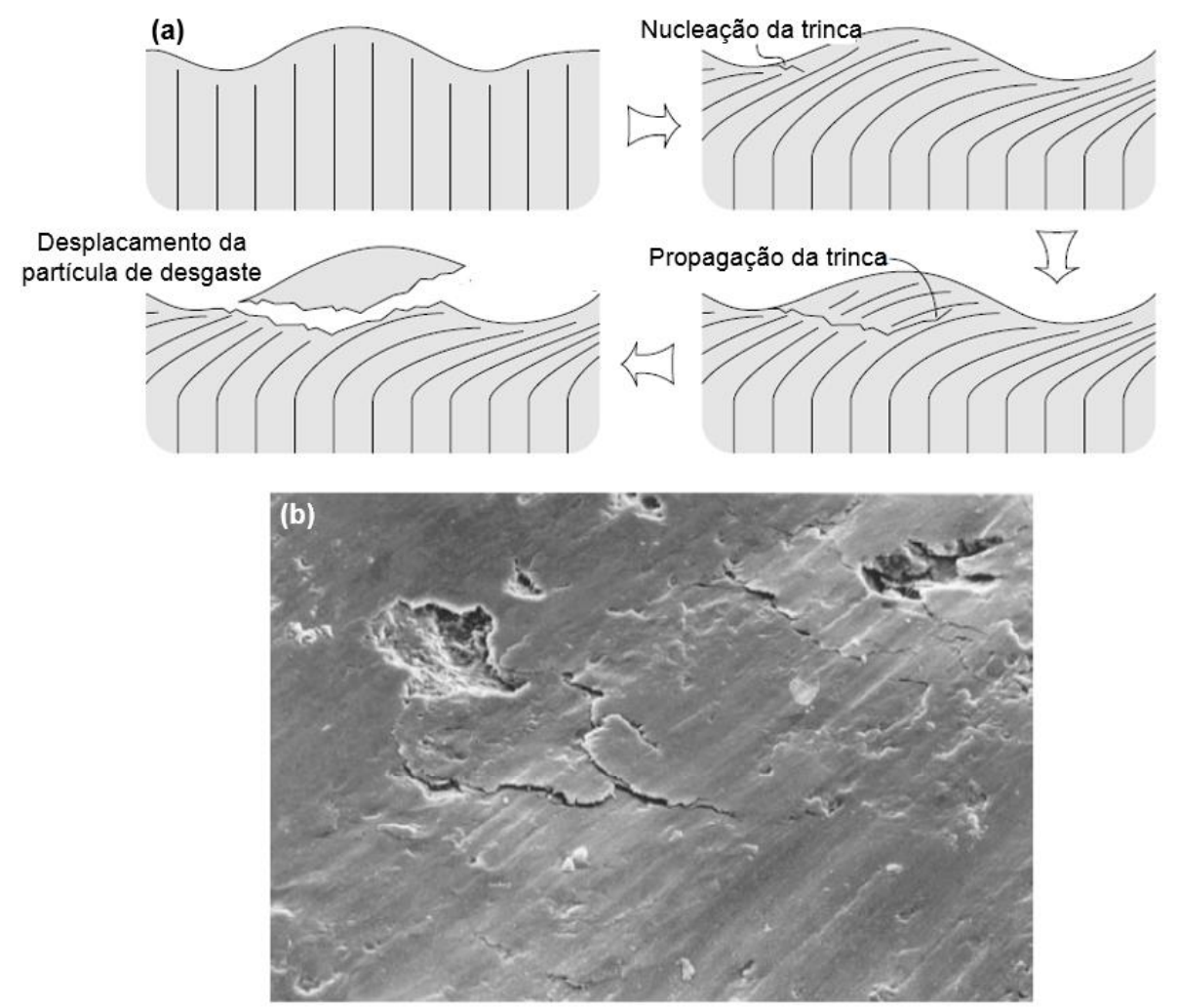

$100 \mu \mathrm{m}$

Figura 31 - (a) Ilustração do mecanismo de formação de partículas devido ao crescimento de trincas iniciadas na superfície; (b) Exemplo de formação de partícula gerada por desgaste por fadiga (STACHOWIAK, 1993)

A Figura 32 mostra a superfície de um punção de conformação a frio, utilizado para cortar chapas de aço inoxidável, a qual apresenta um padrão de trincas perpendiculares ao deslizamento de material, ou seja, as trincas são causadas primariamente por força de atrito. Inicialmente, nenhuma perda de material foi associada às trincas, de forma que o desempenho da ferramenta não foi alterado. No entanto, o desgaste começou a acelerar após certo número de ciclos, a ponto de deteriorar as tolerâncias do produto cortado. Finalmente, uma das trincas transversais ao movimento iniciou uma fratura em larga escala no raio do punção, o que determinou o fim da vida útil da ferramenta (ASM HANDBOOK, 1992). A mesma descrição fenomenológica que explica a formação de trincas perpendiculares ao 
sentido de deslizamento é dada por Stachowiak na Figura 29, a qual relaciona a nucleação de trincas com tensões trativas geradas por atrito (STACHOWIAK, 1993).

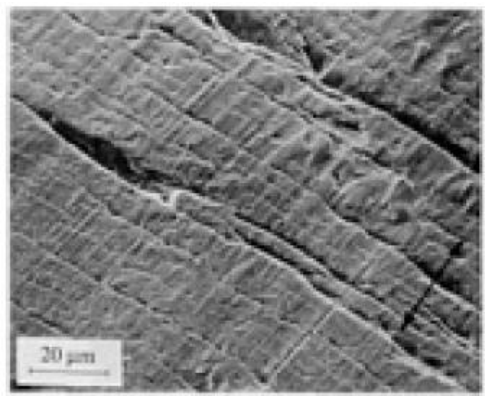

Figura 32 - Imagem em MEV mostrando fratura por fadiga em um punção de aço AISI D1 utilizado para cortar chapas de aço inoxidável (ASM HANDBOOK, 1992)

\subsection{Relação entre rugosidade e desgaste}

Relacionar o efeito da rugosidade com o desgaste de dois corpos em contato por deslizamento representa um grande desafio para os pesquisadores. As principais dificuldades devem-se ao fato que o acabamento superficial inicial é alterado durante o período de running-in, e as particularidades de cada tribossistema podem resultar em desgastes distintos para corpos com a mesma topografia inicial. Zum Gahr (1987) exemplifica, para um caso de deslizamento a seco entre corpos planos ou cilíndricos de bronze ou ferro fundido, que o desgaste reduz quatro vezes quando a rugosidade média reduz de $11 \mu \mathrm{m}$ para $2 \mu \mathrm{m}$. Em contrapartida, para um caso de deslizamento a seco entre corpos de aço, nenhuma influência no desgaste foi observada para rugosidades variando entre 0,1 $\mu \mathrm{m}$ e 1,8 $\mu \mathrm{m}$ (ZUM GAHR, 1987). O resultado do primeiro estudo pode ser explicado com a mudança do mecanismo de desgaste passando de microcorte para microsulcamento, enquanto o segundo estudo indica que para rugosidades muito baixas o desgaste é praticamente por deslizamento com uma ligeira tendência à adesão. Logo, o efeito da rugosidade no desgaste pode variar em função do tribossistema.

A Figura 33 apresenta uma possível relação entre rugosidade e intensidade de desgaste proposta por Zum Gahr (1987) para corpos metálicos submetidos ao deslizamento. No contado não lubrificado, o desgaste devido à abrasão é reduzido à medida que a rugosidade diminui. A intensidade do desgaste dos pares em contato aumenta devido à adesão quando a rugosidade fica abaixo de um valor crítico. No contato com filmes lubrificantes finos, superfícies lisas com uma espessura 
específica de filme $\lambda$ maior que 1 são separadas evitando a adesão. A espessura de filme específica é definida como a relação entre a espessura do filme elastohidrodinâmico e a rugosidade rms da superfície. Para $\lambda$ menor que 1 , devido ao aumento da rugosidade a uma dada espessura de filme, o contato entre asperezas das superfícies em contato é aumentado. Aumentando a espessura do filme lubrificante o contato entre asperezas é evitado. Zum Gahr (1987) ainda demonstra analiticamente que o coeficiente de atrito e o coeficiente de desgaste aumentam durante o contato de superfícies lisas se a adesão é dominante. Além disso, os modelos teóricos mostram que o coeficiente de desgaste aumenta se a superfície do corpo se torna mais lisa e mais mole devido à ação mecânica ou térmica durante o deslizamento (ZUM GAHR, 1987).

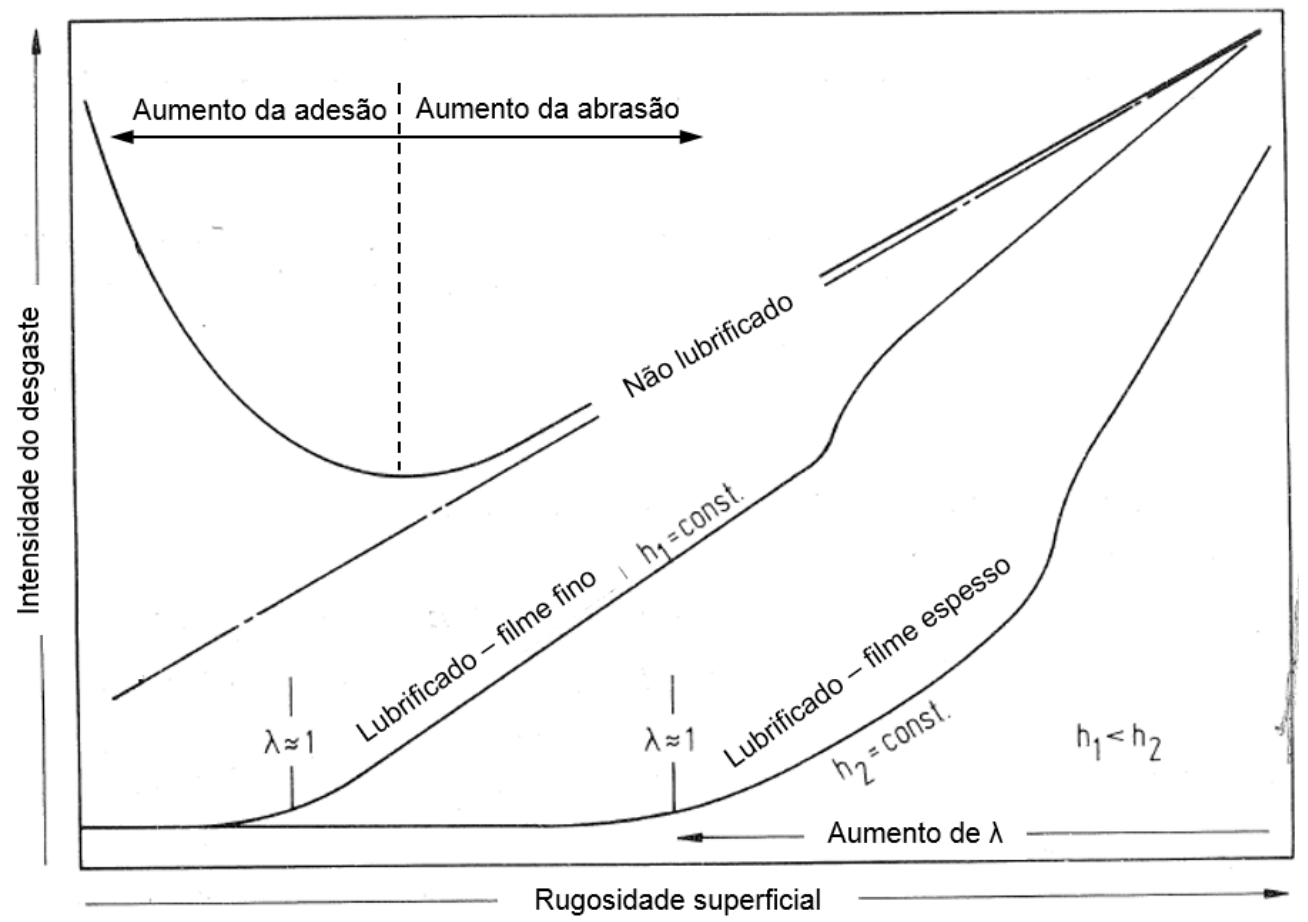

Figura 33 - Intensidade do desgaste em função da rugosidade em contatos lubrificados e não lubrificados. " $h$ "é a espessura do filme elastohidrodinâmico e $\lambda$ é a espessura de filme específica (Adaptado de ZUM GAHR, 1987)

Sedlacek, Podgornik e Vizintin (SEDLACEK, 2009) conduziram um estudo sobre a influência da preparação superficial na rugosidade, no atrito e no desgaste. Os autores fabricaram diversos discos de aço $100 \mathrm{Cr} 6 \mathrm{com}$ rugosidades médias diferentes, utilizando processos de retífica, polimento, torneamento e fresamento. As diferentes técnicas de preparação resultaram em valores de $R_{a}$ entre $0,02 \mu \mathrm{m}$ e $7 \mu \mathrm{m}$. Após a preparação das amostras, foram conduzidos ensaios de pino-disco 
com diferentes condições de contato, sendo que uma esfera de $\mathrm{Al}_{2} \mathrm{O}_{3}$ foi usada como contra-corpo.

Apesar das tentativas, os autores não conseguiram correlacionar de forma direta a rugosidade com o desgaste, pois as superfícies iniciais foram severamente danificadas pelo contato em um espaço de tempo muito curto. Dessa forma, os autores limitaram-se a relacionar a rugosidade com o coeficiente de atrito da seguinte forma:

a) No ensaio a seco, as amostras retificadas mais rugosas apresentaram os menores coeficientes de atrito para todas as velocidades de deslizamento. As amostras torneadas apresentaram coeficientes de atrito menores para as rugosidades menores.

b) No ensaio lubrificado, as superfícies retificadas mais lisas apresentaram menor coeficiente de atrito, provavelmente porque o regime de lubrificação se manteve no elastohidrodinâmico. As amostras torneadas com a superfície mais lisa apresentaram coeficiente de atrito similar às amostras torneadas com a superfície mais rugosa.

O principal entendimento do trabalho de Sedlacek (2009) é que superfícies fabricadas com processos de fabricação distintos apresentam comportamentos tribológicos totalmente diferentes, ainda que as superfícies apresentem valores de rugosidade similares.

Schey (1984) correlacionou o efeito da rugosidade no desgaste de matrizes com o coeficiente de atrito por meio de ensaios de compressão de anel, utilizando lubrificantes de baixa e de alta viscosidade (Figura 34), sendo que a força de atrito, a qual é proporcional ao coeficiente de atrito, é prejudicial à durabilidade das ferramentas. 


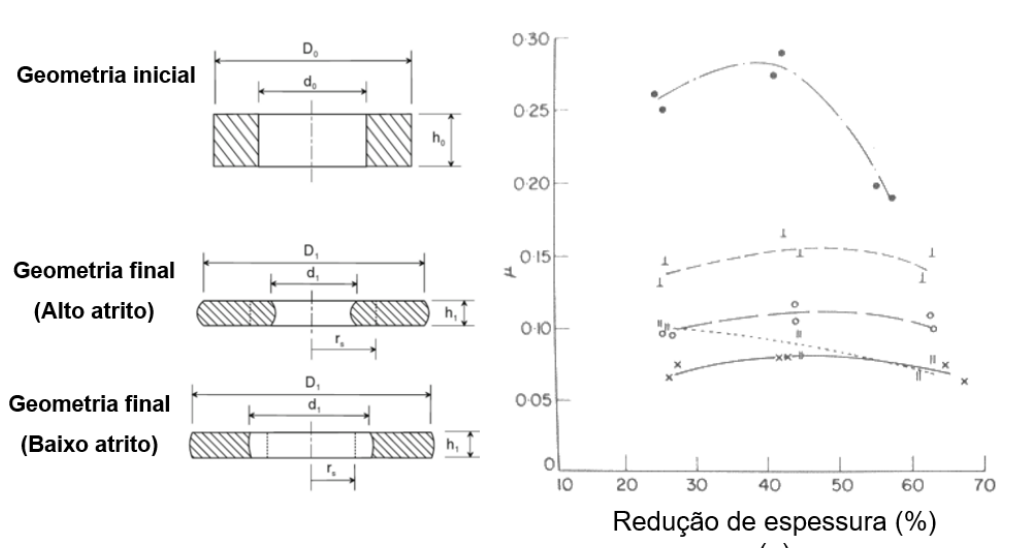

(a)

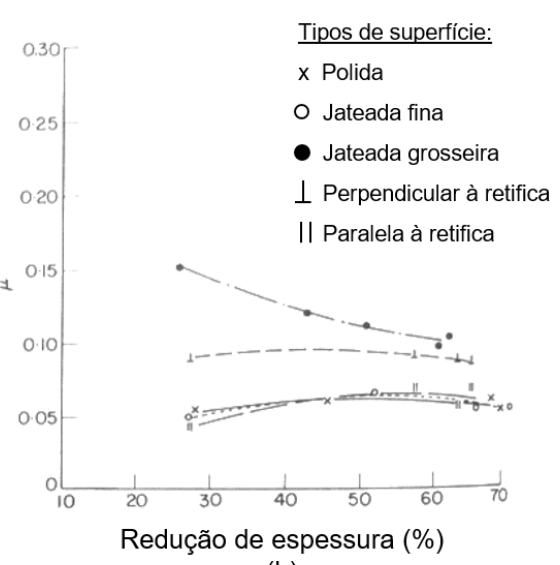

(b)

Figura 34 - Efeito da rugosidade das matrizes no atrito em ensaios de compressão de anel com óleo de baixa (a) e de alta (b) viscosidade (Adaptado de SCHEY, 1984)

Schey concluiu que, com o lubrificante de baixa viscosidade, as matrizes mais rugosas apresentam maior coeficiente de atrito, uma vez que asperezas maiores atravessam o filme lubrificante e penetram no contra-corpo. Com o lubrificante de alta viscosidade, o atrito é em geral menor e, com exceção da matriz jateada com acabamento grosseiro e da matriz retificada com orientação perpendicular ao deslizamento, todos os outros acabamentos superficiais resultaram em atritos praticamente idênticos, uma vez que o lubrificante é espesso suficiente para mascarar seus efeitos.

Ainda segundo Schey (1984), em regimes de lubrificação limítrofe, as asperezas das matrizes endurecidas são, em geral, prejudiciais uma vez que elas atravessam o filme lubrificante e, se houver afinidade química entre os materiais da ferramenta e da contra-peça, a adesão pode ocorrer. Logo, a rugosidade das matrizes é geralmente indesejada e cuidados devem ser tomados no acabamento superficial das ferramentas para que as marcas de polimento estejam na direção de deslizamento de material.

Podgornik e Leskovsek apresentaram diversas técnicas para "engenheirar" superfícies de ferramentas de conformação a frio com o objetivo de aumentar a resistência ao desgaste (PODGORNIK, 2015). Uma das técnicas remete a trabalhos publicados em 2004 e 2012 por Podgornik, Hogmark, Sandberg e Jerina, os quais investigaram a influência da rugosidade na resistência ao galling de ferramentas de conformação por meio de um método de teste específico para esse objetivo (PODGORNIK, 2012). Os autores descartaram o método pino contra disco pois durante o processo de conformação, tanto para chapas como para blanks, uma 
matéria-prima "nova" entra em contato com a ferramenta a cada ciclo de produção. A Figura 35 apresenta esquematicamente o método utilizado pelos autores para investigar o efeito da rugosidade na resistência ao galling das ferramentas. Apesar de não corresponder diretamente a uma operação de conformação, a configuração cruzada dos cilindros permite um aumento gradual de carga durante um único ciclo, sendo que cada ponto ao longo da superfície de contato de ambos os cilindros corresponde a uma carga específica e a um único histórico de contato.

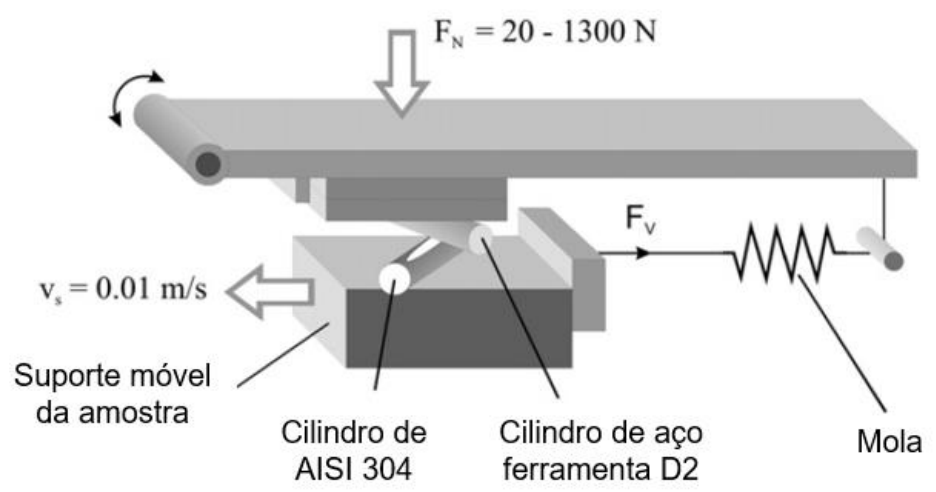

Figura 35 - Aparato experimental conhecido como "load scanning test rig" (PODGORNIK, 2012)

Os autores construíram corpos de prova cilíndricos de aço ferramenta AISI D2, endurecidos a $900 \mathrm{HV}$ com diferentes níveis de rugosidade e divididos em cinco grupos conforme mostrado na Tabela 5. Construíram também contra-corpos cilíndricos de aço inoxidável AISI 304 endurecidos a 355 HV com rugosidade $R_{a}$ de aproximadamente $0,2 \mu \mathrm{m}$, os quais foram forçados a deslizar contra o cilindro estacionário de aço ferramenta de interesse com velocidade constante de $0,01 \mathrm{~m} / \mathrm{s}$ e cargas variando entre $20 \mathrm{~N}$ e $1300 \mathrm{~N}$.

A Figura 36 sintetiza os resultados obtidos por Podgornik (2012) sobre 0 efeito da rugosidade e da topografia na carga crítica para formação de camada transferida (galling), do cilindro de aço inoxidável para o cilindro de aço D2, em contato lubrificado. Fica evidente que, para o tribossistema analisado, quanto menor a rugosidade maior é a carga crítica para que o galling se inicie, tanto para os cilindros sem revestimento como para os revestidos. Essa é a principal conclusão dos autores, sendo que com base nos resultados dos ensaios, eles recomendam fortemente para que as superfícies das ferramentas sejam polidas a fim de aumentar a resistência ao desgaste. No entanto, vale lembrar que os resultados obtidos por meio do ensaio apresentado na Figura 35 não considera o efeito de diversas 
variáveis inerentes ao processo de conformação a frio comumente observadas em ambientes industriais, tais como, impacto, vibração, temperatura, variação de geometria do Blank, degradação do óleo, entre outras.

Tabela 5 - Descrição das amostras e respectivos parâmetros de rugosidade (Traduzido de PODGORNIK, 2012)

\begin{tabular}{|c|c|c|c|c|c|c|}
\hline \multirow{2}{*}{ Amostra } & \multirow{2}{*}{ Descrição } & \multicolumn{5}{|c|}{ Parâmetros de rugosidade $[\mu \mathrm{m}]$} \\
\hline & & $\mathrm{R}_{\mathrm{a}}$ & $\mathrm{R}_{\mathrm{q}}$ & $\mathrm{R}_{\mathrm{z}}$ & $\mathrm{R}_{\mathrm{sk}}$ & $R_{k u}$ \\
\hline \multicolumn{7}{|l|}{ Grupo I } \\
\hline $\mathrm{T}$ & Torneamento & $3.42 \pm 0.24$ & $4.09 \pm 0.23$ & $16.46 \pm 0.3$ & $0.37 \pm 0.06$ & $2.32 \pm 0.02$ \\
\hline CG & Retifica com acabamento grosseiro & $0.80 \pm 0.15$ & $1.02 \pm 0.19$ & $5.24 \pm 0.93$ & $0.19 \pm 0.11$ & $3.21 \pm 0.38$ \\
\hline FG & Retifica com acabamento fino & $0.13 \pm 0.01$ & $0.17 \pm 0.01$ & $1.10 \pm 0.06$ & $-0.39 \pm 0.24$ & $3.78 \pm 0.68$ \\
\hline \multicolumn{7}{|l|}{ Grupo II } \\
\hline T-P1 & $\mathrm{T}+$ polimento $(20 \mu \mathrm{m})$ & $2.65 \pm 0.24$ & $3.11 \pm 0.25$ & $12.07 \pm 1.0$ & $0.13 \pm 0.08$ & $2.07 \pm 0.06$ \\
\hline CG-P1 & CG + polimento $(20 \mu \mathrm{m})$ & $0.49 \pm 0.07$ & $0.61 \pm 0.06$ & $2.57 \pm 0.31$ & $0.16 \pm 0.12$ & $3.31 \pm 0.17$ \\
\hline FG-P1 & $\mathrm{FG}+$ polimento $(20 \mu \mathrm{m})$ & $0.10 \pm 0.01$ & $0.13 \pm 0.01$ & $0.79 \pm 0.08$ & $-0.47 \pm 0.13$ & $4.18 \pm 0.14$ \\
\hline \multicolumn{7}{|l|}{ Grupo III } \\
\hline T-P2 & T-P1 + polimento $(10 \mu \mathrm{m})$ & $1.69 \pm 0.07$ & $1.96 \pm 0.05$ & $7.54 \pm 0.41$ & $0.07 \pm 0.08$ & $2.11 \pm 0.21$ \\
\hline CG-P2 & CG-P1 + polimento $(10 \mu \mathrm{m})$ & $0.29 \pm 0.04$ & $0.37 \pm 0.06$ & $1.85 \pm 0.24$ & $-0.09 \pm 0.06$ & $3.28 \pm 0.31$ \\
\hline FG-P2 & FG-P1 + polimento $(10 \mu \mathrm{m})$ & $0.09 \pm 0.00$ & $0.12 \pm 0.01$ & $0.64 \pm 0.02$ & $-0.46 \pm 0.21$ & $4.29 \pm 0.77$ \\
\hline \multicolumn{7}{|l|}{ Grupo IV } \\
\hline T-SPS1 & $\begin{array}{l}\mathrm{T}+\text { shot peening } \\
\text { (esferas de aço } \varnothing 230 \mu \mathrm{m})\end{array}$ & $3.40 \pm 0.57$ & $4.15 \pm 0.72$ & $18.28 \pm 2.6$ & $0.01 \pm 0.05$ & $2.63 \pm 0.05$ \\
\hline CG-SPS1 & $\begin{array}{l}\text { CG + shot peening } \\
\text { (esferas de aço Ø230 } \mu \mathrm{m})\end{array}$ & $2.25 \pm 0.04$ & $2.96 \pm 0.12$ & $14.86 \pm 0.1$ & $-0.77 \pm 0.36$ & $4.76 \pm 0.64$ \\
\hline FG-SPS1 & $\begin{array}{l}\text { FG + shot peening } \\
(\text { esferas de aço Ø230 } \mu \mathrm{m})\end{array}$ & $1.31 \pm 0.07$ & $1.97 \pm 0.09$ & $11.71 \pm 0.6$ & $-1.72 \pm 0.07$ & $8.68 \pm 0.52$ \\
\hline FG-SPS2 & $\begin{array}{l}\text { FG + shot peening } \\
\text { (esferas de aço Ø150 } \mu \mathrm{m})\end{array}$ & $0.66 \pm 0.03$ & $1.00 \pm 0.08$ & $6.38 \pm 0.49$ & $-2.11 \pm 0.15$ & $12.78 \pm 0.9$ \\
\hline FG-SPC1 & $\begin{array}{l}\text { FG + shot peening } \\
(\text { esferas de cerâmica Ø230 } \mu \mathrm{m})\end{array}$ & $2.25 \pm 0.21$ & $2.82 \pm 0.28$ & $14.08 \pm 1.2$ & $-0.29 \pm 0.10$ & $3.26 \pm 0.36$ \\
\hline FG-SPC2 & $\begin{array}{l}\text { FG + shot peening } \\
\text { (esferas de cerâmica } \varnothing 150 \mu \mathrm{m} \text { ) }\end{array}$ & $2.06 \pm 0.03$ & $2.59 \pm 0.01$ & $12.98 \pm 0.7$ & $-0.26 \pm 0.05$ & $3.17 \pm 0.33$ \\
\hline \multicolumn{7}{|l|}{ Grupo V } \\
\hline FG-T1 & $\begin{array}{l}\text { FG-P2 + LST } \\
\text { (densidade 1\%, } 500 \mu \mathrm{m} \text { ) }\end{array}$ & $0.06 \pm 0.00$ & $0.07 \pm 0.00$ & $0.44 \pm 0.06$ & $-0.18 \pm 0.04$ & $3.91 \pm 1.44$ \\
\hline FG-T2 & $\begin{array}{l}\text { FG-P2 + LST } \\
\text { (densidade } 5 \%, 500 \mu \mathrm{m} \text { ) }\end{array}$ & $0.07 \pm 0.00$ & $0.09 \pm 0.01$ & $0.48 \pm 0.02$ & $-0.10 \pm 0.14$ & $3.16 \pm 0.35$ \\
\hline FG-T3 & $\begin{array}{l}\text { FG-P2 + LST } \\
\text { (densidade 20\%, } 500 \mu \mathrm{m} \text { ) }\end{array}$ & $0.08 \pm 0.01$ & $0.10 \pm 0.01$ & $0.55 \pm 0.02$ & $-0.08 \pm 0.06$ & $3.19 \pm 0.42$ \\
\hline
\end{tabular}

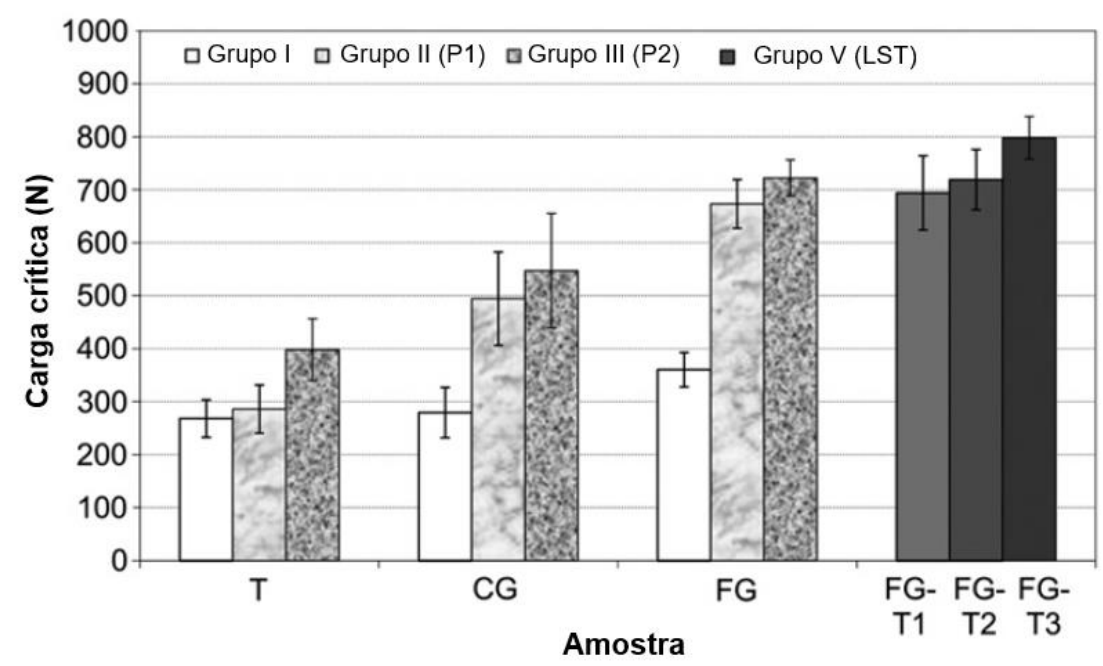

Figura 36 - Efeito da preparação superficial na carga crítica para transferir o aço inoxidável para o cilindro de aço ferramenta D2 em deslizamento lubrificado (PODGORNIK, 2012) 
Um outro trabalho publicado em 2011 pelo Lehrstuhl für Fertigungstechnologie (LFT) da Friedrich Alexander Universität Erlangen-Nürnberg foi elaborado com forte participação das indústrias alemãs, as quais são referências na área de conformação mecânica (ThyssenKrupp Presta, Hirschvogel, Strecon, Wezel e Räuchle), sobre soluções para ferramentas de conformação a frio (ENGEL et al., 2011). Os autores comentam que é sabido que a rugosidade superficial influencia significativamente na vida das ferramentas, sendo que polir as superfícies funcionais de punções e matrizes é essencial para reduzir o atrito, aumentar a durabilidade das ferramentas e garantir um bom acabamento superficial no produto conformado. Além disso, para casos de produção em massa de ferramentas, os autores recomendam que o polimento seja feito por máquinas automáticas assistidas por robô, com o intuito de evitar efeitos indesejáveis, tais como: variação na qualidade do polimento, variação na vida útil das ferramentas e dependência das habilidades manuais dos operadores. A Figura 37 apresenta uma máquina de polir assistida por robô, disponibilizada para o mercado a partir de 2010, e uma ferramenta polida com o auxílio dessa tecnologia. De acordo com os autores, esse tipo de máquina é capaz de atingir facilmente valores de rugosidade $R_{a}$ entre $0,015 \mu \mathrm{m}$ e $0,045 \mu \mathrm{m}$, os quais, segundo os autores, são tidos como ideais para ferramentas de conformação a frio.

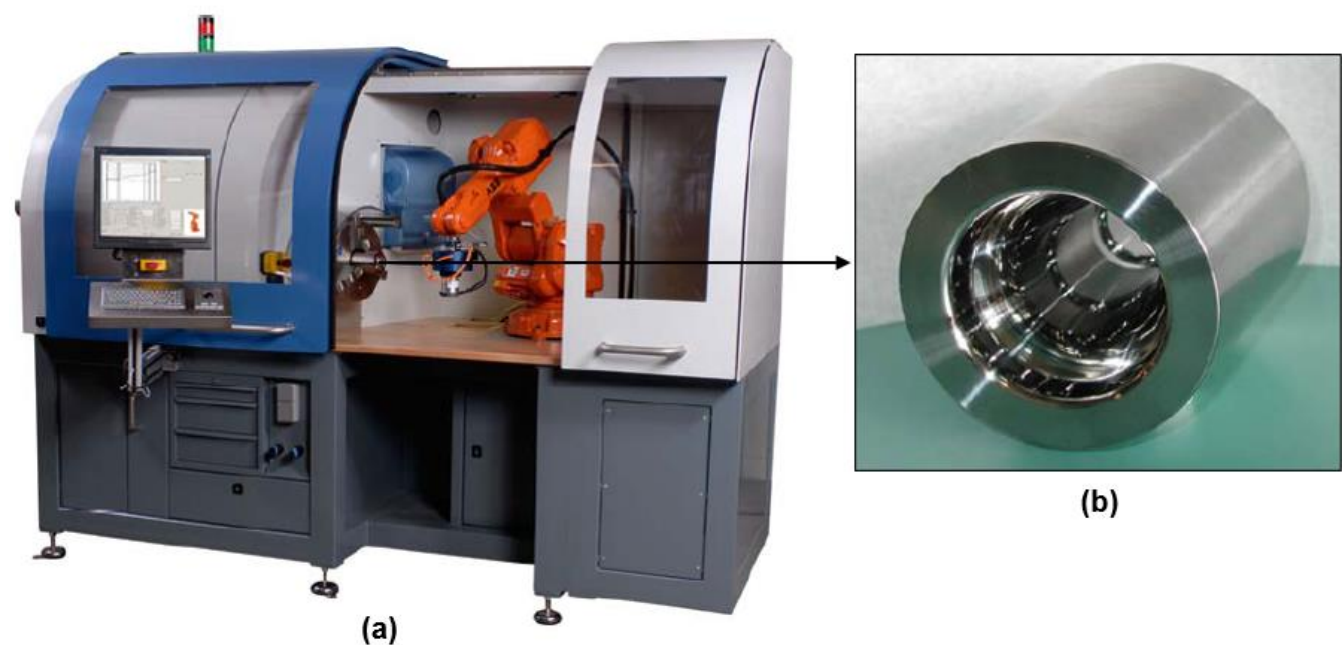

Figura 37 - (a) Máquina de polir assistida por robô; (b) Exemplo de ferramenta polida para operações de conformação a frio (GROENBAEK, 2008)

Em contraste aos trabalhos apresentados por Zum Gahr (1987), Sedlacek (2009), Podgornik (2015) e Engel et al. (2011), Mário Lopes Magri (MAGRI, 2011) mostrou que para um caso de forjamento vertical a quente em matriz aberta, as 
matrizes mais rugosas apresentaram o menor desgaste (matriz na condição 1 da Figura 38). Para isso, ele construiu matrizes com os quatro tipos de topografia apresentados na Figura 38 e analisou as superfícies após 50 e 125 ciclos de conformação. O parâmetro de amplitude usado para avaliar a rugosidade foi o $S_{z}$. Além do $S_{z}$, o autor analisou diversos outros parâmetros de rugosidade que não serão mencionados aqui.

\section{Tribossistema:}

a) Corpo: Matriz em aço H13

b) Contra-corpo: Blank em aço SAE 1020

c) Meio interfacial: Grafite em pó

d) Meio circunvizinho: $\mathrm{Ar}$

Topografia das matrizes:

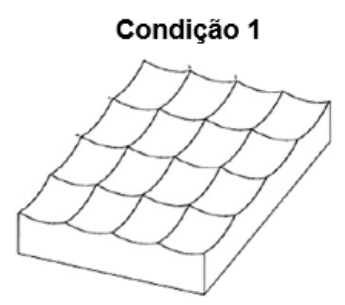

Sz $\sim 11,5$ um
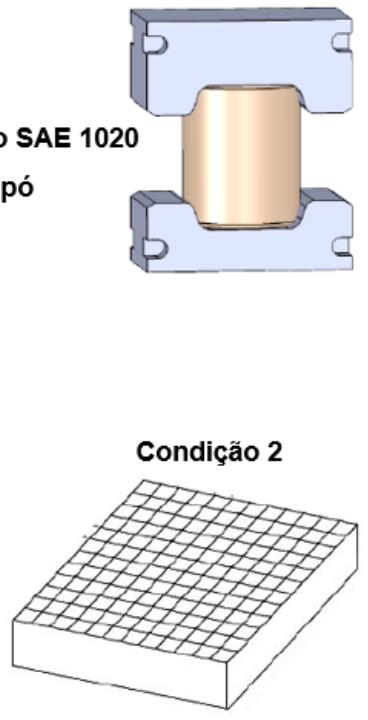

$S z \sim 5,2$ um
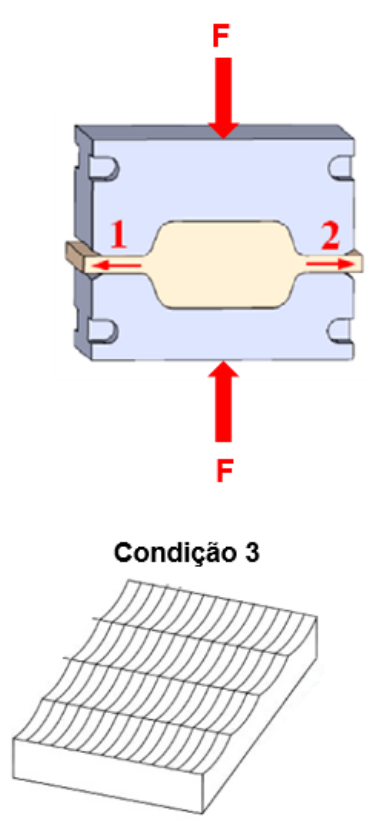

Sz 7,1 um

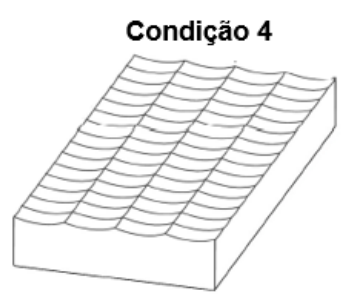

$\mathrm{Sz} \sim 7,1 \mathrm{um}$

Figura 38 - Tribossistema analisado por Magri e tipos de topografias das ferramentas (Adaptado de MAGRI, 2011)

A Figura 39 sintetiza a análise feita por Magri para as quatro condições de superfície antes e após 50 ciclos de conformação. As topografias após 125 ciclos não foram apresentadas por se assemelharem muito às superfícies após 50 ciclos. $A$ matriz fabricada com a condição 1 apresentou um ligeiro desgaste na região com maior movimento relativo em relação ao contra-corpo, sendo ainda possível identificar a topografia inicial da superfície após 50 ciclos de conformação, ou seja, as cavidades formadas durante a usinagem não foram totalmente removidas. A superfície fabricada na condição 2 foi quase totalmente desgastada após 50 ciclos de conformação, sendo possível observar a topografia inicial em poucas áreas da matriz. As matrizes fabricadas nas condições 3 e 4 apresentaram desgaste intermediário, ou seja, a área desgastada foi maior do que a condição 1 e menor do que a condição 2. 


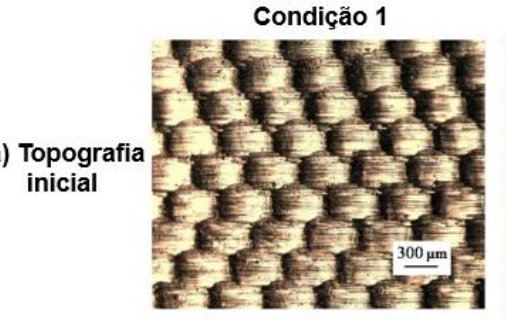

(b) Após 50

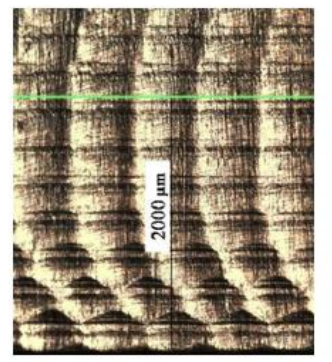

Condição 2
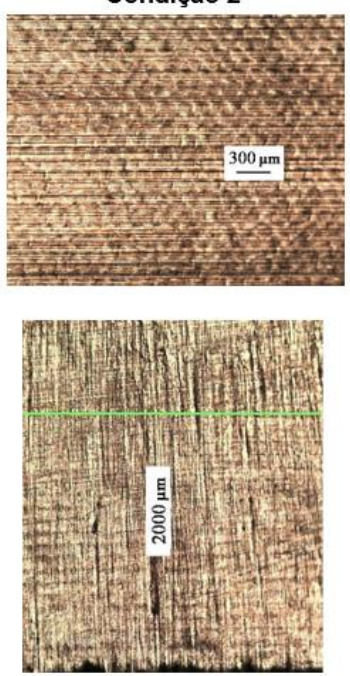

Condição 3
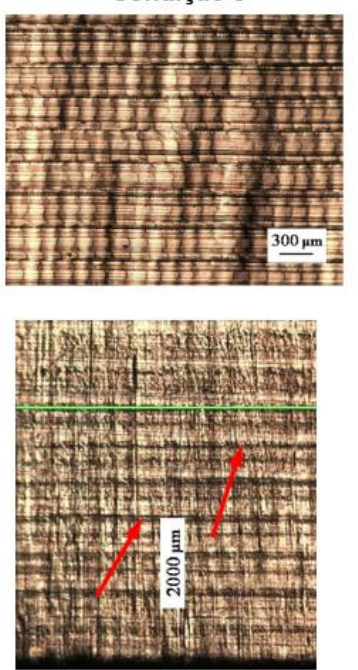

Condição 4
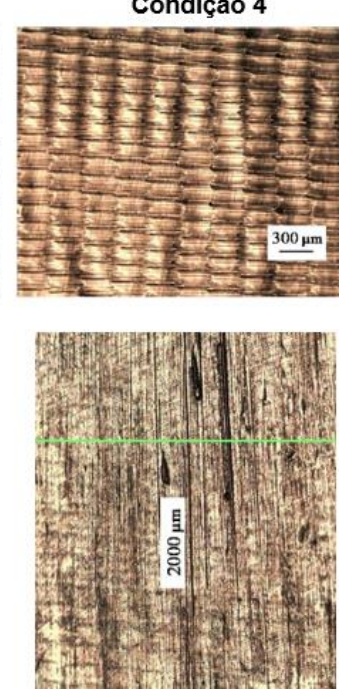

Figura 39 - Comparativo da topografia das matrizes nas 4 condições analisadas. (a) Antes da conformação e (b) após 50 ciclos (Adaptado de MAGRI, 2011)

Por meio de comparações visuais feitas com o auxílio de microscopia eletrônica de varredura, Magri concluiu que nem sempre "a ferramenta mais lisa é a melhor". O autor explica que a matriz mais rugosa apresentou menor desgaste devido a esta apresentar maior potencial para reter o lubrificante, o que evita o contato direto entre asperezas, mantendo o regime de lubrificação hidrodinâmico e consequentemente reduzindo o coeficiente de atrito entre as ferramentas. Ou seja, para esse tribossistema particular foi possível combinar uma manufatura de ferramenta mais simples e mais barata com redução do desgaste.

Portanto, com base nos resultados obtidos por Magri (2011) e por Schey (1984), é possível que exista um potencial de melhoria e redução de custo no processo de fabricação das ferramentas de conformação a frio, podendo ser uma otimização em alguma fase do processo ou idealmente eliminando alguma das fases existentes as quais visam diminuir a rugosidade, como o polimento por exemplo. Esse potencial de redução de custo foi o que financiou essa pesquisa em um ambiente industrial. 


\section{MATERIAIS E MÉTODOS}

Este trabalho foi conduzido com base no acompanhamento de diversos lotes de produção e observações feitas in loco na empresa Neumayer Tekfor Automotive Brasil Ltda., localizada em Jundiaí - SP, entre Março de 2015 e Julho de 2016, totalizando 1.224 .000 peças produzidas. A empresa tem em sua essência a fabricação de componentes automotivos pelos processos de conformação a frio e a quente seguidos ou não de usinagem e tratamento térmico.

\subsection{Apresentação e caracterização do tribossistema}

No presente trabalho foi utilizada uma prensa mecânica excêntrica multiestágios de forjamento horizontal, onde são fabricados os produtos conformados a frio. As Figuras 40 e 41 apresentam, respectivamente, o exterior e o interior da máquina utilizada no estudo.

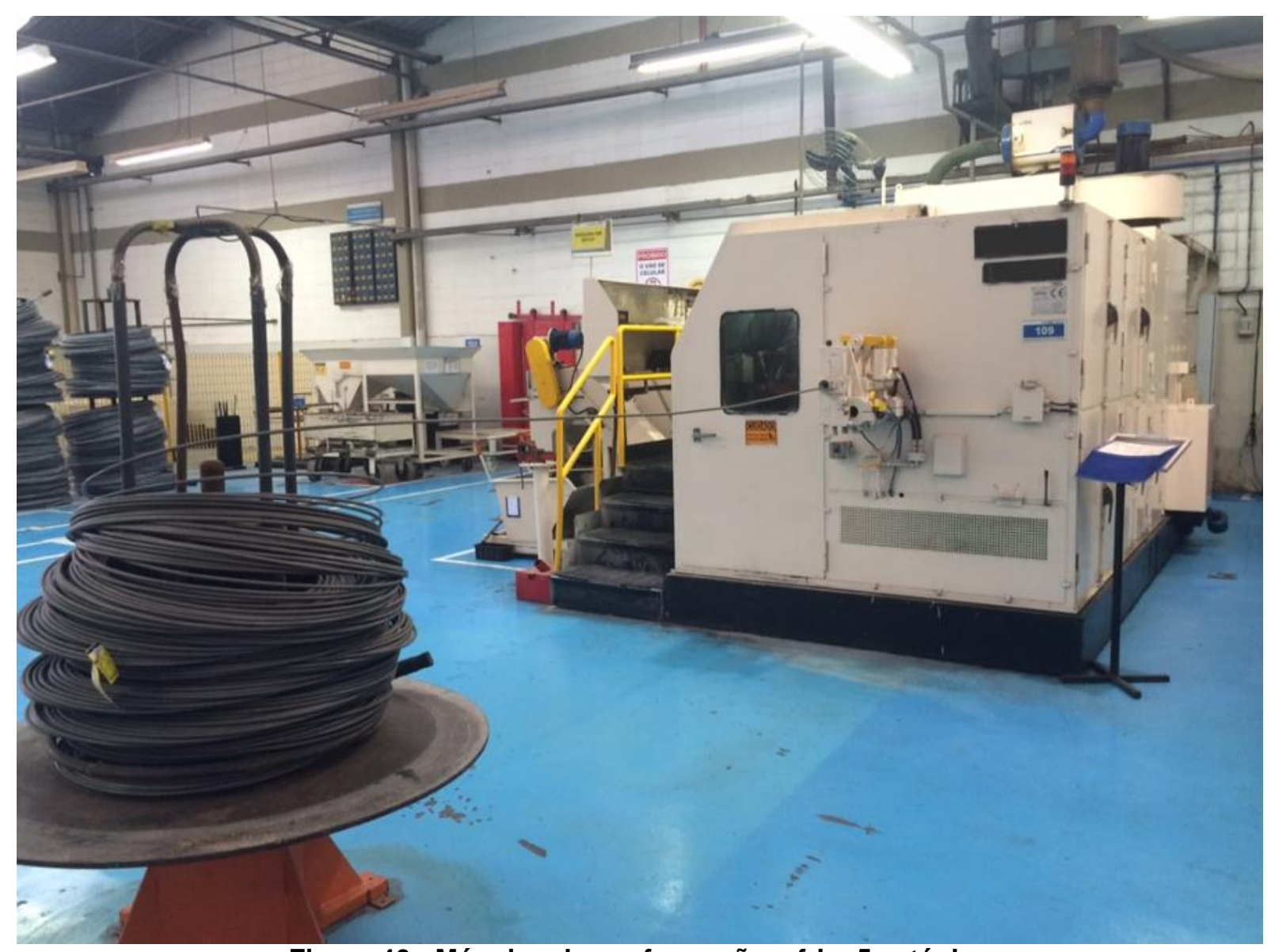

Figura 40 - Máquina de conformação a frio, 5 estágios 


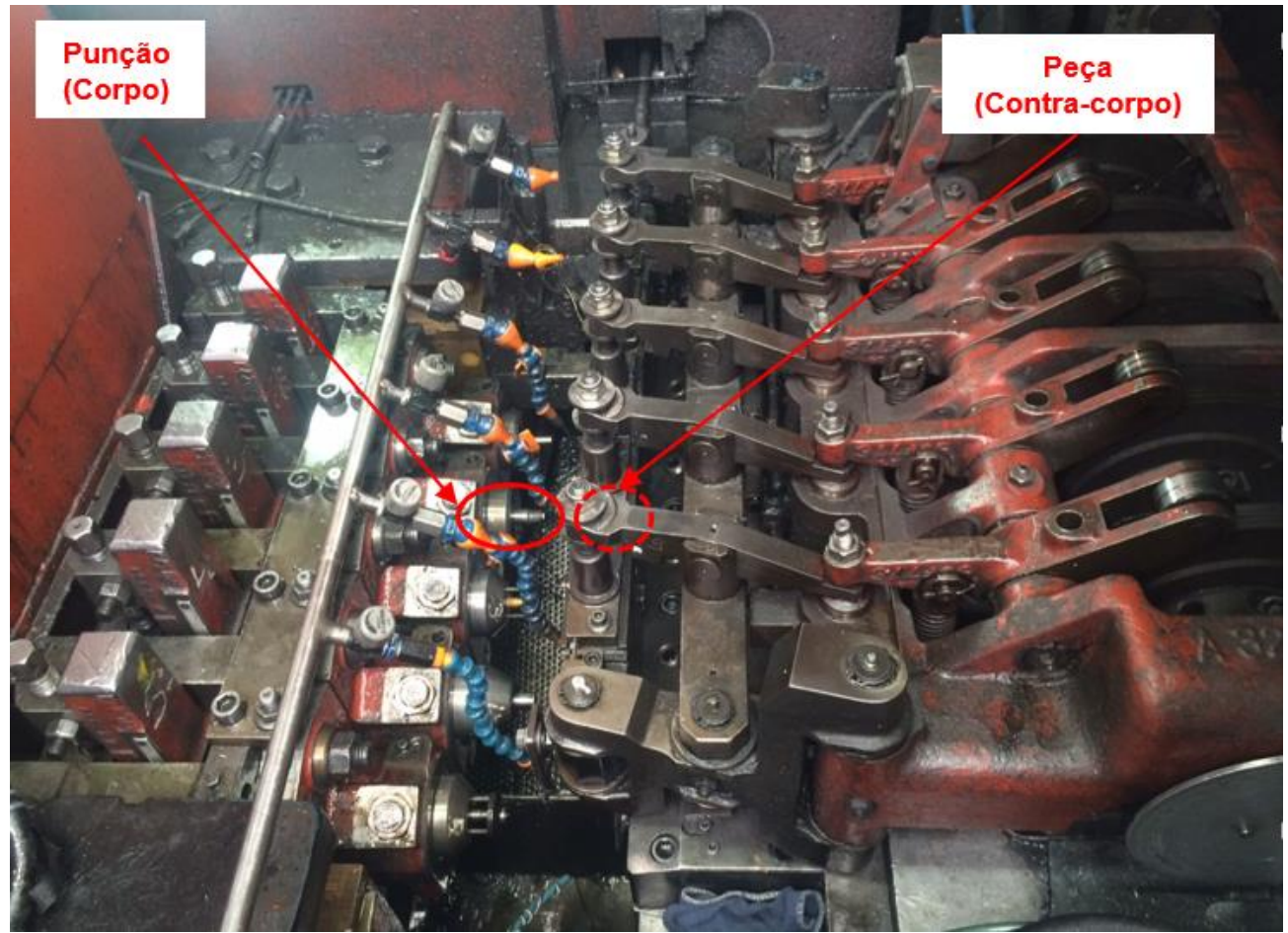

Figura 41 - Interior da máquina

Entre os produtos fabricados na máquina selecionada para este estudo, foi selecionada a porca chapéu apresentada na Figura 42, com aplicação em motocicletas, por ser um item de alta demanda anual, além de apresentar um ferramental simples e similar a outros itens da fábrica. Além disso, o ferramental desse item é de fácil transporte devido ao seu tamanho e o projeto de engenharia não contempla aplicação de filmes finos como nitreto de titânio, uma variável adicional que teria que ser controlada durante o estudo.

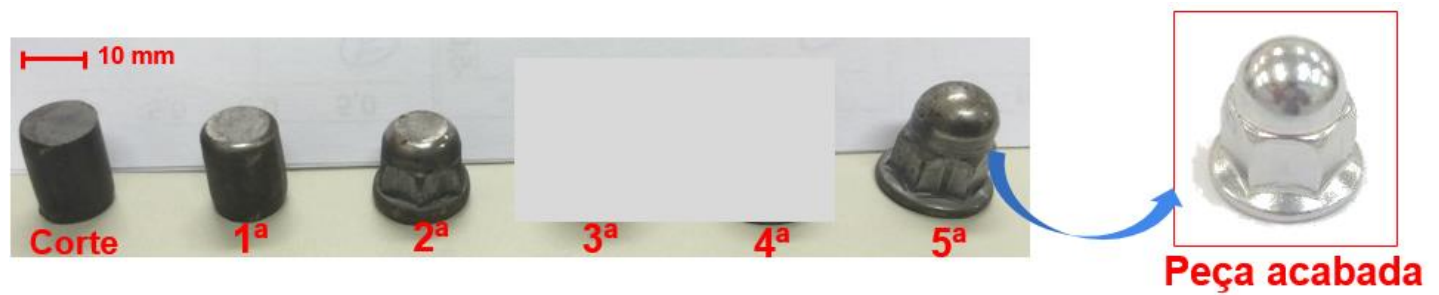

Figura 42 - Sequência de conformação do item analisado. As pré-formas de $3^{a}$ e $4^{a}$ operação foram escondidas por se tratar de know-how de fabricação da empresa TEKFOR

O objeto de estudo desde trabalho é um punção de segunda operação do tribossistema apresentado na Figura 43, onde o punção é o corpo, a matéria-prima ou peça é o contra-corpo, o meio interfacial é óleo e o meio circunvizinho é ar. 

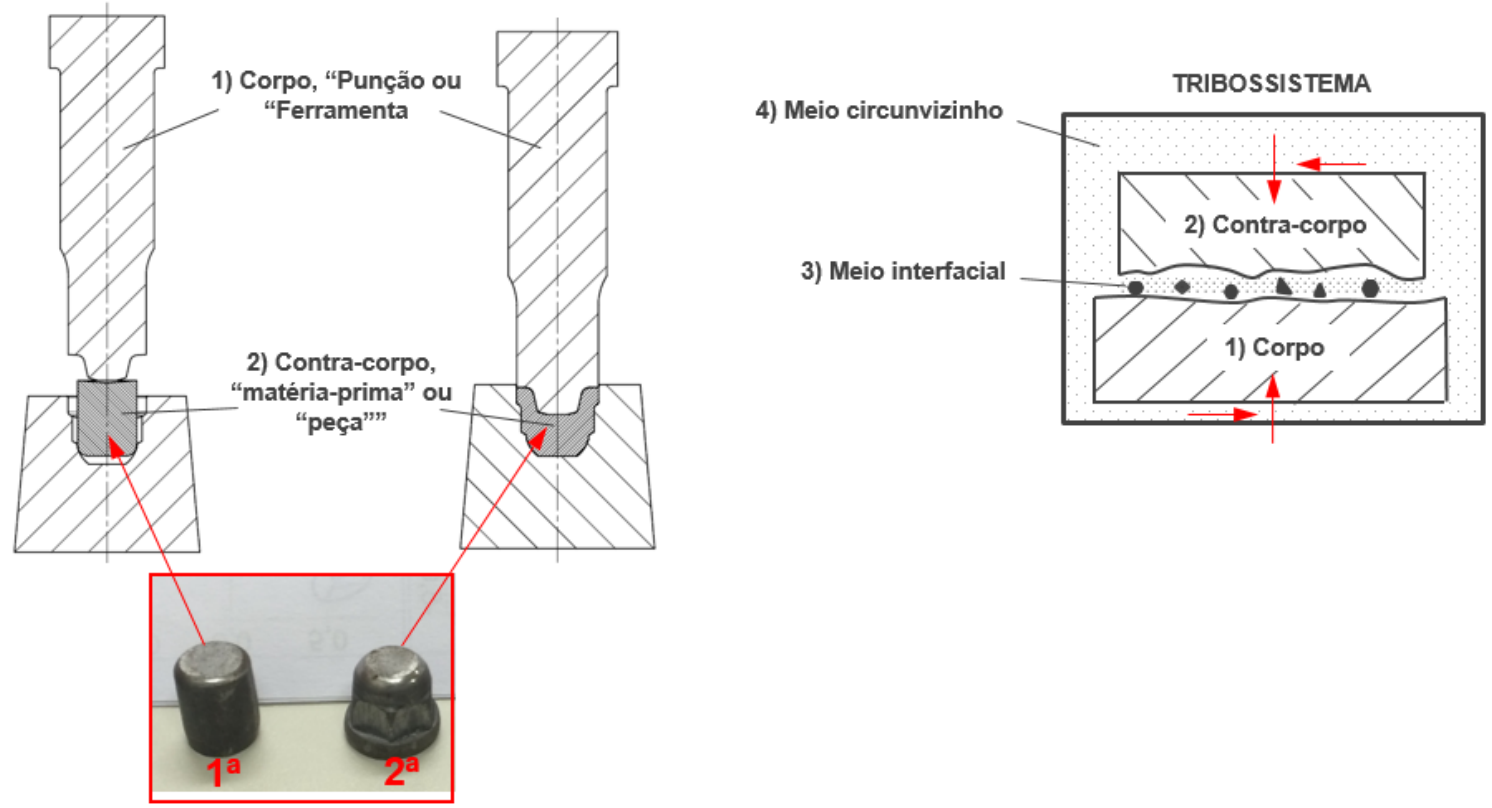

Figura 43 - Tribossistema analisado: 2a operação

\subsection{Caracterização da ferramenta ("punção" ou "corpo”)}

A Figura 44 apresenta os quinze punções confeccionados com três níveis de rugosidade variando em até uma ordem de grandeza, sendo cinco punções sem usinagem de acabamento gerando um $R_{a}$ entre 1,5 e 2,5 $\mu \mathrm{m}$, cinco punções com usinagem de acabamento e $R_{a}$ entre 0,5 e 0,8 $\mu$ m e cinco punções polidos com $R_{a}$ entre 0,1 e 0,3 $\mu \mathrm{m}$. Neste trabalho, os punções de 1 a 5 serão denominados "rugosos", os punções de 6 a 10 de "intermediários" e os punções de 11 a 15 de "polidos". Todos os punções foram usinados em tornos CNC a partir da mesma barra de aço e foram submetidos simultaneamente ao mesmo tratamento térmico. A ordem de entrada em máquina dos punções é a seguinte: 1,6,11,2,7,12,3,8,13 e assim sucessivamente. Essa ordem foi propositalmente escolhida para eliminar a influência de uma eventual variável não identificada na conclusão da relação entre topografia e desgaste de ferramenta. 


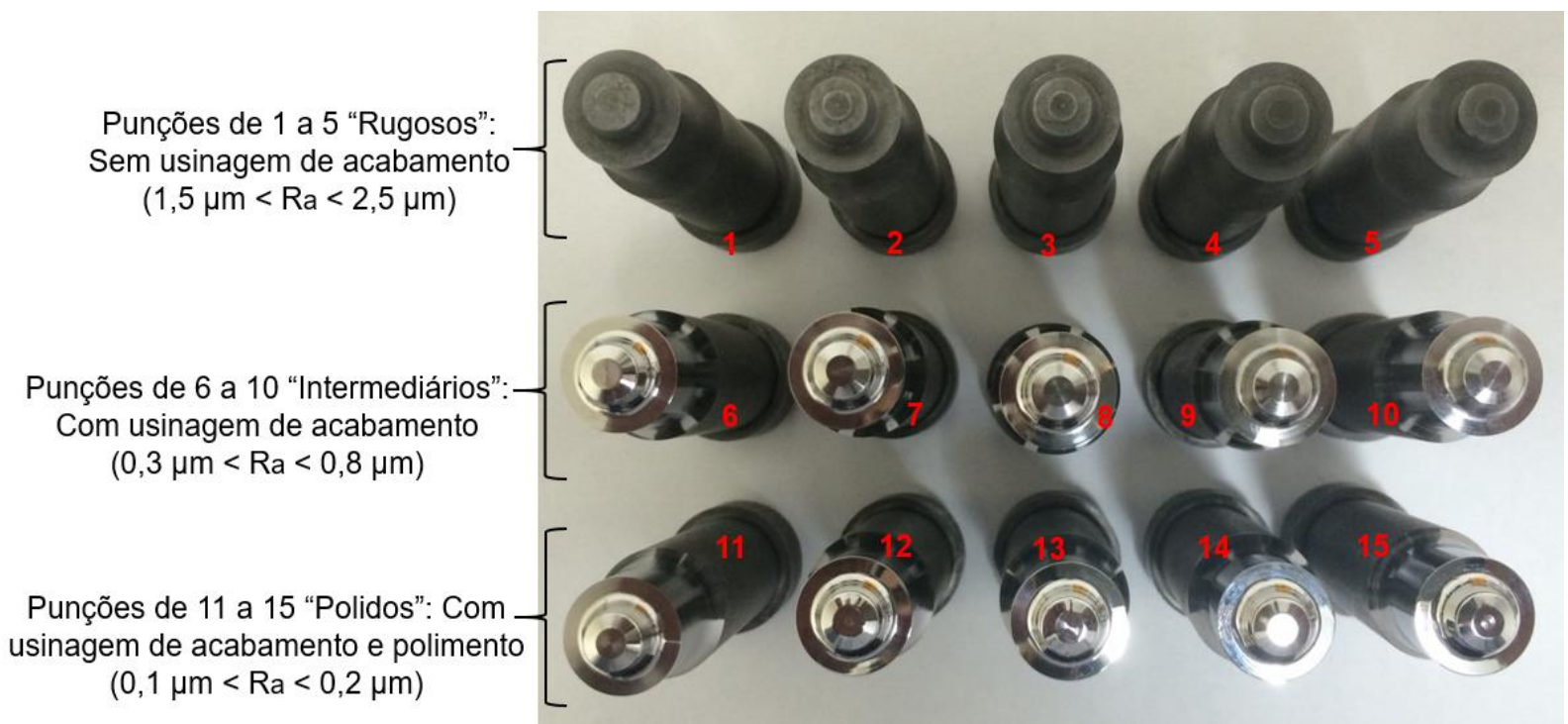

Figura 44 - Punções de 2a operação com topografias distintas utilizados no estudo

A Figura 45 apresenta os equipamentos utilizados na análise das ferramentas novas e usadas. Inicialmente todos os punções passaram por um processo de limpeza, iniciado com papel embebido com acetona, seguido de ultrassom e finalizado com jato de ar.

Após o procedimento de limpeza, as ferramentas foram pesadas em balança de precisão (a), seguido de análise dimensional em perfilômetro (b), análise da topografia em rugosímetro (c), análise da topografia em perfilômetro óptico (d) e análise da superfície em microscópio eletrônico de varredura (e). O ciclo de (a) até (e) foi repetido para todas as ferramentas após 52.000 e 102.000 ciclos de produção. As informações obtidas por meio desses métodos de ensaio são:

a) Balança: Perda de massa;

b) Perfilômetro de contato: Perda dimensional;

c) Rugosímetro: Rugosidade inicial;

d) Perfilômetro óptico: Rugosidade inicial e final;

e) Microscópio Eletrônico de Varredura (MEV): Dano superficial, tipos de desgaste e investigação de adesão. 

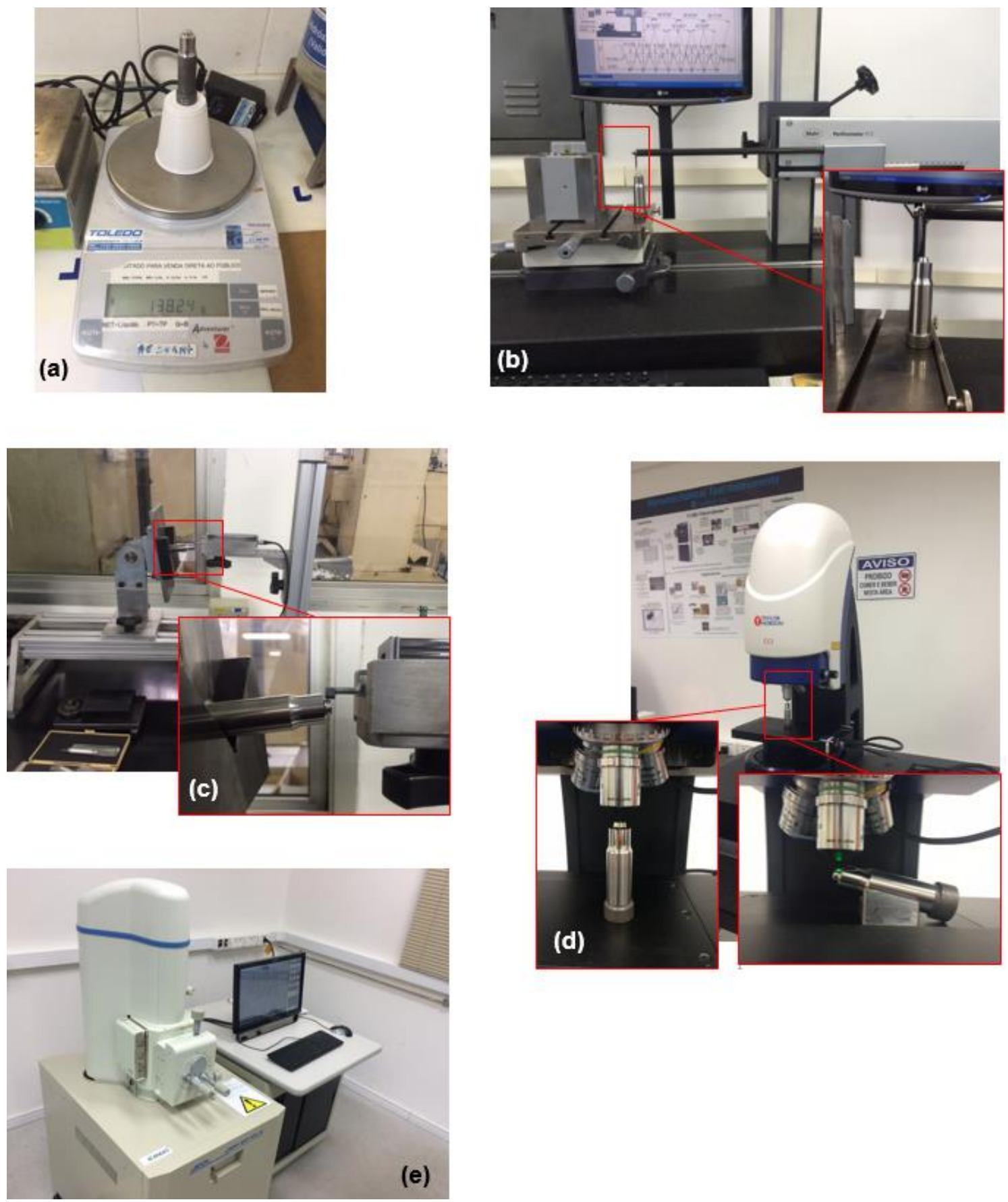

Figura 45 - Equipamentos utilizados a) Balança de precisão, b) Perfilômetro, c) Rugosímetro, d) Perfilômetro óptico 3D, e) Microscópio eletrônico de varredura

No caso da análise dimensional, todas as dimensões que poderiam sofrer alterações geométricas devido ao desgaste foram monitoradas. A Figura 46 apresenta a geometria do punção e as características monitoradas ao decorrer do trabalho. 


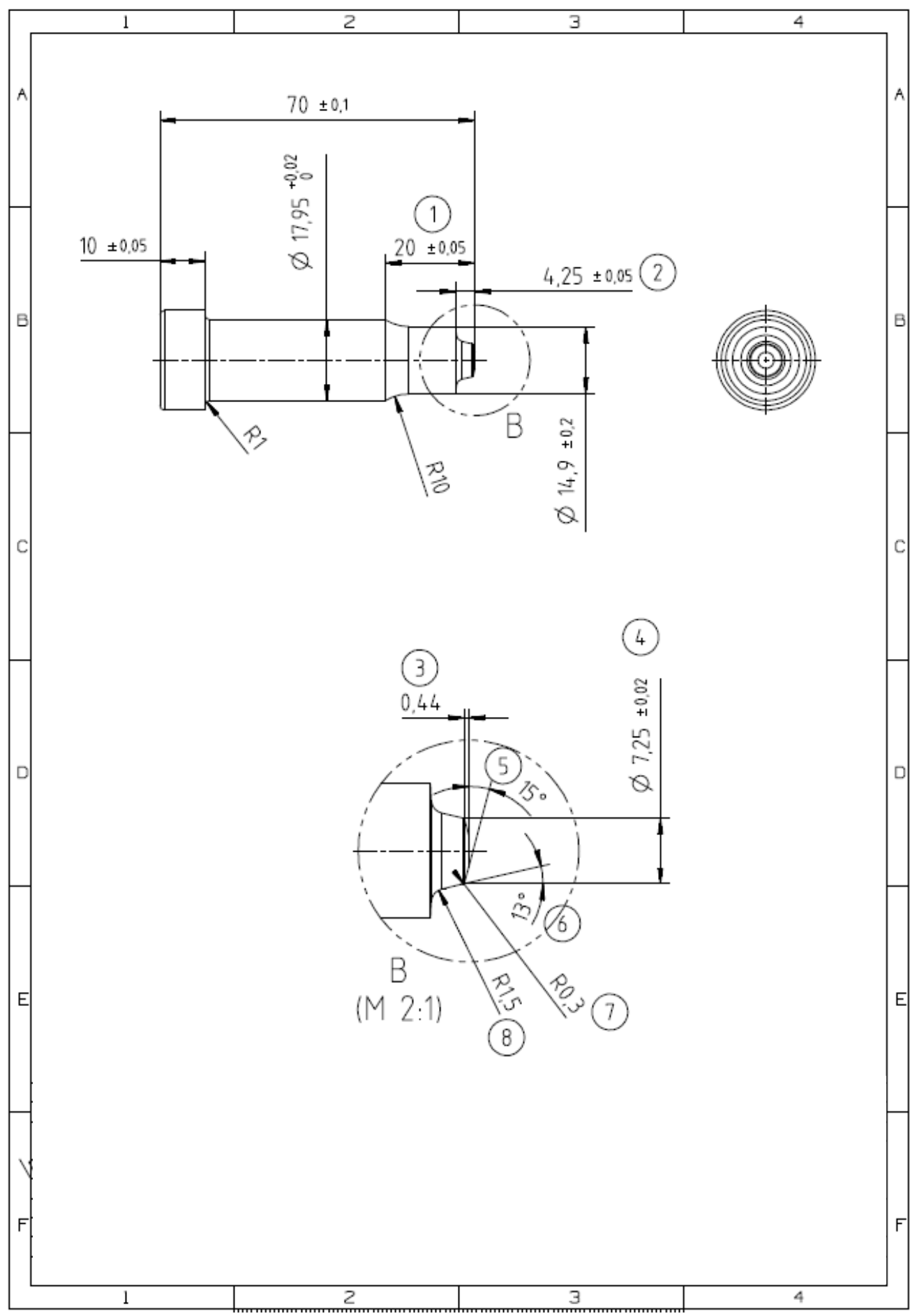

Figura 46 - Geometria do punção de segunda operação. As características de 1 a 8 sofrem desgaste ao longo da produção seriada e foram monitoradas ao decorrer do trabalho

As rugosidades do topo e da lateral da ferramenta foram medidas em um rugosímetro de agulha e em um perfilômetro óptico 3D, conforme mostrado na Figura 45. A Figura 47 mostra as regiões onde as rugosidades foram analisadas, sendo três medições no topo da ferramenta e três medições na lateral. Essas regiões foram escolhidas pois a dinâmica do contato tende a ser diferente durante 0 
processo de conformação, sendo que o topo está mais suscetível a altas pressões de contato enquanto na lateral é esperada maior tensão de cisalhamento gerada por atrito. Em função da diferença do tipo de carregamento causada pela geometria da ferramenta, o desgaste torna-se diferente nessas regiões.
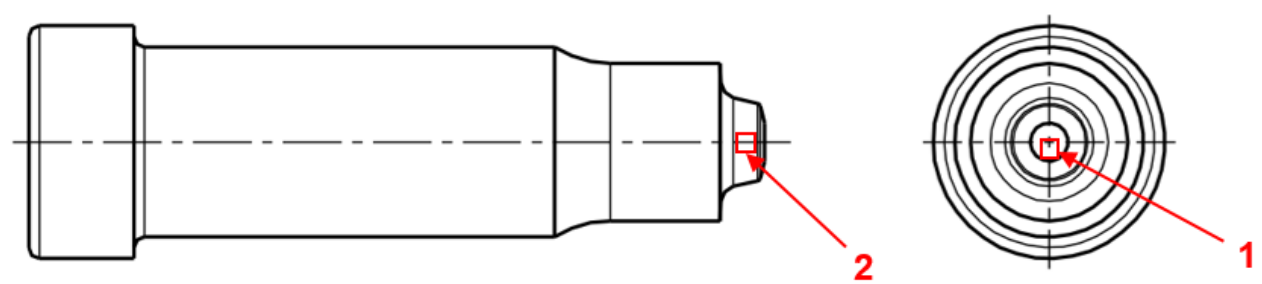

Figura 47 - Regiões de avaliação da rugosidade: (1) topo; (2) lateral

A matéria-prima utilizada na fabricação dos punções é o aço AISI M2, o qual é um aço ferramenta recomendado para fabricação de ferramentas para operações de corte e conformação a frio. Sua composição química, com a presença de tungstênio, molibdênio e vanádio garante a este material um nível de dureza elevado após o revenimento, garantindo retenção da capacidade de corte e das propriedades mecânicas durante o serviço. A composição química nominal do material utilizado para fabricação dos punções encontra-se na Tabela 6.

Tabela 6 - Especificação da composição química nominal do aço ferramenta AISI M2

\begin{tabular}{|c|c|c|c|c|}
\hline \multicolumn{5}{|c|}{ (\% em massa) } \\
\hline 1,00 & 4,15 & 5,00 & 1,95 & 6,40 \\
\hline
\end{tabular}

Todas as ferramentas foram submetidas simultaneamente aos tratamentos térmicos de têmpera e revenimento, de forma a conferir alta resistência mecânica e resistência ao desgaste. Para avaliar as propriedades mecânicas, foram realizados ensaios de dureza Vickers nas seções transversal e longitudinal do punção, conforme indicado na Figura 48. O equipamento utilizado foi um microdurômetro UHL VMHT, com uma carga de $500 \mathrm{gf}$, velocidade de ensaio de $50 \mu \mathrm{m} / \mathrm{s}$ e um espaçamento entre as medições de quatro vezes a diagonal da impressão, conforme norma ABNT NBR NM ISSO 6507-1:2008. 


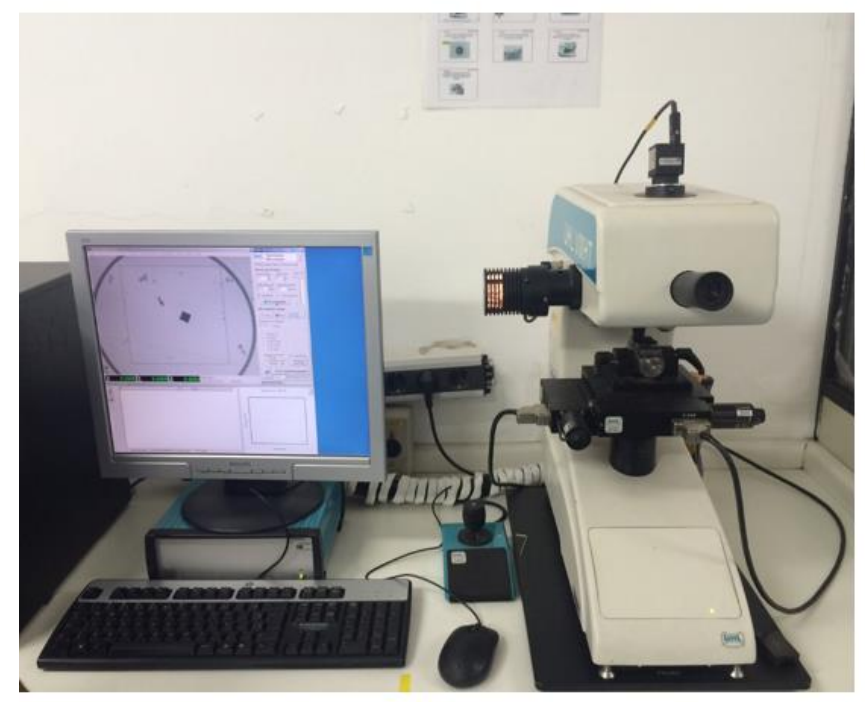

(a)

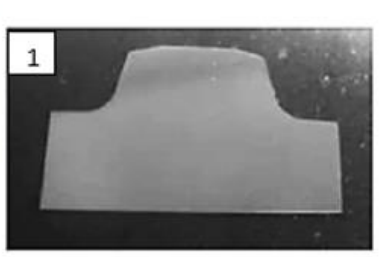

Seç̧ão AA

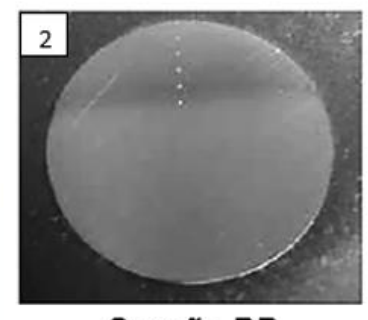

Secção BB

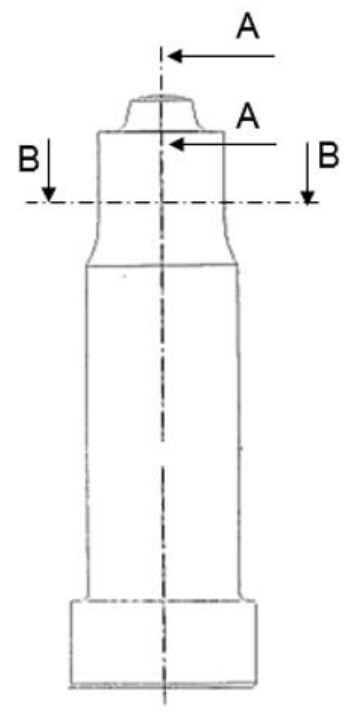

(b)

Figura 48 - a) Microdurômetro utilizado ; b) Regiões analisadas da ferramenta

A Figura 49 apresenta a variação de dureza do punção em função da distância da superfície. Graças aos processos de têmpera e revenimento a dureza oscilou entre $680 \mathrm{HV}$ e $730 \mathrm{HV}$, uma faixa típica de ferramentas de aço M2 temperadas e revenidas.
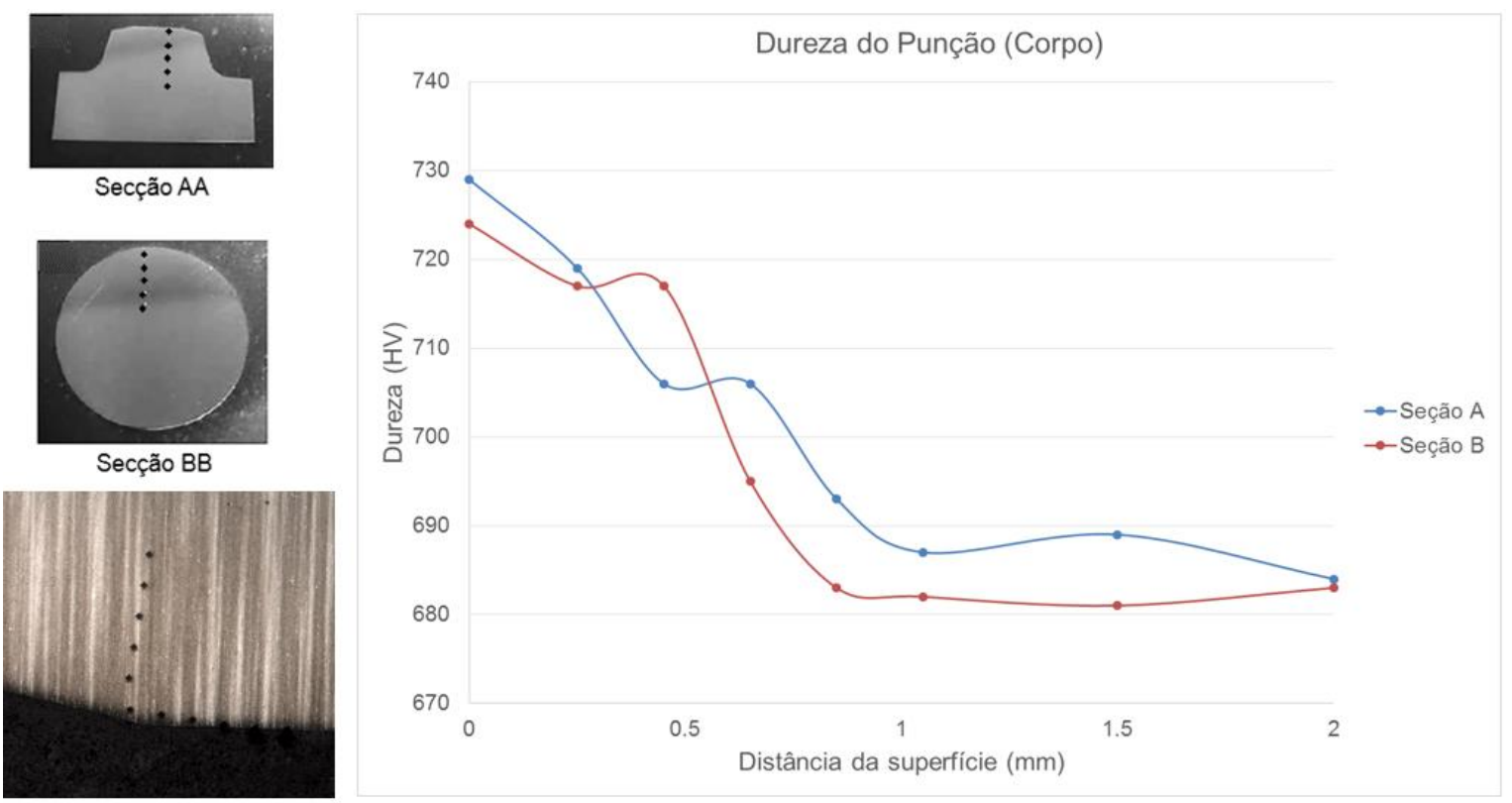

Figura 49 - Dureza do punção

Em seguida, foi realizada a análise metalográfica de uma amostra do punção para avaliar a microestrutura. Os resultados mostraram a presença de 
martensita revenida, com alinhamento de carbonetos na matriz conforme mostrado na Figura 50.

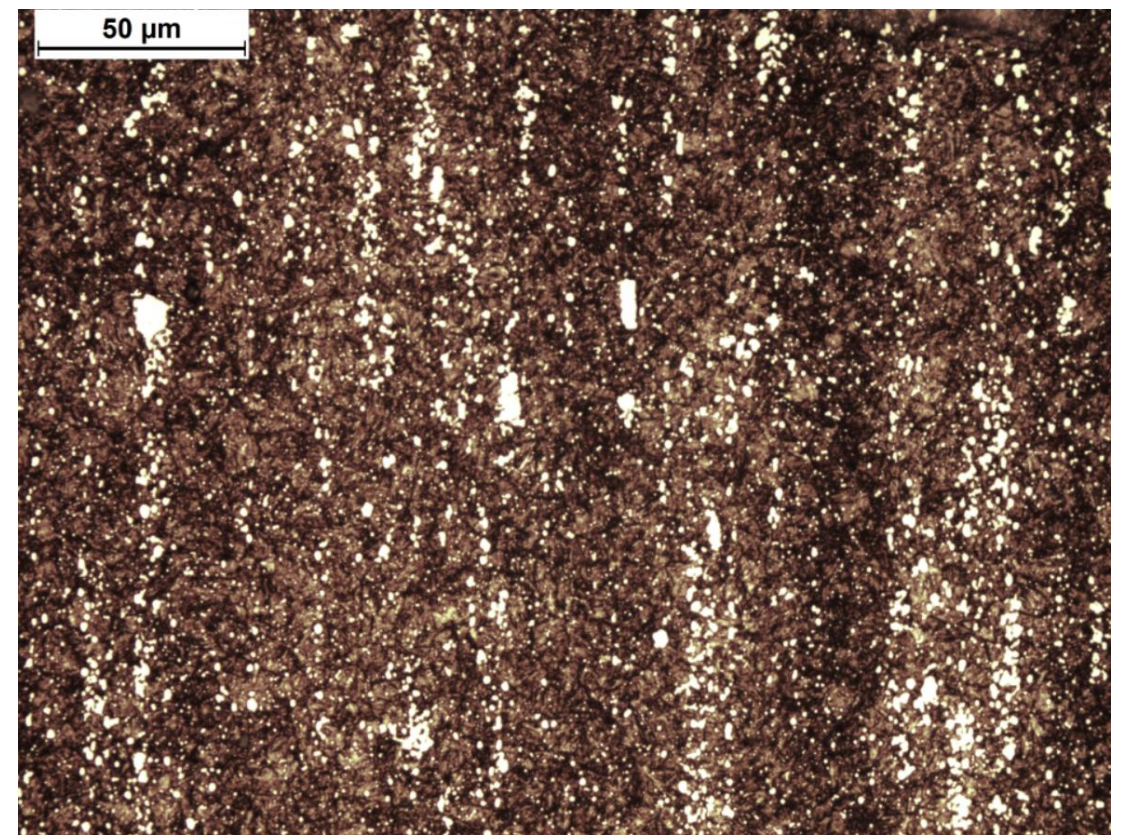

Figura 50 - Micrografia do punção em aço M2 temperado e revenido. Aumento de 500x. Ataque: Nital 3\%

\subsection{Caracterização da matéria-prima ("peça" ou "contra-corpo")}

A matéria-prima utilizada na fabricação da peça é o aço SAE 10B22. Esse material é um aço baixo carbono com adição de boro, com a especificação de composição química apresentada na Tabela 7.

Tabela 7 - Especificação da composição química do aço SAE 10B22 (\% em massa)

\begin{tabular}{|c|c|c|c|c|c|c|}
\hline & C & Mn & P & S & Si & B \\
\hline Mín. & 0,18 & 0,50 & Máx. & Máx. & 0,15 & 0,001 \\
\hline Máx. & 0,23 & 1,25 & 0,030 & 0,030 & 0,30 & 0,003 \\
\hline
\end{tabular}

Aços ao boro são muito utilizados na fabricação de fixadores e peças conformadas a frio que sofrem algum tipo de tratamento térmico durante seu processo de fabricação. 
Durante a conformação a frio, o material é submetido a um alto grau e taxa de deformação plástica. Para viabilizar o processo, é necessário um pré-tratamento da matéria-prima, de forma a garantir a conformabilidade adequada do material e minimizar os riscos de trincas e quebras de ferramentas. Soma-se a isso a necessidade de bitolas específicas que variam conforme a peça a ser produzida, sendo, portanto, comum a utilização do processo de beneficiamento apresentado na Figura 51.

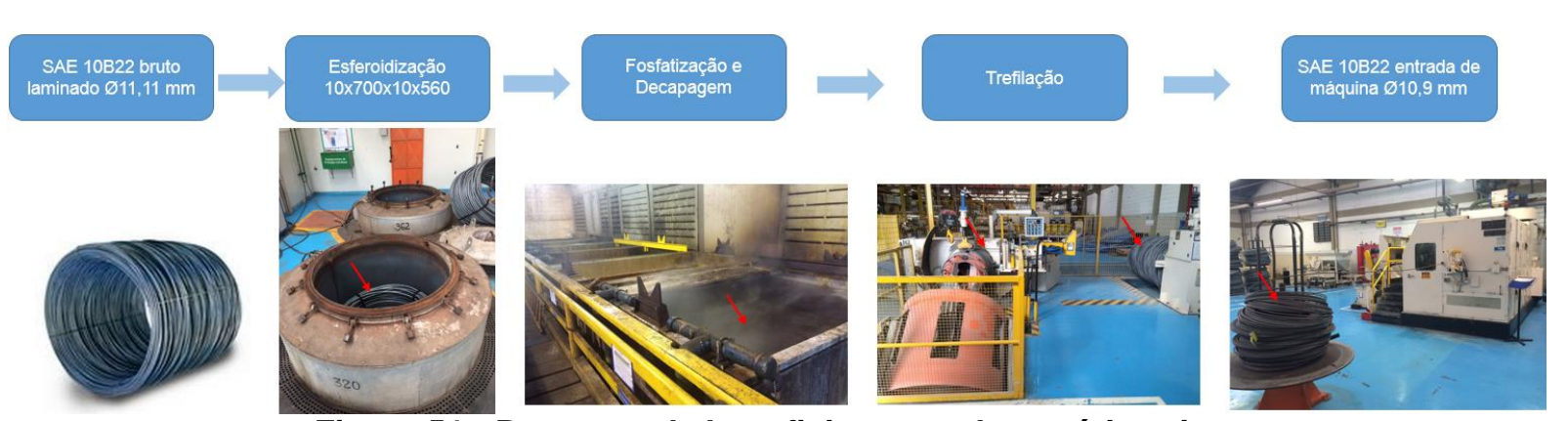

Figura 51 - Processo de beneficiamento da matéria-prima

Para analisar a influência do processo de beneficiamento nas propriedades da matéria-prima, foram conduzidos ensaios de tração, de dureza, metalografia e composição química no material na condição de entrada de máquina. Em função dos resultados desses ensaios, a matéria-prima pode ser utilizada na fabricação do item ou então deve ser destinada à fabricação de outro produto caso não atenda os critérios de qualidade especificados pela empresa. Com exceção da composição química, todas as outras propriedades dependem da eficiência do processo de beneficiamento apresentado na Figura 51. A composição química de cada corrida de aço SAE 10B22 utilizado na fabricação das peças foi validada por meio de um espectrômetro de absorção ótica e comparada com o certificado de qualidade disponibilizado pelo fabricante do aço na compra do fio máquina.

Além da análise da matéria-prima em condição de entrada de máquina, analisou-se também a variação de dureza do contra-corpo para verificar o aumento de dureza próximo à superfície devido ao encruamento gerado pelo processo de conformação. A Figura 52 apresenta as seções transversais da contra-peça medidas antes e após a segunda operação de conformação. Os losangos pretos ilustram as regiões aproximadas onde as impressões foram realizadas. 


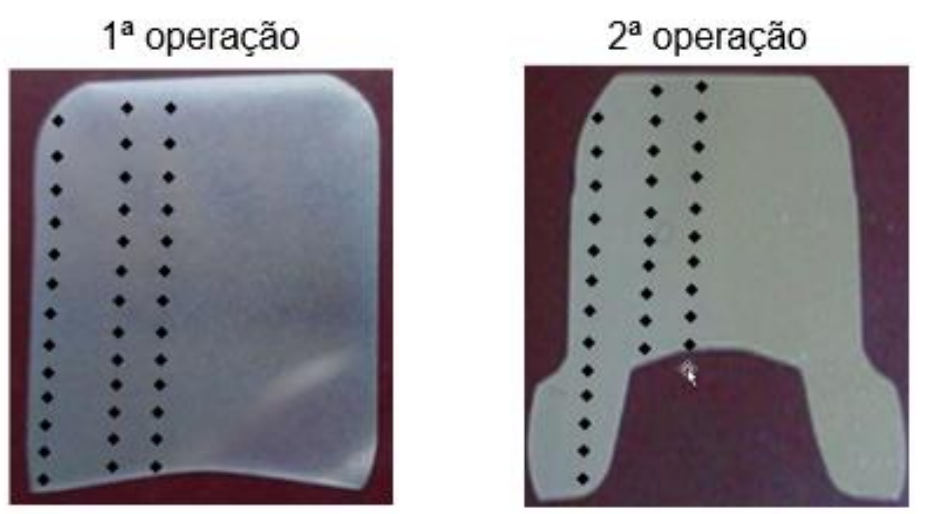

Figura 52 - Seção transversal da contra-peça e regiões de dureza medição de dureza

O mapeamento da dureza inicial da contra-peça, apresentado na Figura 53, revelou que o encruamento provocado pelo primeiro estágio da conformação gera um aumento de dureza de até $100 \mathrm{HV}$, sendo que a dureza próxima à superfície é de 200 HV enquanto o núcleo apresenta cerca de 95 HV. Ou seja, 200 HV é a máxima dureza da peça no instante inicial do contato com a ferramenta durante a segunda operação.
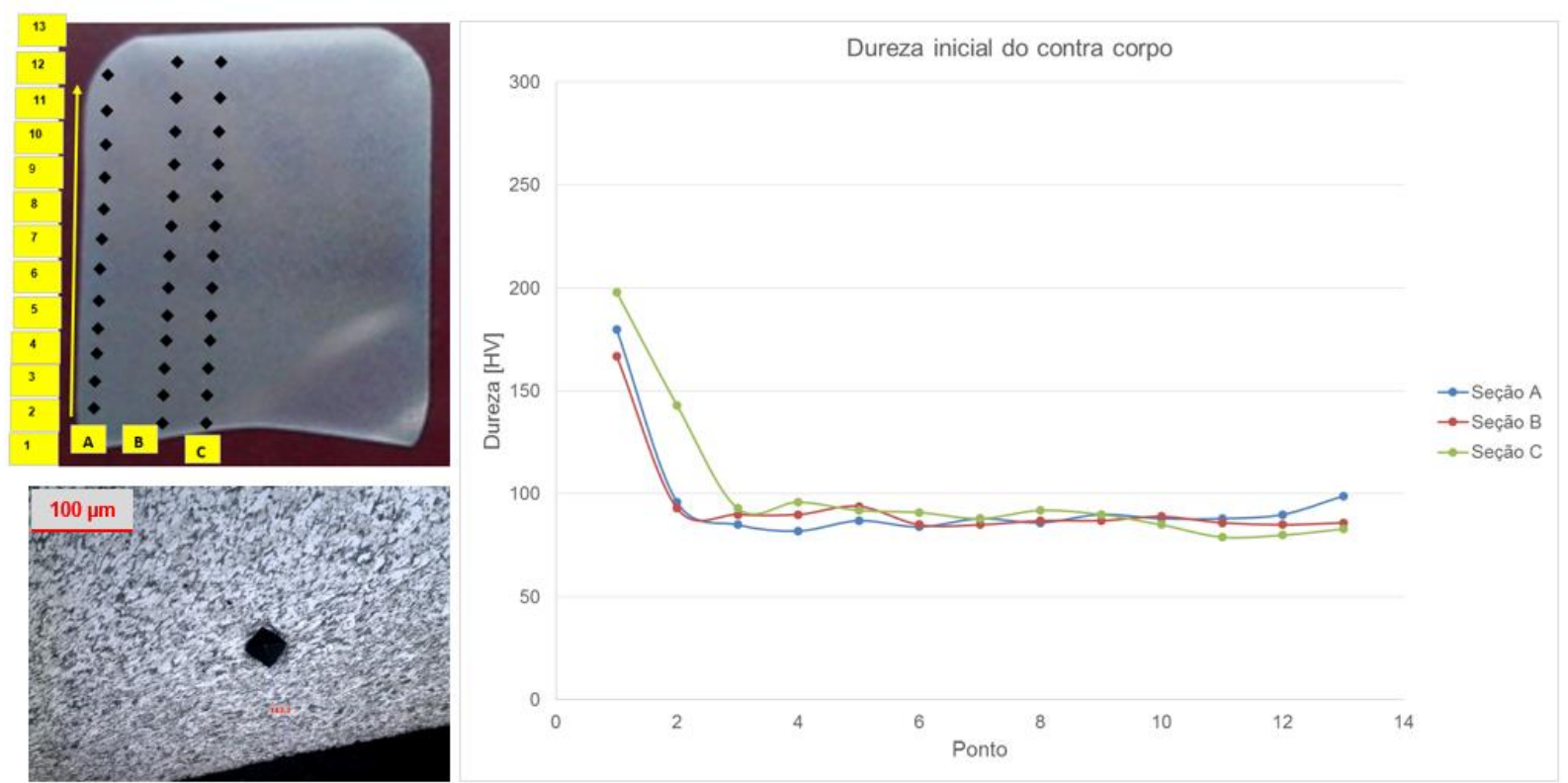

Figura 53 - Dureza da peça antes da $2^{\mathrm{a}}$ operação

A análise da microestrutura da matéria-prima contemplou o grau de esferoidização, o grau de dispersão e o tamanho de grão da matriz ferrítica. Estes fatores podem não apresentar relação direta com a dureza, entretanto são fundamentais para a tenacidade do material.

A ABNT estabelece que o grau de esferoidização deva ser determinado por meio da comparação da microestrutura, observada em um aumento de 500x, com os 
quadros-padrão indicados na norma ABNT NBR 14677. A Figura 54 apresenta a micrografia da matéria-prima na condição de entrada de máquina.

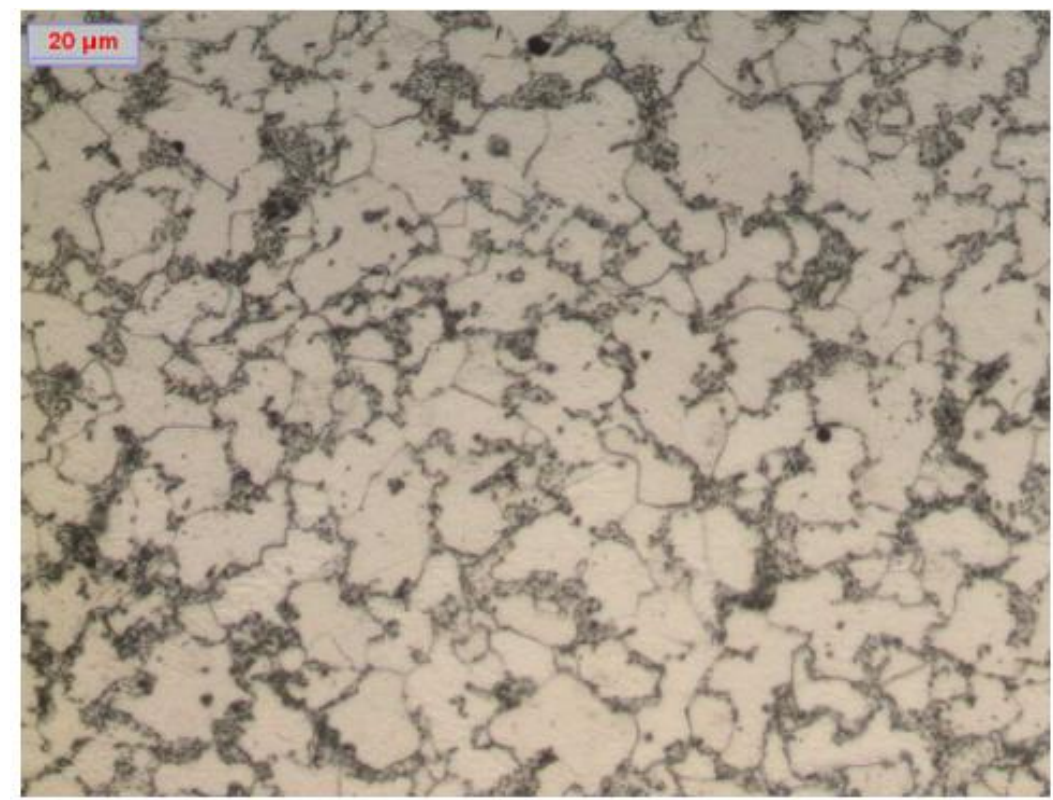

Figura 54 - Micrografia do material SAE10B22 após a esferoidização. Aumento de 500x. Ataque: Nital 3\%

Analisando a imagem, pode-se observar a presença de cementita esferoidizada dispersa na matriz ferrítica. Comparando a micrografia obtida com o padrão ABNT, conclui-se que a amostra apresentou um grau de esferoidização de $90 \%$. Já o grau de dispersão é medido de forma qualitativa e pode ser considerado como médio, pois existem cementitas concentradas nos contornos e no núcleo dos grãos.

Analisando a Figura 54 e comparando com os quadros padrão da norma ASTM E112, conclui-se que o tamanho de grão do material analisado é de 6 a 8 ASTM. A redução do tamanho de grão traz como consequência o aumento da resistência mecânica do material sem grandes perdas na ductilidade. Assim, para conformação a frio é prejudicial a presença de grãos grosseiros pois estes prejudicam a tenacidade do material. O valor encontrado nesta análise é considerado como típico para conformação a frio.

Após a análise das propriedades mecânicas, analisou-se também a topografia das peças fabricadas com os três tipos de punções (rugosos, intermediários e lisos), a fim de verificar se a diferença de rugosidade das ferramentas implicaria em alterações no regime de lubrificação ou na topografia do 
produto conformado. Para essa análise, foi utilizado o mesmo perfilômetro óptico 3D apresentado na Figura 45 (imagem d).

\subsection{Caracterização do meio interfacial "óleo"}

O óleo costuma ser o meio interfacial para a maioria das operações de conformação a frio, sendo que suas propriedades físicas, químicas, e nível de degradação influenciam diretamente a durabilidade das ferramentas. Apesar de sua importância inquestionável para o estudo do desgaste, a degradação do óleo é geralmente negligenciada nos testes de atrito e de degaste de corpos em contato lubrificado. O motivo disso é que na maioria dos casos, os testes acontecem em ambientes extremamente controlados como laboratórios ou bancadas de teste, onde o óleo está sempre novo ou com muito pouco uso, o que permite assumir que suas propriedades permaneçam constante ao longo do teste, de forma a viabilizar o estudo somente da variável de interesse (carga, velocidade, temperatura, rugosidade, etc.). Em um ambiente industrial, é economicamente inviável efetuar a troca do óleo e dos filtros das máquinas sempre que um produto é produzido. Por exemplo, na máquina utilizada nesse trabalho (Figura 40) o óleo é trocado de uma a duas vezes por ano dependendo da quantidade de peças produzidas. Como consequência, o óleo é uma variável que não foi possível "congelar" durante este trabalho, o que exigiu um monitoramento de suas propriedades ao longo dos lotes de produção. Além de suas propriedades físicas e químicas, investigou-se também se o óleo continha partículas sólidas que pudessem estar presentes no meio interfacial entre a ferramenta e a peça, o que certamente contribuiria para o desgaste das ferramentas. Para isso, coletaram-se $500 \mathrm{ml}$ do lubrificante para que as eventuais partículas fossem contadas conforme norma ISO 4406:1999. O óleo coletado foi homogeneizado por agitação e em seguida derramado sobre uma membrana filtrante de éster de celulose com diâmetro de $47 \mathrm{~mm}$ e poros de 1,2 $\mu \mathrm{m}$. A Figura 55 mostra o óleo coletado e o aspecto da membrana após a filtragem. A contagem de partículas foi realizada na membrana com o auxílio de um microscópio óptico. 
(a)

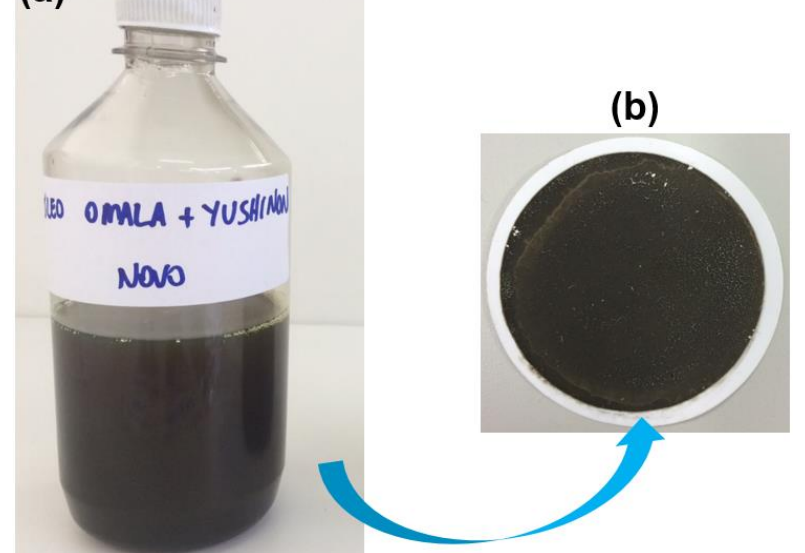

Figura 55 - (a) Óleo coletado e (b) membrana analisada após filtragem 


\section{RESULTADOS}

Foram fabricadas 1.224 .000 peças com as ferramentas analisadas neste trabalho, sendo que a Figura 56 mostra o estado das ferramentas após sucessivos ciclos de produção em série.

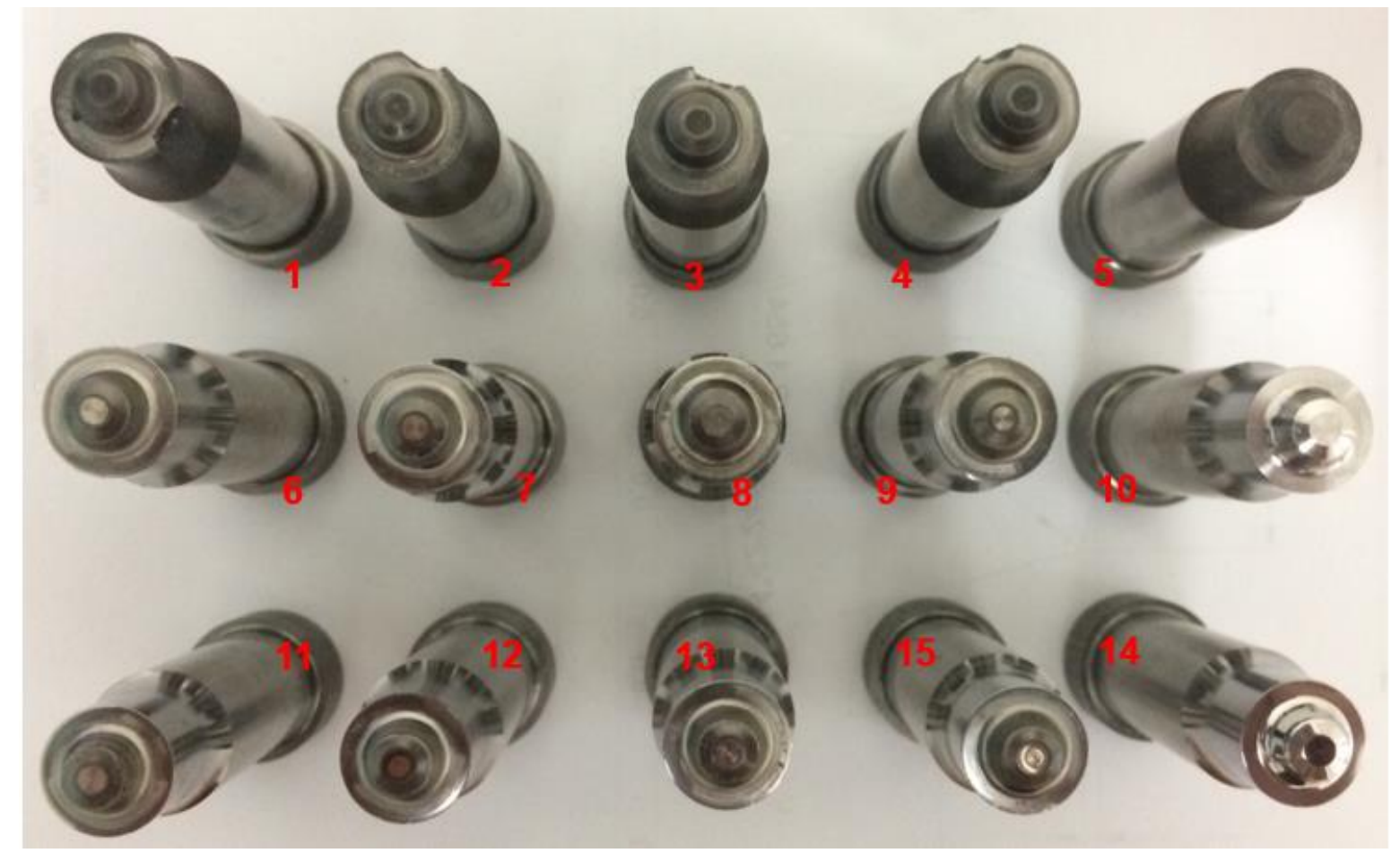

Figura 56 - Punções de 2⿳a operação após sucessívos lotes de produção

Todos os punções "rugosos" com $R_{a}$ entre 1,5 e 2,5 $\mu \mathrm{m}$ falharam prematuramente com menos de 102.000 ciclos, sendo que o modo de falha aparenta ser o mesmo. O punção 1 resistiu 52.000 ciclos, enquanto os punções 2, 3 e 4 resistiram $46.000,4.100$ e 5.500 ciclos, respectivamente. É provável que essa falha prematura, observada apenas nos punções "rugosos", esteja relacionada com a rugosidade inicial das ferramentas. Os punções "intermediários" 6, 7, 8 e 9, e os "polidos" 11, 12, 13 e 15 já foram submetidos a 102.000 ciclos. Os punções 5,10 e 14 foram propositalmente preservados para analisar o dano superficial após um número baixo de ciclos a ser determinado, possivelmente entre $0,1 \%$ e $1 \%$ da vida nominal do punção, a fim de verificar se após essa quantidade de ciclos o possível benefício gerado por uma superfície inicialmente mais lisa permanece válido. Uma vez que os punções "rugosos" não atingiram um número mínimo de ciclos que possibilitasse comparar seu desempenho tribológico com os demais punções, as 
análises subsequentes de perda de massa e perda de geometria serão apresentadas apenas para os punções "intermediários" e "polidos".

\subsection{Dureza}

Inicialmente, foi realizada a análise na peça após a segunda operação para verificar o efeito do encruamento gerado pelo forjamento. A Figura 57 mostra que a dureza chega à 248 HV próximo à superfície, ou seja, essa é a maior dureza do contra-corpo e que será utilizada na comparação com a dureza do punção (corpo).

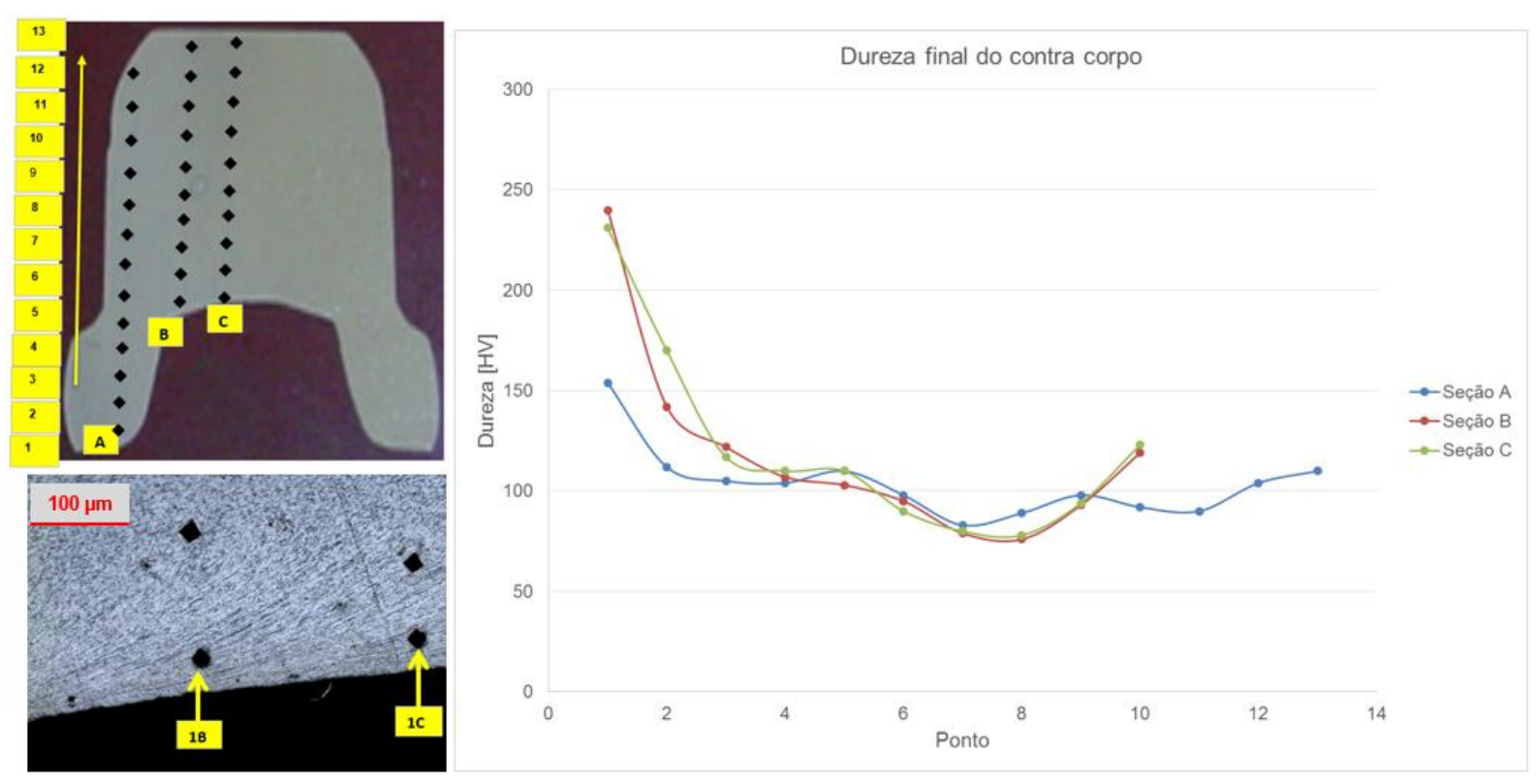

Figura 57 - Dureza da peça após a $2^{\mathrm{a}}$ operação

A Figura 58 apresenta um comparativo entre a dureza do punção com a da peça. Observa-se que a diferença na superfície é de aproximadamente $483 \mathrm{HV}$, ou seja, a dureza do punção é quase três vezes maior do que a dureza da peça. 


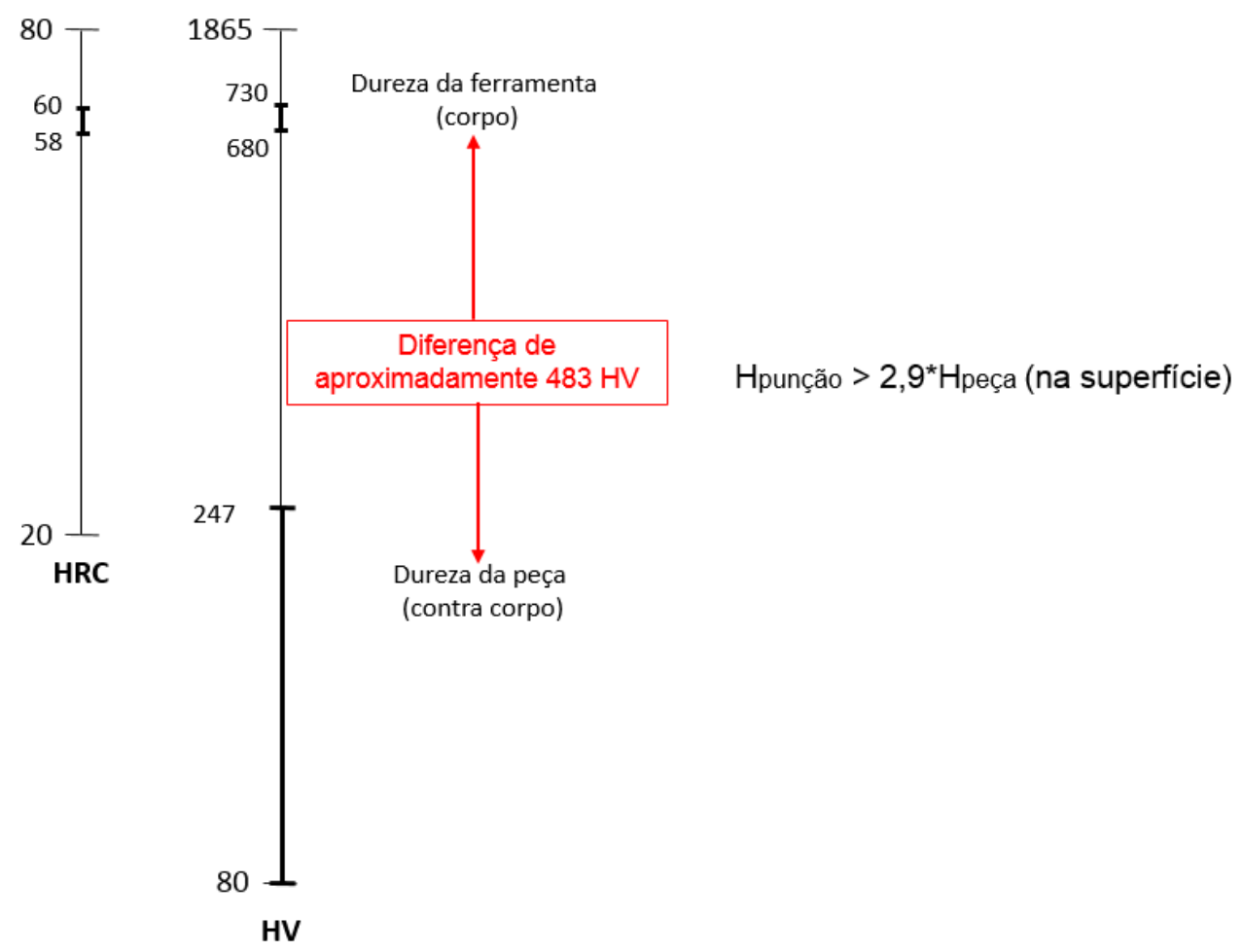

Figura 58 - Diferença de dureza entre corpo e contra-corpo

Ainda que a literatura sugira que o desgaste abrasivo seja governado por diferença de dureza entre corpo e contra-corpo, onde o corpo mais duro precisa ser 1,2 vezes mais duro que o corpo que sofre desgaste, os resultados apresentados nas seções a seguir não deixam dúvidas de que ocorre desgaste do corpo mais duro mesmo com a dureza da ferramenta sendo 2,9 vezes maior que a dureza do contracorpo.

\subsection{Perda de massa}

A Figura 59 apresenta a perda de massa dos punções após 52.000 ciclos, 102.000 ciclos e o total. As colunas vermelhas representam os punções "intermediários" com rugosidade $R_{a}$ entre 0,3 e 0,8 $\mu \mathrm{m}$, enquanto as colunas azuis representam os punções "polidos" com rugosidade $R_{a}$ entre 0,1 a $0,2 \mu \mathrm{m}$. Os punções "intermediários" 6, 7, 8 e 9 perderam respectivamente 0,05 g, 0,06 g, 0,05 g e 0,05 g após 102.000 ciclos, enquanto os punções "polidos" 11, 12, 13 e 15 perderam respectivamente $0,06 \mathrm{~g}, 0,05 \mathrm{~g}, 0,05 \mathrm{~g}$ e 0,05 g. Os resultados mostram que não houve diferença entre as ferramentas intermediárias e as polidas no que tange à perda de massa. 


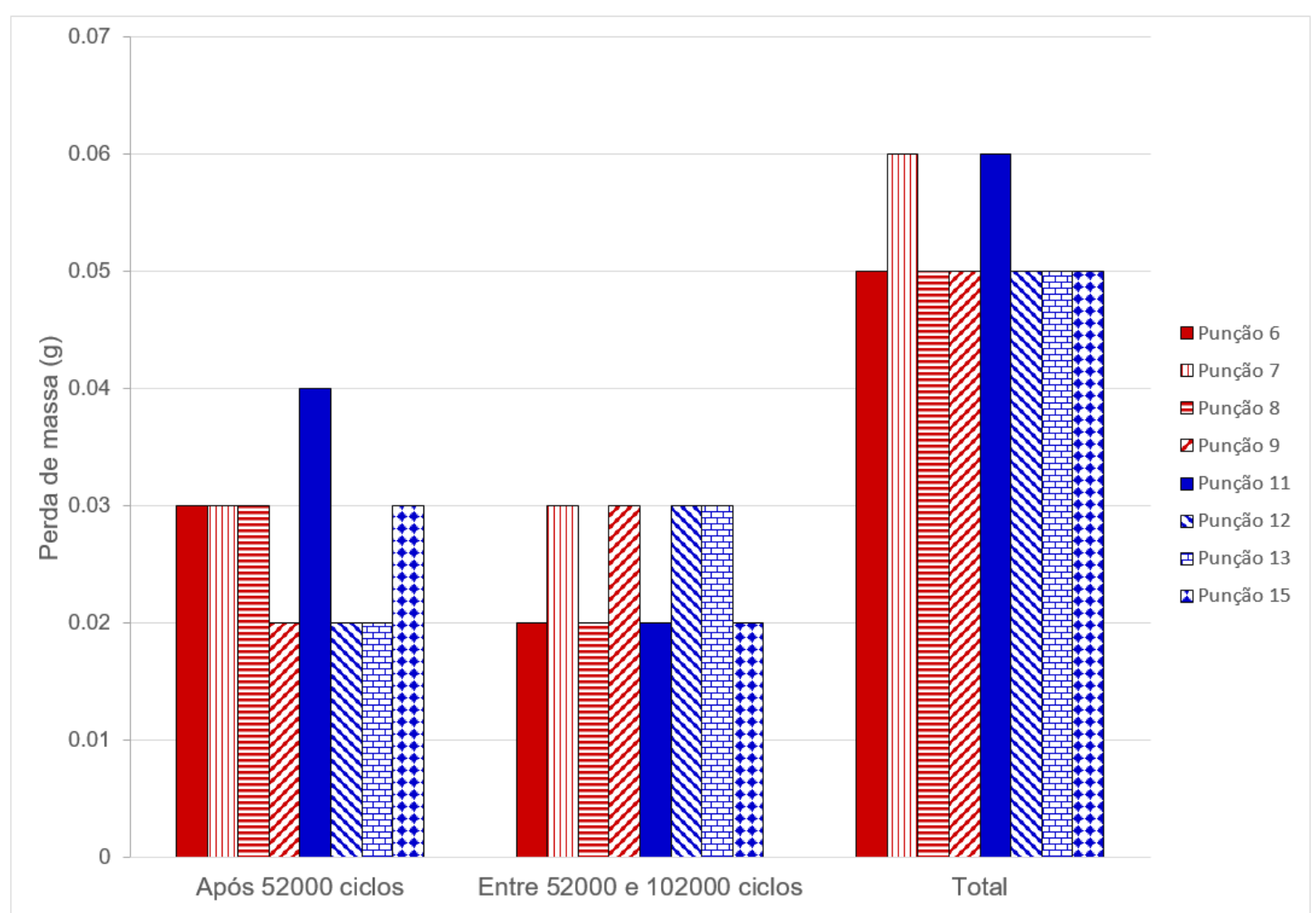

Figura 59 - Perda de massa dos punções

\subsection{Variação dimensional}

Entre todas as dimensões de projeto da ferramenta apresentadas na Figura 46 , a característica 4 , referente ao diâmetro de $7,25 \mathrm{~mm}$, é a mais crítica devido à sua importância para as operações subsequentes. Um diâmetro muito menor do que o especificado na segunda operação pode levar à flambagem do punção de terceira operação e, portanto, é uma característica que exige monitoramento ao decorrer da produção em série. A Figura 60 mostra a diminuição do diâmetro de $7,25 \mathrm{~mm}$, em valores absolutos, gerado pelo desgaste após 52.000 ciclos, entre 52.000 e 100.000 ciclos e o total. As colunas vermelhas representam os punções intermediários, enquanto as colunas azuis representam os punções polidos. 


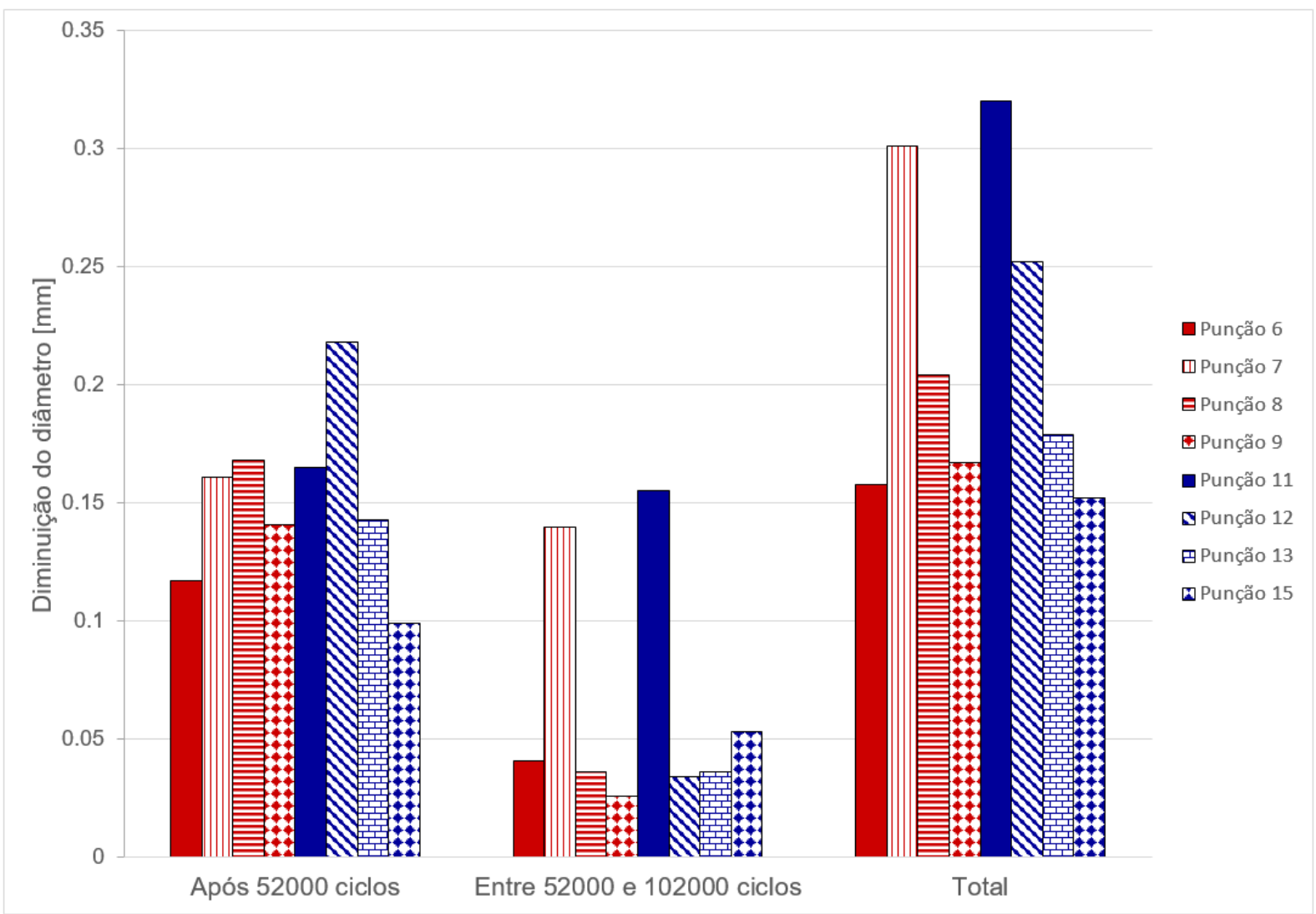

Figura 60 - Redução dimensional do diâmetro crítico

Observa-se que todos os punções reduziram-se nessa dimensão, sendo que a variação dimensional nos primeiros 52.000 ciclos é maior do que entre $52.000 \mathrm{e}$ 102.000 ciclos, o que sugere que o desgaste ocorra com maior intensidade nos primeiros ciclos de fabricação. Percebe-se também uma discrepância na redução dimensional dos punções 7 e 11 entre 52.000 e 102.000 ciclos, o que leva a crer que algo incomum ocorreu durante o lote de produção onde ambas as ferramentas foram utilizadas. Independente do motivo pelo qual ocorreu tal discrepância, não se observou um padrão que permitisse diferenciar as ferramentas intermediárias (punções 6, 7, 8 e 9) das polidas (punções 11, 12, 13 e 15).

\subsection{Rugosidade e topografia dos punções (corpo)}

As Figuras de 61 a 68 apresentam as topografias e as rugosidades para as ferramentas nas condições novas e usadas adquiridas em perfilômetro óptico 3D. As Figuras 61 e 62 mostram a superfície do topo do punção 2 antes de entrar em máquina pela primeira vez e após 52.000 ciclos de produção, respectivamente. Ambos os resultados não representam a superfície real da ferramenta de forma fidedigna, pois as franjas oriundas do processo de usinagem não foram identificadas 
devido à superfície opaca das ferramentas, independente do filtro utilizado no perfilômetro. Portanto, os valores de rugosidades dessa ferramenta não foram considerados como referência de comparação.
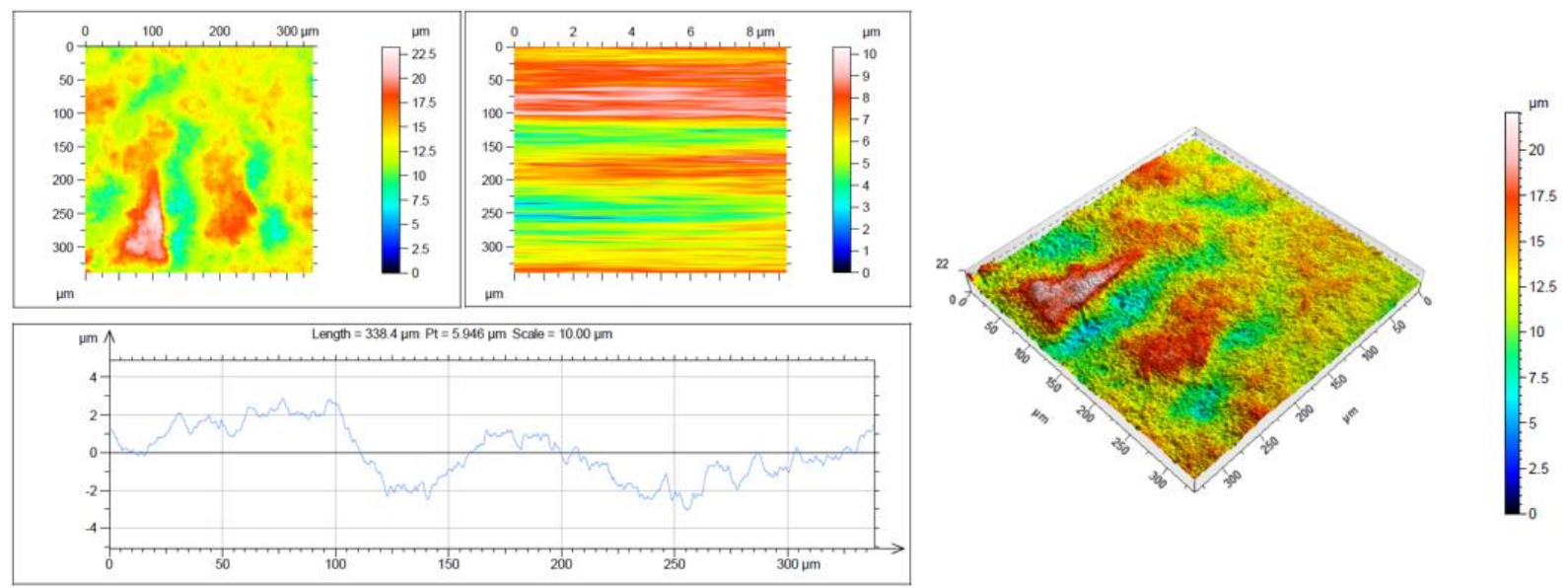

\begin{tabular}{|c|c|c|}
\hline \multicolumn{3}{|c|}{ ISO 25178} \\
\hline \multicolumn{3}{|c|}{ Height Parameters } \\
\hline $\mathrm{Sq}$ & 1.519 & $\mu \mathrm{m}$ \\
\hline Sa & 1.258 & $\mu \mathrm{m}$ \\
\hline Ssk & -0.1081 & \\
\hline Sku & 2.362 & \\
\hline Sp & 3.821 & $\mu \mathrm{m}$ \\
\hline Sv & 6.478 & $\mu \mathrm{m}$ \\
\hline Sz & 10.30 & $\mu \mathrm{m}$ \\
\hline
\end{tabular}

Figura 61 - Resultado incoerente de topografia do punção 2 (Rugoso) novo
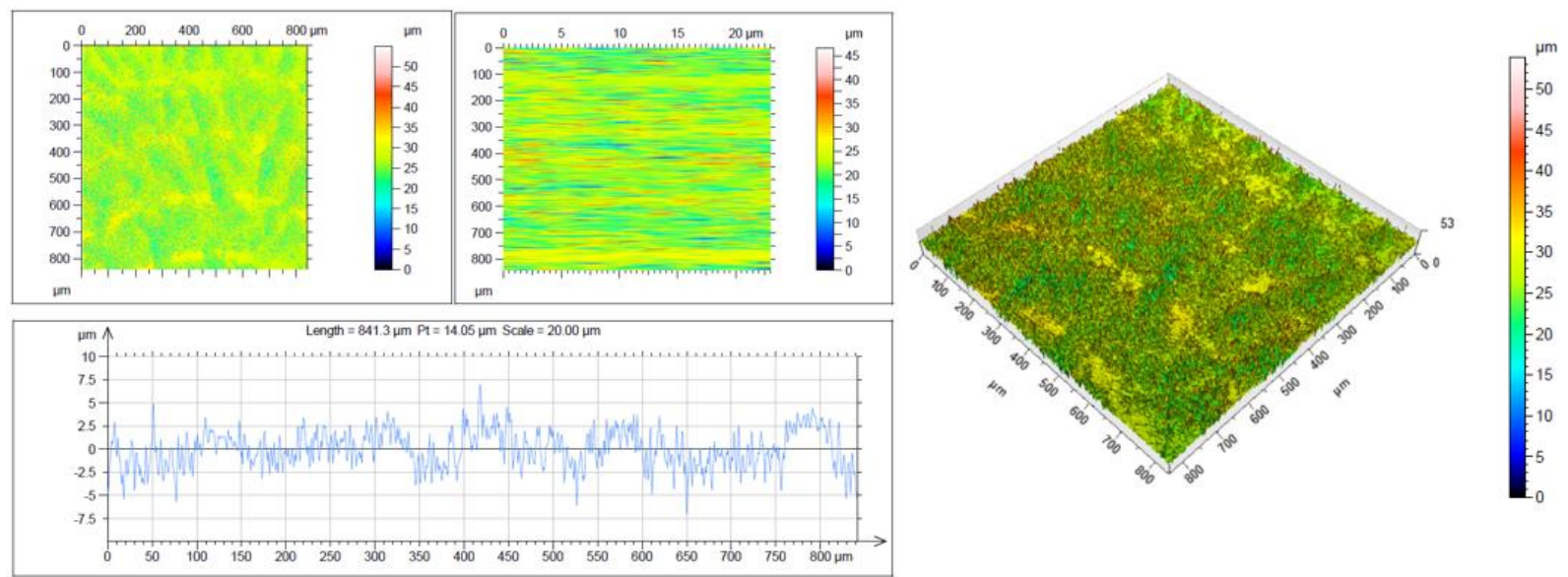

\begin{tabular}{|ccc|}
\hline \multicolumn{3}{|l|}{ ISO 25178 } \\
\multicolumn{3}{|l|}{ Height Parameters } \\
\hline Sq & 4.758 & $\mu \mathrm{m}$ \\
\hline Sa & 3.583 & $\mu \mathrm{m}$ \\
\hline Ssk & -0.1545 & \\
\hline Sku & 4.065 & \\
\hline Sp & 23.89 & $\mu \mathrm{m}$ \\
\hline Sv & 22.63 & $\mu \mathrm{m}$ \\
\hline Sz & 46.52 & $\mu \mathrm{m}$ \\
\hline
\end{tabular}

Figura 62 - Resultado incoerente de topografia do punção 2 (Rugoso) após 50.000 ciclos

As Figuras 63 e 64 apresentam respectivamente regiões do topo e da lateral do punção 7 antes de entrar em máquina pela primeira vez. Observam-se franjas de 
usinagem bem caracterizadas em função do processo de torneamento em ambas as regiões da ferramenta. As alturas dos picos variam de $0,5 \mu \mathrm{m}$ a $1,0 \mu \mathrm{m}$ e as profundidades dos vales variam entre $0,5 \mu \mathrm{m}$ e $1 \mu \mathrm{m}$. Uma vez que a superfície nova apresenta um padrão de picos e vales bem definidos, os valores de $R_{a}$ e $S_{a}$ são muito próximos. Os demais parâmetros não serão comentados aqui.

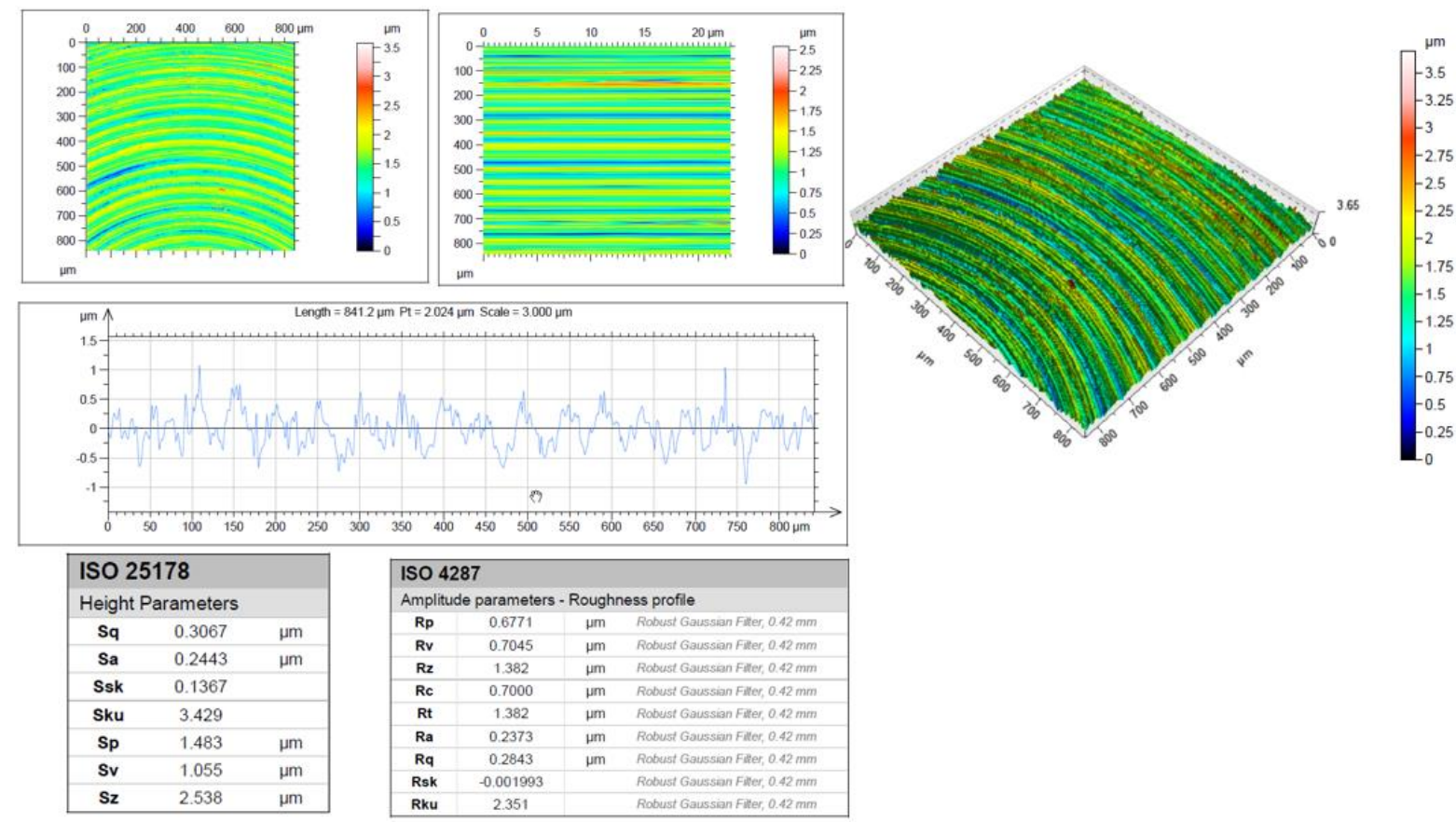

Figura 63 - Topografia e rugosidade do topo do punção 7 (Intermediário) novo
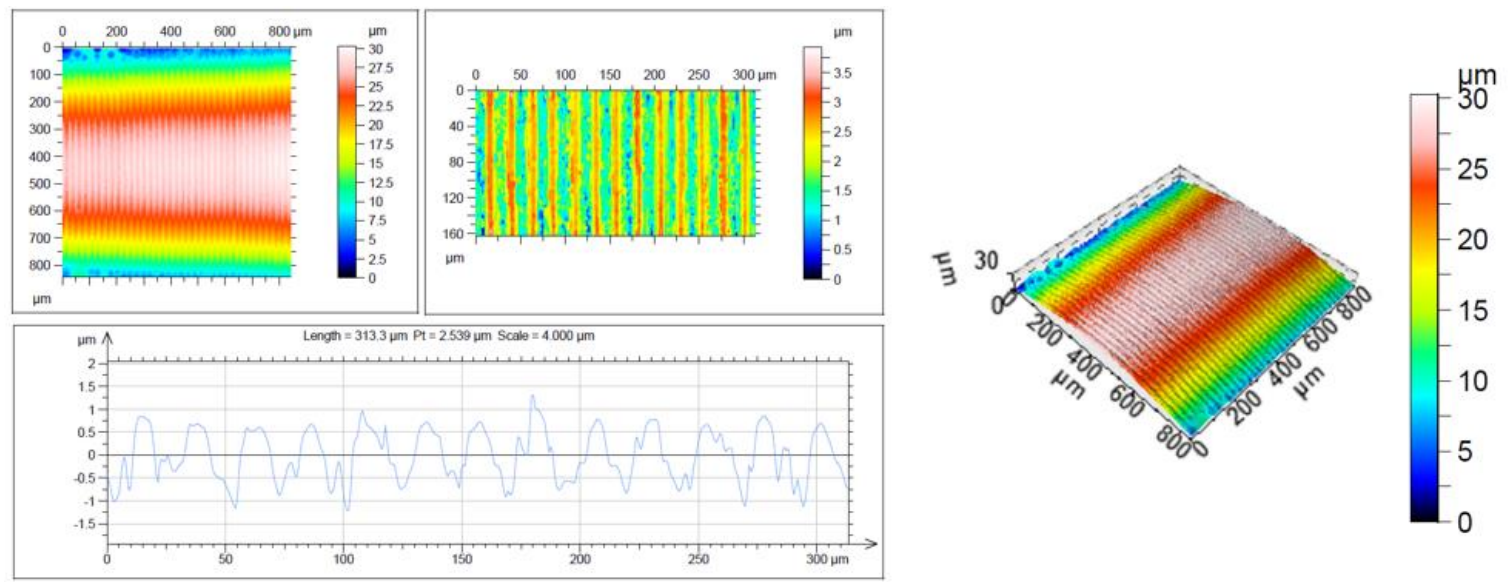

\begin{tabular}{|c|c|c|c|c|c|c|}
\hline \multicolumn{3}{|c|}{ ISO 25178} & \multicolumn{4}{|c|}{ ISO 4287} \\
\hline \multicolumn{3}{|c|}{ Height Parameters } & \multicolumn{4}{|c|}{ Amplitude parameters - Roughness profile } \\
\hline Sa & 05740 & um & Rp & 1.136 & $\mu \mathrm{m}$ & Gaussian filter, $0.08 \mathrm{~mm}$ \\
\hline & & $\mu \mathrm{m}$ & Rv & 1.064 & $\mu \mathrm{m}$ & Gaussian fitter, $0.08 \mathrm{~mm}$ \\
\hline Sa & 0.4906 & $\mu \mathrm{m}$ & $\mathbf{R z}$ & 2.200 & $\mu \mathrm{m}$ & Gaussian fitter, $0.08 \mathrm{~mm}$ \\
\hline Ssk & -0.004475 & & Rc & 1.690 & $\mu \mathrm{m}$ & Gaussian fitter, $0.08 \mathrm{~mm}$ \\
\hline Sku & 2.086 & & Rt & 2.472 & $\mu \mathrm{m}$ & Gaussian fitter, $0.08 \mathrm{~mm}$ \\
\hline $\mathrm{Sp}$ & 1.967 & $\mu \mathrm{m}$ & Ra & 0.4960 & $\mu \mathrm{m}$ & Gaussian fitter, $0.08 \mathrm{~mm}$ \\
\hline Sv & 1.947 & um & $\mathbf{R q}$ & 0.5609 & $\mu \mathrm{m}$ & Gaussian fitter, $0.08 \mathrm{~mm}$ \\
\hline$S 7$ & 3914 & & Rsk & -0.04884 & & Gaussian fitter, $0.08 \mathrm{~mm}$ \\
\hline Sz & 3.914 & $\mu \mathrm{m}$ & Rku & 1.861 & & Gaussian fitter, $0.08 \mathrm{~mm}$ \\
\hline
\end{tabular}

Figura 64 - Topografia e rugosidade da lateral do punção 7 (Intermediário) novo 
As Figuras 65 e 66 apresentam respectivamente regiões do topo e da lateral do punção 7 após 52.000 ciclos de conformação. No topo da ferramenta ainda é possível observar franjas de usinagem, o que caracteriza a continuidade da superfície com textura periódica. Dessa forma, os valores de $R_{a}$ e $S_{a}$ continuam muito próximos entre si, e também em comparação com a ferramenta nova. Por outro lado, a superfície da lateral da ferramenta foi completamente alterada pelo desgaste, gerando uma topografia com textura aleatória de difícil caracterização. Neste caso, os valores de $\mathrm{R}_{\mathrm{a}}$ e $\mathrm{S}_{\mathrm{a}}$ diferem significativamente.

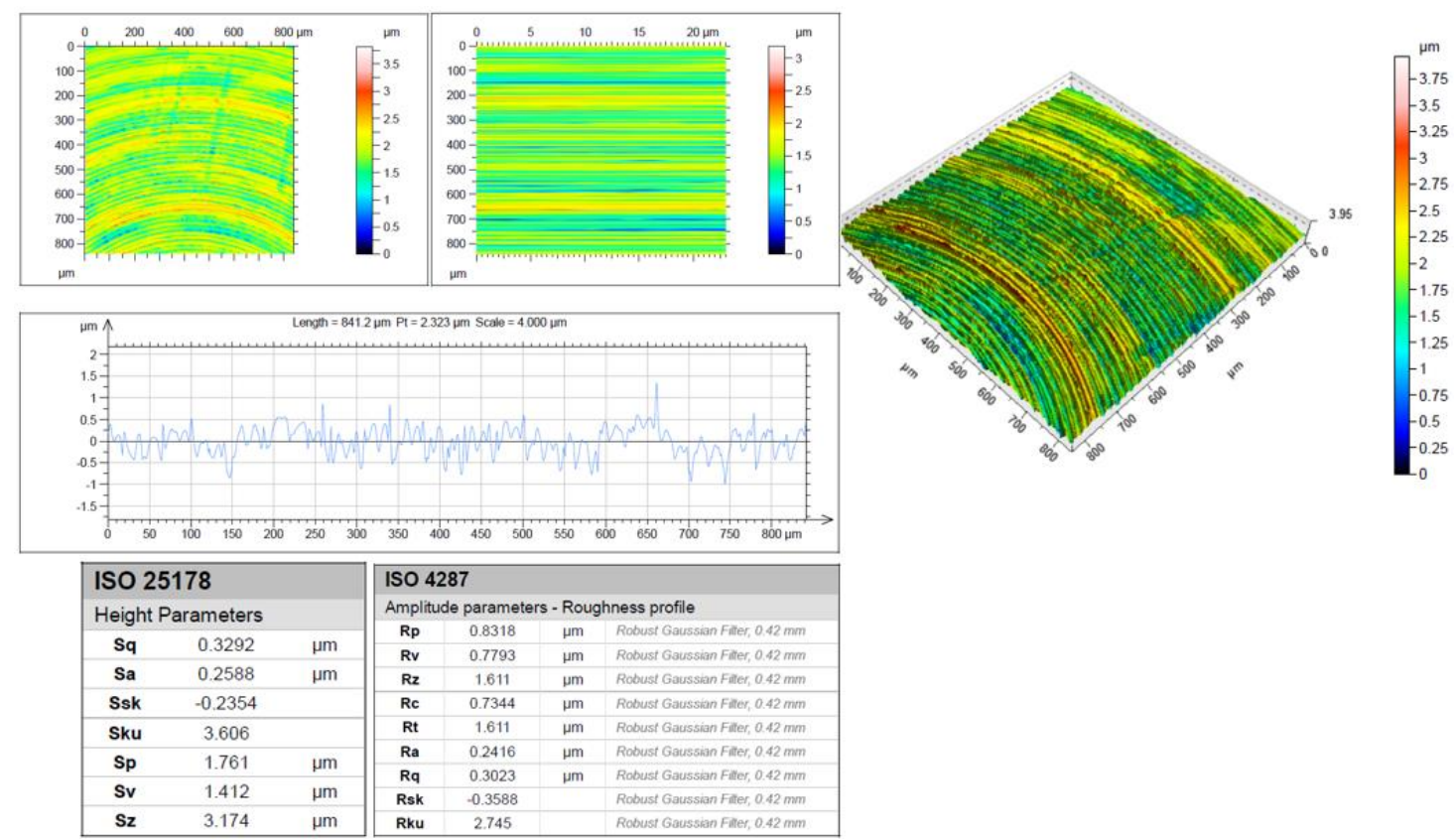

Figura 65 - Topografia e rugosidade do topo do punção 7 (Intermediário) após 50.000 ciclos
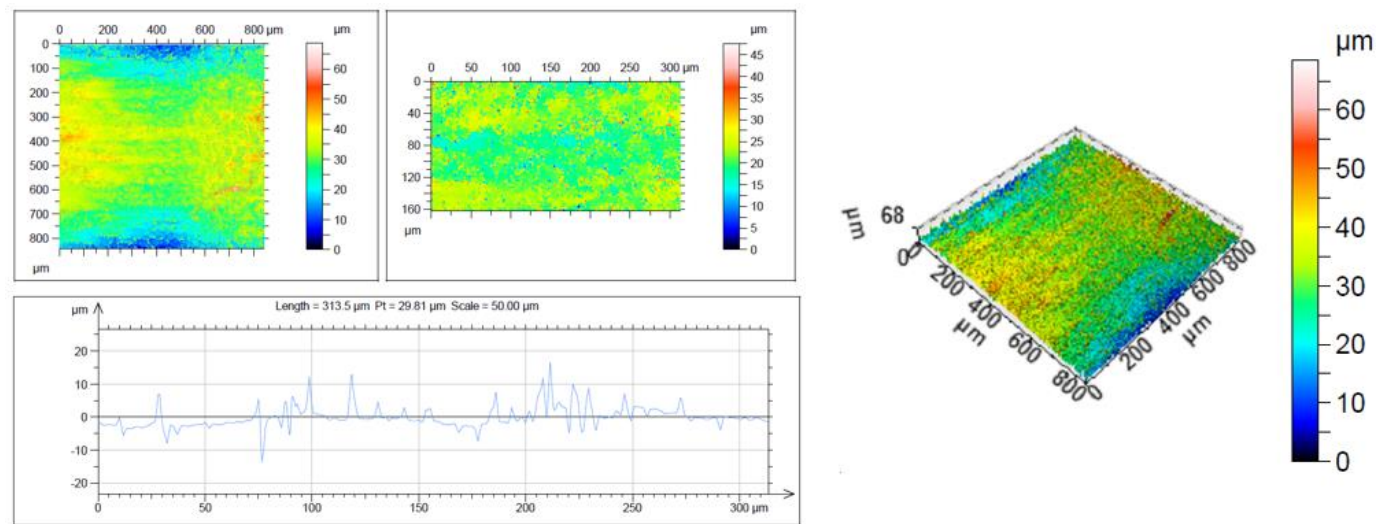

\begin{tabular}{|c|c|c|c|c|c|c|}
\hline \multicolumn{3}{|c|}{ ISO 25178} & \multicolumn{4}{|c|}{ ISO 4287} \\
\hline \multirow{2}{*}{\multicolumn{3}{|c|}{ Height Parameters }} & \multicolumn{4}{|c|}{ Amplitude parameters - Roughness profile } \\
\hline Sq & 3.470 & & Rp & 9.789 & $\mu \mathrm{m}$ & Gaussian filler, $0.08 \mathrm{~mm}$ \\
\hline & & & $\mathrm{Rv}$ & 9.383 & $\mu \mathrm{m}$ & Gaussian fititer, $0.08 \mathrm{~mm}$ \\
\hline & 2.455 & $\mu \mathrm{m}$ & Rz & 19.17 & $\mu \mathrm{m}$ & Gaussian filter, $0.08 \mathrm{~mm}$ \\
\hline Ssk & 0.5764 & & Rc & 10.16 & $\mu \mathrm{m}$ & Gaussian filiter, $0.08 \mathrm{~mm}$ \\
\hline Sku & 6.734 & & Rt & 26.56 & $\mu \mathrm{m}$ & Gaussian filter, $0.08 \mathrm{~mm}$ \\
\hline Sp & 28.01 & $\mu \mathrm{m}$ & $\mathbf{R a}$ & 1.580 & $\mu \mathrm{m}$ & Gaussian fiter, $0.08 \mathrm{~mm}$ \\
\hline Sv & 22.86 & $\mu \mathrm{m}$ & Rq & 2.428 & $\mu \mathrm{m}$ & Gaussian fitter, $0.08 \mathrm{~mm}$ \\
\hline Sz & 50.87 & (non & Rsk & 0.3770 & & Gaussian filter, $0.08 \mathrm{~mm}$ \\
\hline & & $\mu \mathrm{m}$ & Rku & 6.462 & & Gaussian fiter, $0.08 \mathrm{~mm}$ \\
\hline
\end{tabular}

Figura 66 - Topografia e rugosidade da lateral do punção 7 (Intermediário) após $\mathbf{5 0 . 0 0 0}$ ciclos 
A Figura 67 mostra a região do topo do punção 12 antes de entrar em máquina pela primeira vez. Assim como no caso do punção 7, apresentado na Figura 63, observam-se franjas de usinagem bem caracterizadas em função do processo de torneamento, porém, graças ao processo de polimento subsequente à usinagem, as alturas máximas dos picos foram reduzidas a no máximo $0,3 \mu \mathrm{m}$, e as profundidades máximas dos vales à 0,45 $\mu \mathrm{m}$.
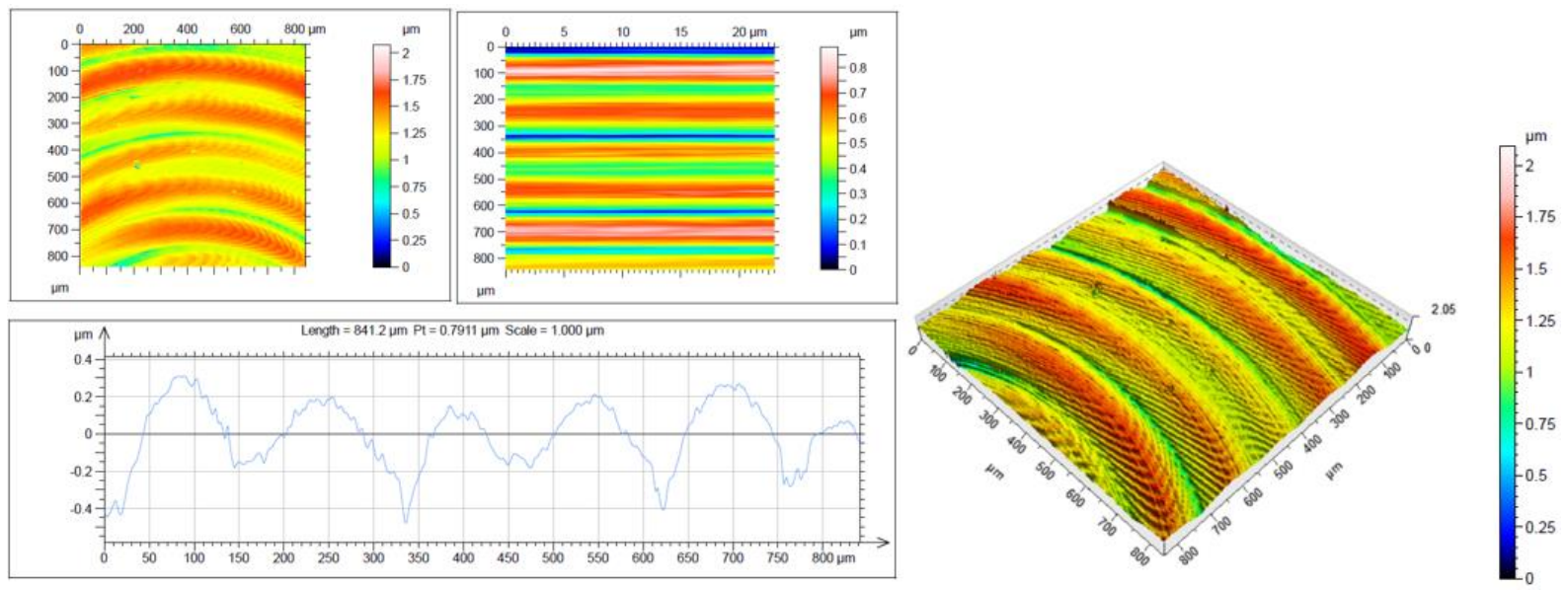

\begin{tabular}{|c|c|c|c|c|c|c|}
\hline \multicolumn{3}{|c|}{ ISO 25178} & \multicolumn{4}{|c|}{ ISO 4287} \\
\hline \multicolumn{3}{|c|}{ Height Parameters } & \multicolumn{4}{|c|}{ Amplitude parameters - Roughness profile } \\
\hline $\mathrm{Sq}$ & 0.1782 & $\mu \mathrm{m}$ & Rp & 0.2175 & $\mu \mathrm{m}$ & Robust Gaussian Filter, $0.42 \mathrm{~mm}$ \\
\hline Sa & 0.1472 & Im & $\mathbf{R v}$ & 0.4421 & $\mu \mathrm{m}$ & Robust Gaussian Fiter, $0.42 \mathrm{~mm}$ \\
\hline & & & Rz & 0.6596 & $\mu \mathrm{m}$ & Robust Gaussian Filter, $0.42 \mathrm{~mm}$ \\
\hline & -0.4471 & & Rc & 0.6439 & $\mu \mathrm{m}$ & Robust Gaussian Filter, $0.42 \mathrm{~mm}$ \\
\hline Sku & 2.616 & & Rt & 0.6596 & $\mu \mathrm{m}$ & Robust Gaussian Filter, $0.42 \mathrm{~mm}$ \\
\hline Sp & 0.3741 & $\mu \mathrm{m}$ & Ra & 0.1343 & $\mu \mathrm{m}$ & Robust Gaussian Filter, $0.42 \mathrm{~mm}$ \\
\hline Sv & 0.5060 & $\mu \mathrm{m}$ & $\mathbf{R q}$ & 0.1590 & $\mu \mathrm{m}$ & Robust Gaussian Filter, $0.42 \mathrm{~mm}$ \\
\hline Sz & 0.8801 & & Rsk & -0.7293 & & Robust Gaussian Filker, $0.42 \mathrm{~mm}$ \\
\hline & & $\mu \mathrm{m}$ & Rku & 2.811 & & Robust Gaussian Filter, $0.42 \mathrm{~mm}$ \\
\hline
\end{tabular}

Figura 67 - Topografia e rugosidade do topo do punção 12 (Polido) novo

A Figura 68 apresenta a topografia do topo do punção 12 após 52.000 ciclos de conformação. Ainda que seja possível identificar leves marcas de usinagem na superfície, observa-se que, devido ao processo de desgaste, os picos foram quase totalmente eliminados, resultando em uma altura máxima de 0,1 $\mu \mathrm{m}$. Essa análise indica que os picos do punção 12 foram "lixados" ou "amassados" durante o processo de conformação a frio, o que será comprovado por meio da análise superficial em microscópio eletrônico de varredura (MEV) apresentada na seção 5.5. 

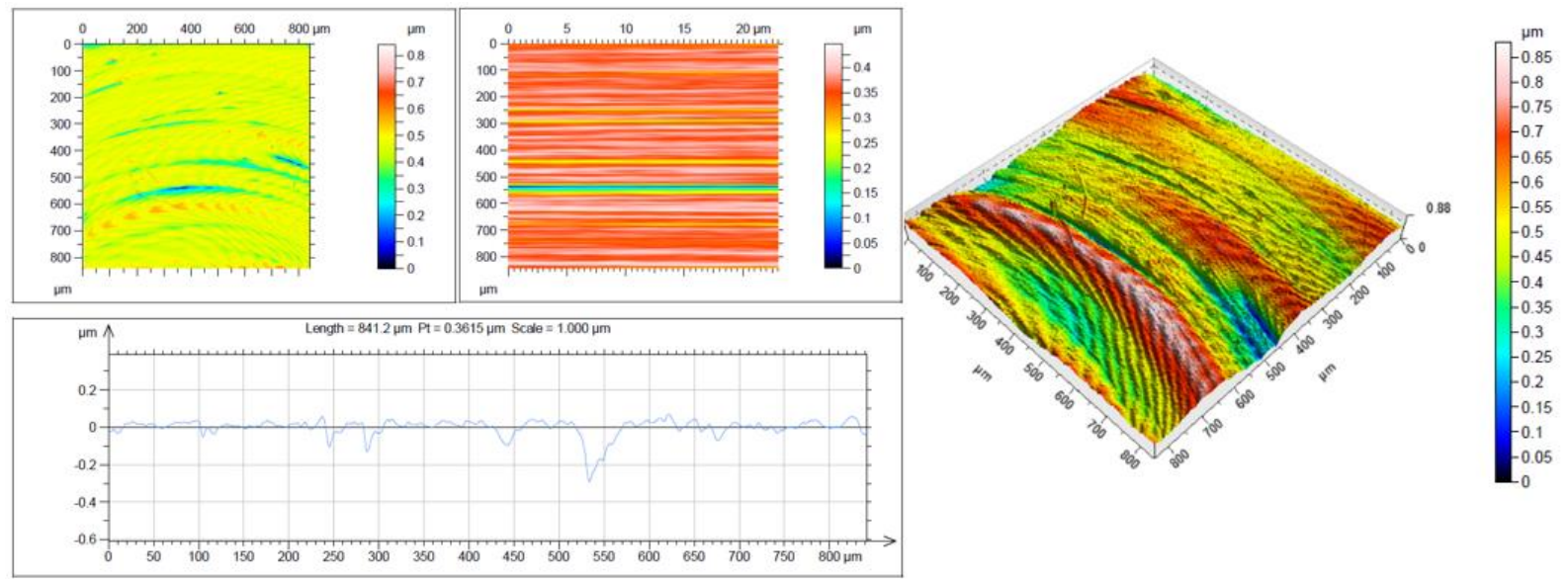

\begin{tabular}{|c|c|c|c|c|c|c|}
\hline \multicolumn{3}{|c|}{ ISO 25178} & \multicolumn{4}{|c|}{ ISO 4287} \\
\hline \multirow{2}{*}{\multicolumn{3}{|c|}{ Height Parameters }} & \multicolumn{4}{|c|}{ Amplitude parameters - Roughness profile } \\
\hline & & & Rp & 0.08055 & $\mu \mathrm{m}$ & Robust Gaussian Filter, $0.42 \mathrm{~mm}$ \\
\hline Sq & 0.04857 & $\mu \mathrm{m}$ & Rv & 0.2849 & $\mu \mathrm{m}$ & Robust Gaussian Filter, $0.42 \mathrm{~mm}$ \\
\hline Sa & 0.03047 & $\mu \mathrm{m}$ & Rz & 0.3655 & $\mu \mathrm{m}$ & Robust Gaussian Fitter, $0.42 \mathrm{~mm}$ \\
\hline Ssk & -2.759 & & Rc & 0.2220 & $\mu \mathrm{m}$ & Robust Gaussian Fitter, $0.42 \mathrm{~mm}$ \\
\hline Sku & 13.47 & & Rt & 0.3655 & $\mu \mathrm{m}$ & Robust Gaussian Fitter, $0.42 \mathrm{~mm}$ \\
\hline Sp & 0.09074 & $\mu \mathrm{m}$ & Ra & 0.04314 & $\mu \mathrm{m}$ & Robust Gaussian Fitter, $0.42 \mathrm{~mm}$ \\
\hline Sv & 0.3558 & um & Rq & 0.06253 & $\mu \mathrm{m}$ & Robust Gaussian Filiter, $0.42 \mathrm{~mm}$ \\
\hline Sz & 04055 & & Rsk & -2.259 & & Robust Gaussian Fitter, $0.42 \mathrm{~mm}$ \\
\hline & 0.4465 & $\mu \mathrm{m}$ & Rku & 8.432 & & Robust Gaussian Filter, $0.42 \mathrm{~mm}$ \\
\hline
\end{tabular}

Figura 68 - Topografia e rugosidade do topo do punção 12 (Polido) após 50.000 ciclos

As análises de rugosidade revelaram que para as ferramentas novas, as quais apresentam um padrão de topografia bem definido devido à presença das franjas de usinagem, os valores de $R_{a}$ e $S_{a}$ são equivalentes. A partir do momento que a topografia assume um carácter aleatório devido ao desgaste, a medição de rugosidade por meio de rugosímetro de agulha se torna incoerente, uma vez que o mesmo punção apresentaria valores de rugosidades $R_{a}$ e $S_{a}$ substancialmente diferentes em função da seção medida. Além disso, o progresso do desgaste no topo do punção ocorre de maneira diferente da lateral. Enquanto o topo ainda apresenta características da topografia inicial torneada após 52.000 ciclos, a lateral foi totalmente descaracterizada, o que indica que a severidade do desgaste é maior na lateral.

\subsection{Dano superficial}

Os resultados apresentados nas seções, 5.2, 5.3 e 5.4 indicam que houve alteração de massa, de geometria e de topografia das ferramentas devido à ocorrência de desgaste após 52.000 ciclos de conformação. Nesta seção, apresenta-se a análise comparativa do comportamento das superfícies das ferramentas novas e usadas, realizada em MEV, a fim de identificar os tipos de 
danos superficiais e os modos de desgaste atuantes. A Figura 69 apresenta a topografia do punção 2 novo, com aumentos progressivos entre 20 a 500 vezes. Percebe-se nas imagens (a) e (b) a presença de franjas de usinagem bem definidas, provenientes do processo de torneamento, resultando em uma superfície com textura periódica tanto no topo quanto na lateral da ferramenta. As imagens (c), (d), (e) e (f), referentes a aumentos progressivos na lateral da ferramenta, não foram bem caracterizadas provavelmente devido ao acabamento superficial ruim da ferramenta. Análises de EDS descartaram a presença de óxido ou resíduo de óleo nessas áreas.

A Figura 70 apresenta a topografia do punção 2 após 52.000 ciclos de conformação. Percebe-se nas imagens (a) e (b) que o topo da ferramenta ainda contém as franjas de usinagem, porém, nota-se que os picos foram arredondados e eles aparentam estar mais baixos do que na ferramenta nova. Tanto o topo quanto a lateral da ferramenta apresentam riscos e sulcos perpendiculares às franjas de usinagem e no sentido de escoamento do contra-corpo, caracterizando o desgaste abrasivo. Na imagem (b), nota-se que o desgaste ocorreu com intensidade diferente no topo e na lateral da ferramenta, sendo que o topo ainda manteve alguma característica da topografia inicial, enquanto a lateral foi totalmente descaracterizada pelo desgaste abrasivo. Ainda na Figura 70, percebe-se nas imagens (c) e (d) partículas aderidas à superfície da ferramenta, indicadas com as setas vermelhas, com um tamanho próximo à largura dos riscos, o que pode indicar que partículas similares a estas tenham atuado como debris entre a ferramenta e a peça durante 0 processo de conformação a frio. A imagem (e) apresenta a análise em elétrons retroespalhados, a qual evidencia que essas partículas apresentam composição química diferente da matriz da ferramenta. Uma outra possível origem para os debris é o desplacamento da matriz da ferramenta conforme ilustrado na imagem (f). Ainda nesta imagem, percebe-se micro trincas radiais iniciadas por atrito e propagadas por fadiga devido ao contato cíclico entre a ferramenta e a peça. 

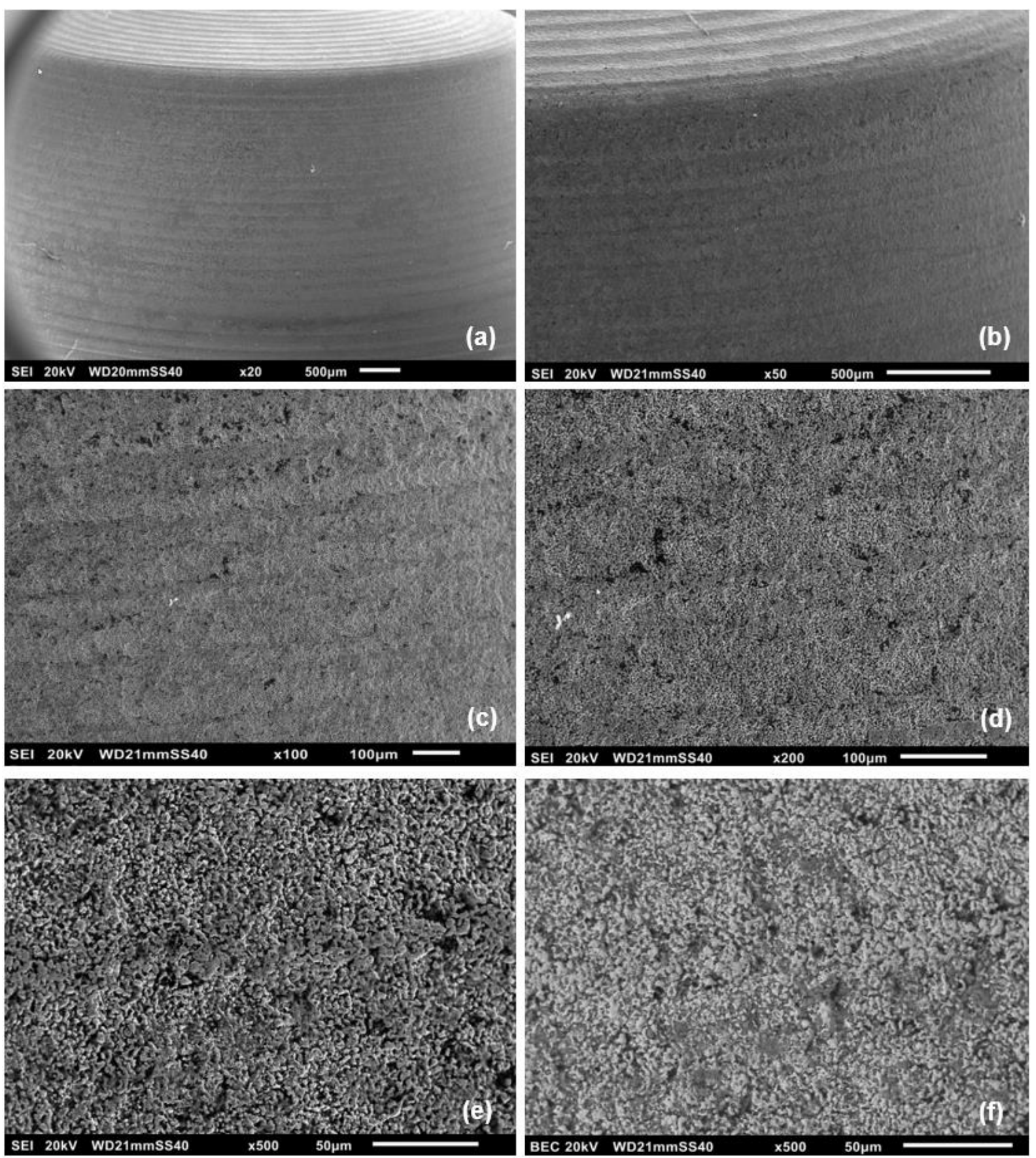

Figura 69 - Punção 2 (Rugoso) novo; (a) imagem de elétron secundário com aumento de 20 vezes, (b) 50 vezes, (c) 100 vezes, (d) 200 vezes, (e) 500 vezes e (f) imagem de elétron retroespalhado com aumento de 500 vezes 

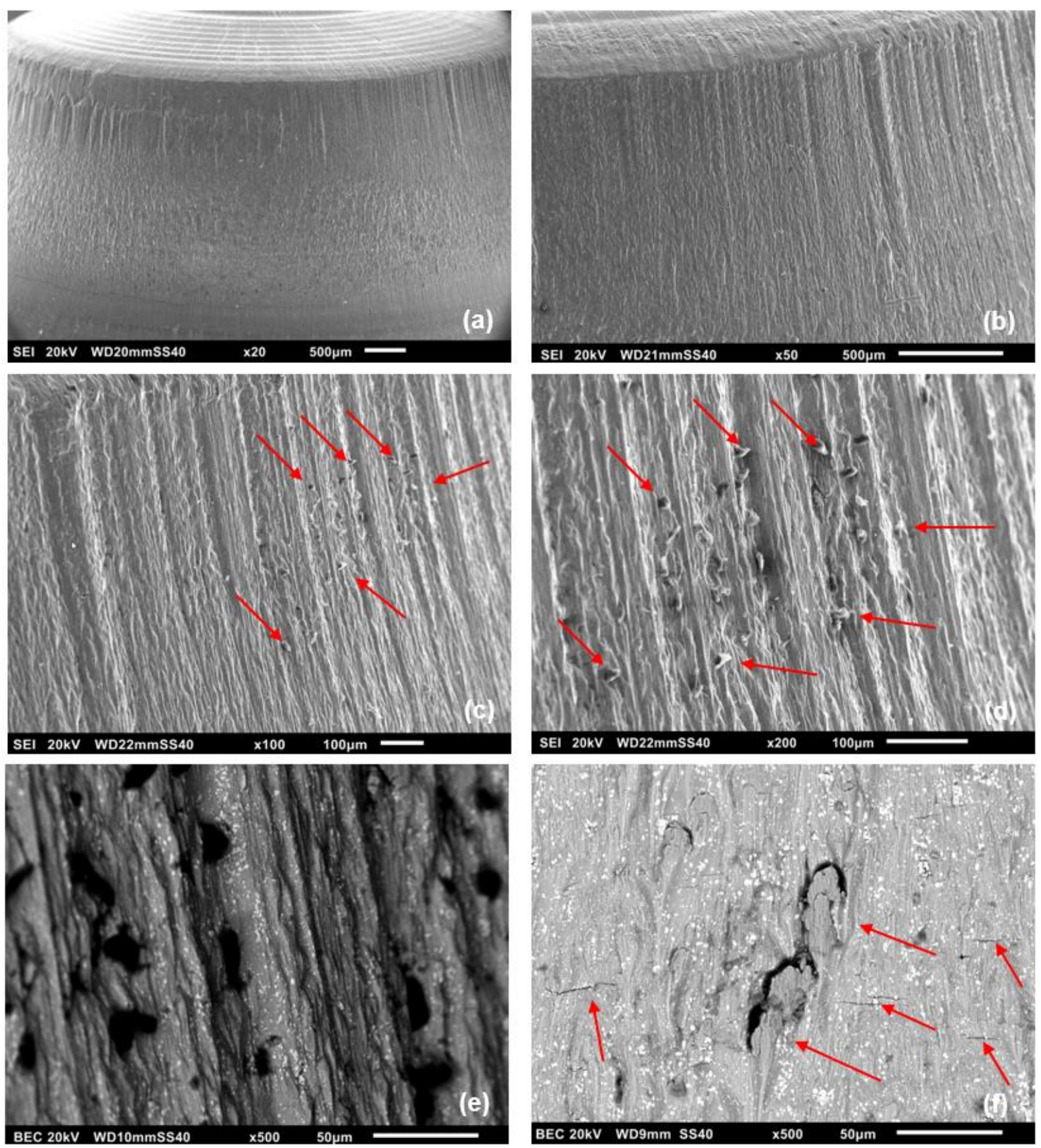

Figura 70 - Punção 2 (Rugoso) após 52.000 ciclos; (a) imagem de elétron secundário com aumento de 20 vezes, (b) 50 vezes, (c) 100 vezes, (d) 200 vezes, (e) imagem de elétron retroespalhado com aumento de 500 vezes, (f) idem (e)

A Figura 71 apresenta a topografia do punção 7 novo, com os mesmos aumentos progressivos entre 20 e 500 vezes. Observa-se a textura periódica, proveniente do processo de usinagem, em todas as imagens. 


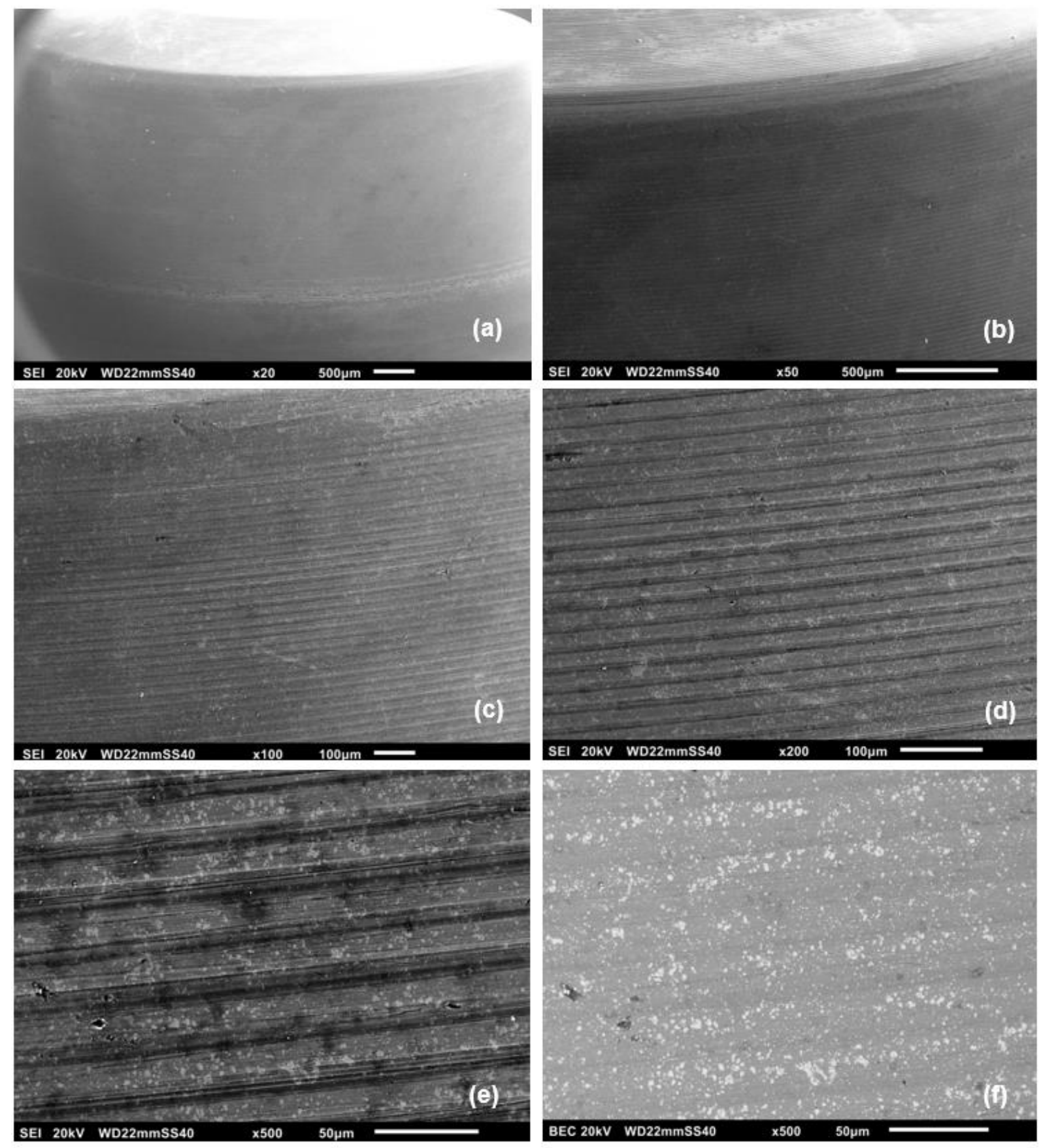

Figura 71 - Punção 7 (Intermediário) novo; (a) imagem de elétron secundário com aumento de 20 vezes, (b) 50 vezes, (c) 100 vezes, (d) 200 vezes, (e) 500 vezes e (f) imagem de elétron retroespalhado com aumento de 500 vezes

A imagem de elétron retroespalhados (f) evidencia a presença de carbonetos dispersos na matriz com tamanhos entre $1 \mu \mathrm{m}$ e $10 \mu \mathrm{m}$.

A Figura 72 apresenta a topografia do punção 7 após 52.000 ciclos de conformação. Observa-se nas imagens (a) e (b) que o topo da ferramenta ainda apresenta características da topografia inicial usinada, porém com riscos perpendiculares às franjas de usinagem. 


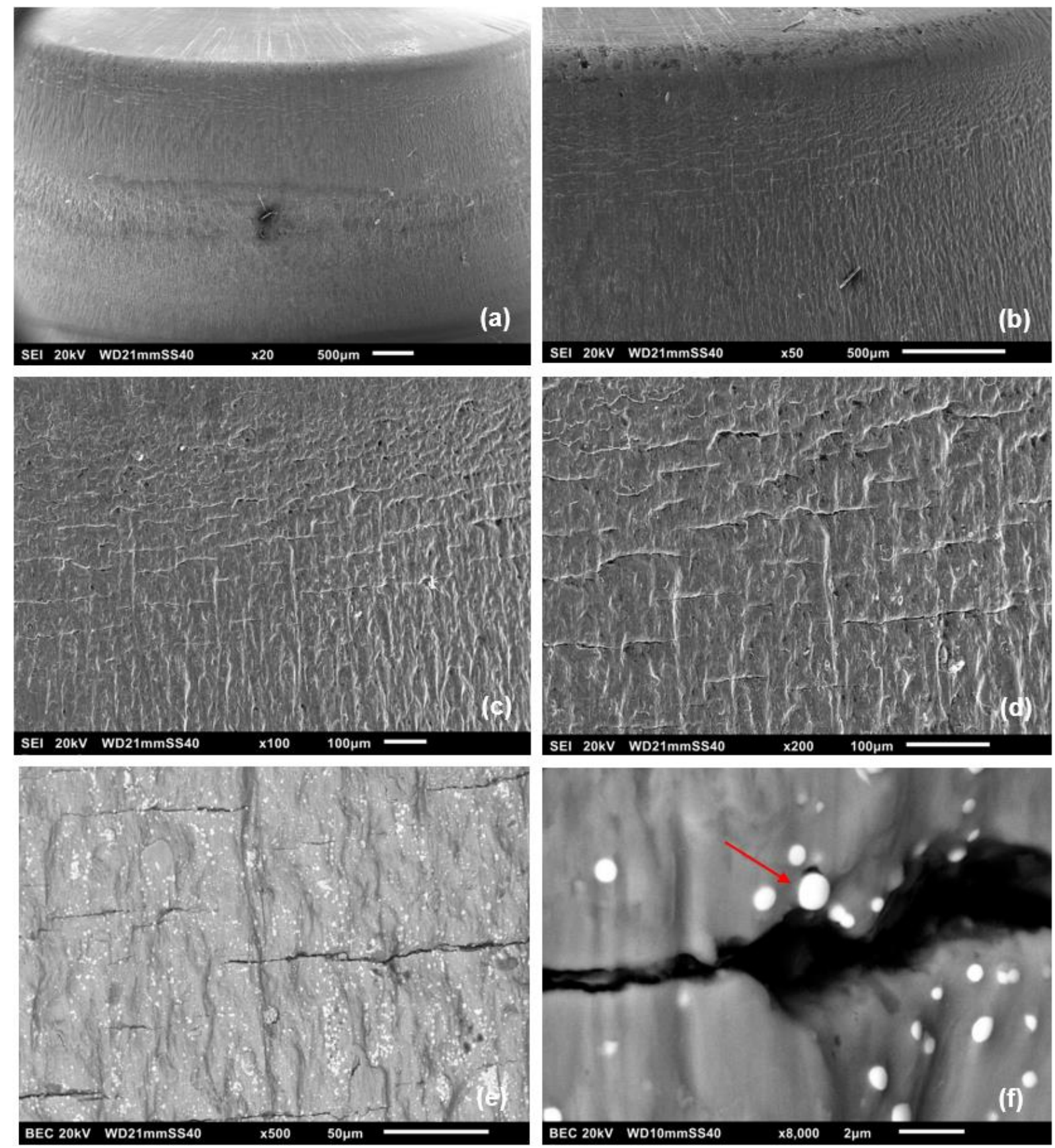

Figura 72 - Punção 7 (Intermediário) após 52.000 ciclos; (a) imagem de elétron secundário com aumento de 20 vezes, (b) 50 vezes, (c) 100 vezes, (d) 200 vezes, (e) imagem de elétron retroespalhado com aumento de 500 vezes, (f) idem (e) com aumento de 8000 vezes

As imagens (c), (d) e (e) mostram que as marcas de usinagem na lateral da ferramenta deram lugar a riscos e sulcos no sentido de escoamento da peça. Além disso, observa-se uma alta concentração de micro trincas nessa região causadas pelo contato cíclico entre a ferramenta e a peça. A imagem (f) destaca um carboneto que aparenta estar na iminência de se desprender do substrato. Uma vez liberado, o carboneto pode atuar como partícula abrasiva para o tribossistema.

A Figura 73 apresenta a topografia do punção 12 novo. 


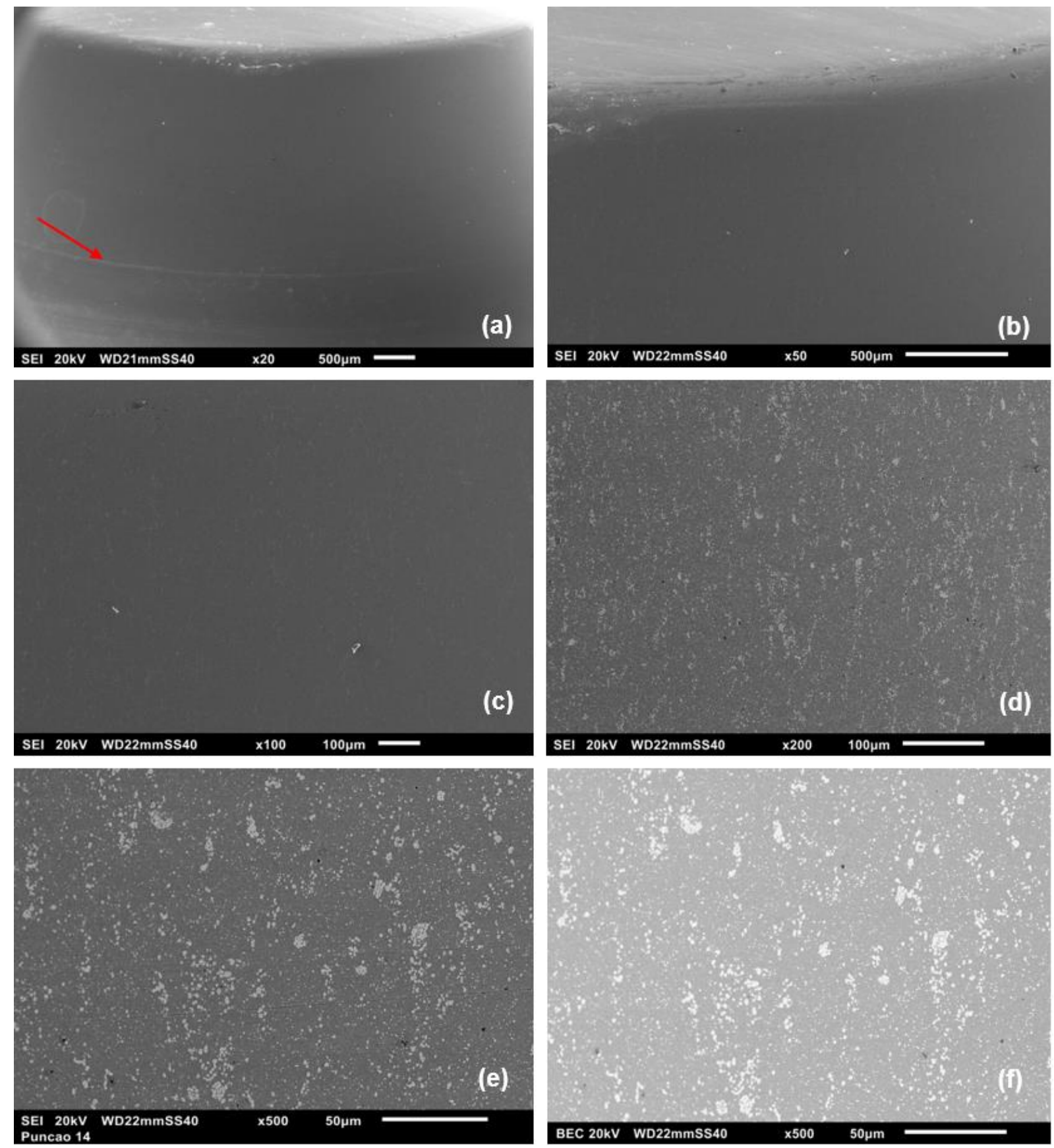

Figura 73 - Punção 12 (Polido) novo; (a) imagem de elétron secundário com aumento de 20 vezes, (b) 50 vezes, (c) 100 vezes, (d) 200 vezes, (e) 500 vezes e (f) imagem de elétron retroespalhado com aumento de 500 vezes

Devido ao processo de polimento, a ferramenta apresenta a superfície lisa ao longo de toda sua extensão, não sendo possível identificar as marcas do torneamento. A exceção é uma única marca de usinagem, mostrada na imagem 73(a), que não foi removida durante o processo de polimento.

A Figura 74 apresenta a topografia do punção 12 após 52.000 ciclos de conformação. As imagens (a) e (b) mostram riscos no topo da ferramenta e severa deformação plástica na lateral. 

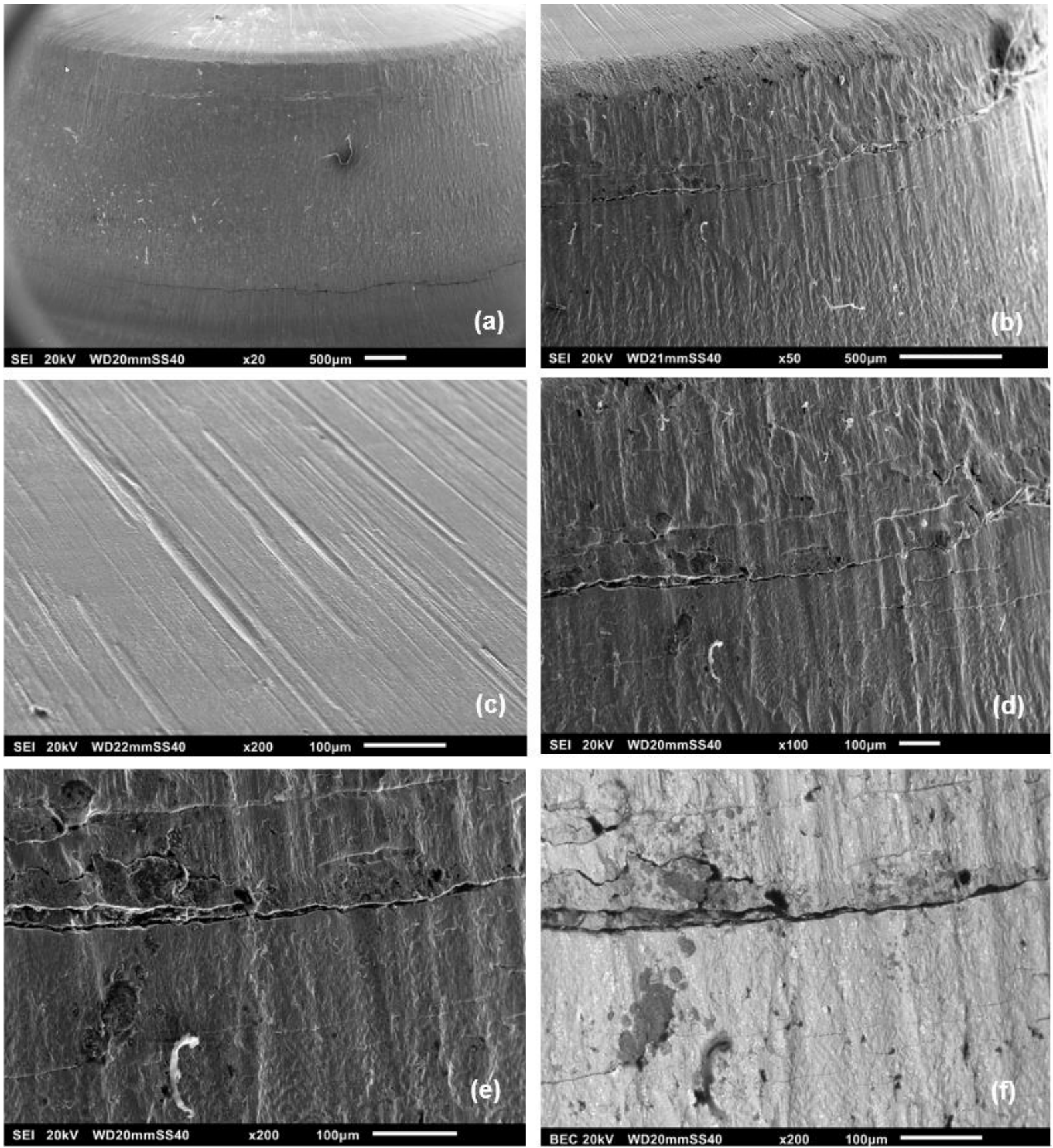

Figura 74 - Punção 12 (Polido) após 52.000 ciclos; (a) imagem de elétron secundário com aumento de 20 vezes, (b) 50 vezes, (c) 200 vezes, (d) 100 vezes, (e) 200 vezes e (f) imagem de elétron retroespalhado com aumento de 200 vezes

A imagem (c) apresenta uma parte do topo da ferramenta que destaca a presença de riscos na superfície. A forma dos canais indica, aparentemente, que os riscos foram causados por corpos de forma arredondada. Com exceção da imagem (c), todas as outras imagens da Figura 74 mostram a presença de micro trincas na lateral da ferramenta. A imagem (f) mostra um possível contaminante aderido à superfície da ferramenta. Análises de EDS não mostraram presença de elementos de liga típicos de aço ferramenta como vanádio, tungstênio, cromo ou molibdênio no contaminante. 
Em síntese, as análises de dano superficial das ferramentas após 52.000 ciclos de conformação indicam que:

a) O punção 2 rugoso (Figura 70d) aparenta ter os riscos mais profundos na lateral em comparação aos punções 7 intermediário (Figura 72d) e 12 polido (Figura 74e).

b) Entre as regiões analisadas, foram encontradas partículas aderidas somente na lateral do punção 2 rugoso (Figuras $70 \mathrm{~d}$ e $70 \mathrm{e}$ ).

c) O sentido das micro trincas encontradas nas laterais de todos os punções é perpendicular ao sentido de escoamento do material e coincide com o sentido das marcas de usinagem (Figuras 70a, 72a-e, 74a-f).

d) O punção 7 intermediário aparenta ter uma densidade de micro trincas superior aos dos outros punções (Figuras 70c, 72c e 74d).

e) O punção 12 polido aparenta ter as micro trincas de maior comprimento (Figuras $74 \mathrm{e}, \mathrm{f}$ ).

f) O desgaste no topo das ferramentas aparenta ser similar para os punções 7 intermediário e 12 polido e mais severo para o punção 2 rugoso (Figuras 70b, 72b e 74b).

Comparando as imagens 70b, 72a e 74a percebe-se que a forma com que 0 topo dos punções 2, 7 e 12 se desgastaram se assemelha muito com o desgaste do punção apresentado por Falconnet (2015) na Figura 25, sendo que os cortes evidenciados nos punções indicam desgaste abrasivo. No entanto, não é possível observar micro trincas no punção apresentado por Falconnet. Não se sabe se o autor não usou aumento suficiente para que as trincas fossem evidenciadas, ou se elas são de fato ausentes.

A presença de trincas perpendiculares ao sentido de deslizamento do material, pode ser explicada tanto por tensões trativas geradas por atrito durante 0 sulcamento, como também por fadiga de superfície de forma análoga à apresentada nas Figuras 29 e 32 . O efeito da rugosidade na densidade e comprimento das 
trincas foi investigado analisando a seção transversal dos punções e será apresentado na seção 5.6. Essa investigação foi realizada para analisar se os punções com rugosidade inicial $R_{a}$ entre 1,5 e 2,5 $\mu \mathrm{m}$, os quais falharam prematuramente, podem apresentar trincas maiores do que os demais punções, o que levaria a concluir que rugosidades maiores geram uma força de atrito maior e, consequentemente, tensões trativas maiores que aceleraram a velocidade de nucleação das trincas.

\subsection{Análise da seção transversal dos punções}

A Figura 75 apresenta um comparativo das maiores trincas encontradas nas seções transversais dos punções 1 (rugoso), 7 (intermediário) e 12 (polido). Nesse comparativo, o punção 1 foi analisado após 52.000 ciclos (momento em que a fratura ocorreu), enquanto os punções 7 e 12 foram analisados após 102.000 ciclos de produção. Percebe-se que além da fratura que determinou o fim da vida útil do punção 1, foi encontrada uma trinca com profundidade de $2650 \mu \mathrm{m}$, o que contrasta com os resultados de $277 \mu \mathrm{m}$ e $350 \mu \mathrm{m}$ encontrados nas seções dos punções 7 e 12, respectivamente. Considerando o número de ciclos que cada ferramenta trabalhou, e o fato de que todos os punções apresentam microestruturas equivalentes e, consequentemente, a mesma velocidade de propagação de trinca, conclui-se que as trincas nuclearam aproximadamente 18 vezes mais rápido no punção mais rugoso do que nos punções intermediários e nos polidos. Essa análise comprova que a rugosidade inicial dos corpos em contato desempenha um papel essencial na durabilidade das ferramentas, sendo que para o tribossistema analisado, uma rugosidade $R_{a}$ inicial entre 1,5 e 2,5 $\mu \mathrm{m}$ acelerou substancialmente 0 processo de nucleação de trinca devido à forças de atrito maiores do que a gerada pelos punções intermediários ou polidos. Considerando todas as variáveis que podem afetar o desgaste de uma ferramenta de conformação a frio operando em regime de produção seriada, os comprimentos das trincas dos punções 7 e 12 podem ser considerados equivalentes após 102.000 ciclos de fabricação e, portanto, o polimento efetuado na superfície do punção 12 não apresentou vantagem em termos de durabilidade. 


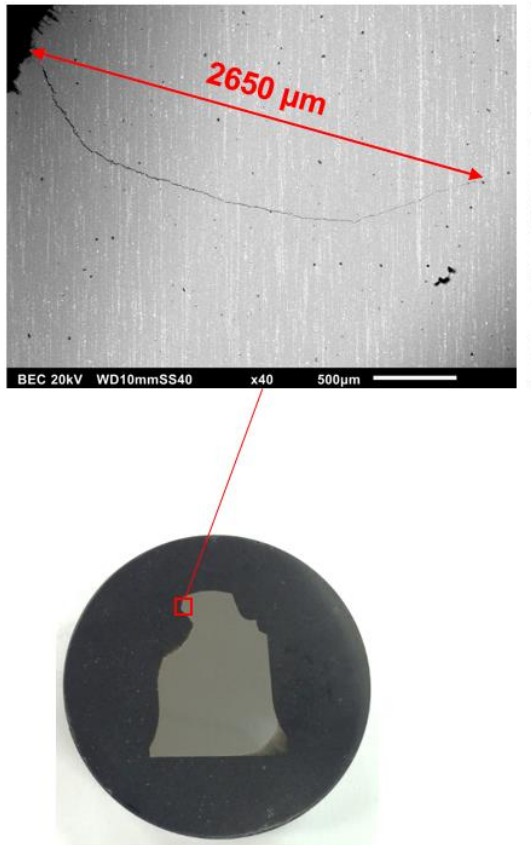

Punção 1 (Rugoso)
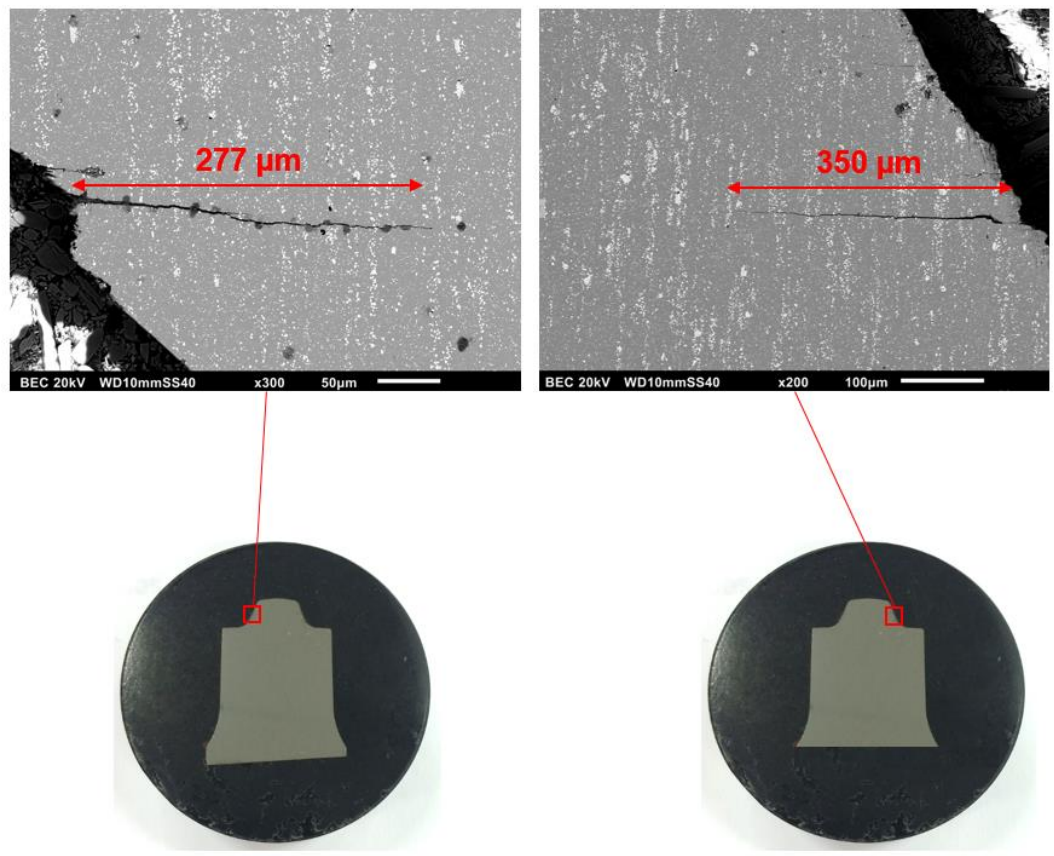

Punção 7 (Intermediário)

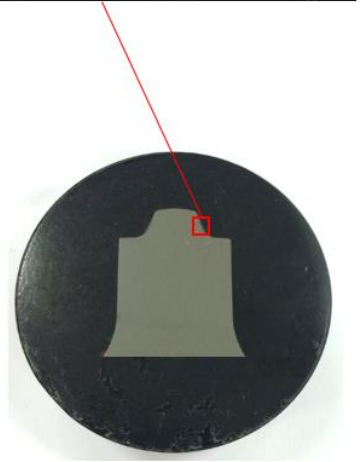

Punção 12 (Polido)

Figura 75 - Comparativo entre as maiores trincas encontradas nas seções transversais dos punções

Após a análise comparativa dos comprimentos das trincas dos punções, analisou-se a distribuição dos elementos químicos nas seções transversais por meio de raio $x$. Essa análise foi inicialmente realizada para verificar se existia alguma camada espessa de óxido, ou de outro material, aderido na superfície da ferramenta.

A Figura 76 apresenta o mapeamento, realizado em MEV, da distribuição de elementos químicos por raio $x$ da seção transversal do punção 1. As imagens mostram os elementos $\mathrm{Si}, \mathrm{Cr}$ e $\mathrm{Mn}$ distribuídos de forma homogênea por toda ferramenta, enquanto os elementos Mo, V e W, além de presentes em toda área da ferramenta, se concentram principalmente nos carbonetos. Em contraste, o Fe se encontra apenas nas áreas onde não há carbonetos. Nenhuma camada aderida na superfície da seção analisada foi encontrada, porém essa imagem servirá como base comparativa para verificar se existem partículas do contra-corpo aderidas na superfície das ferramentas. 

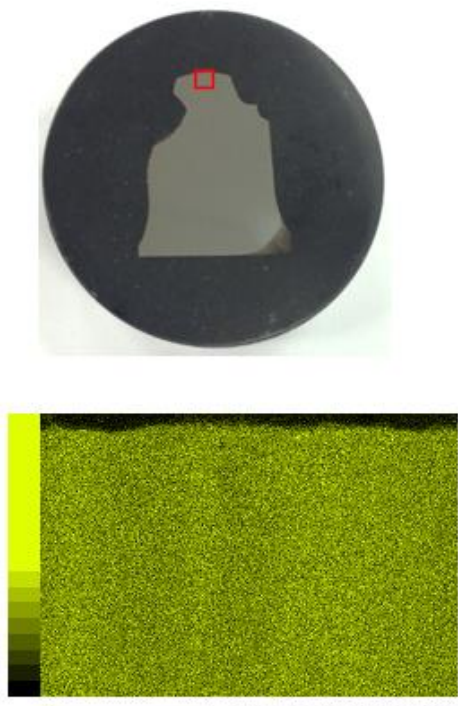

$100 \mu \mathrm{mCr} \mathrm{K}$

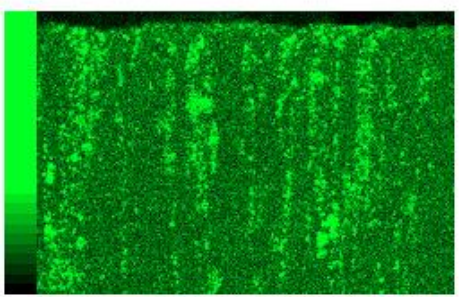

$30 \mu \mathrm{m}$

Mo L

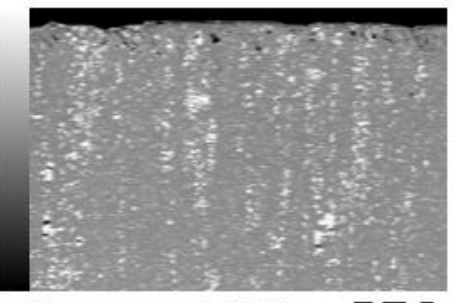

$100 \mu \mathrm{mBEC}$

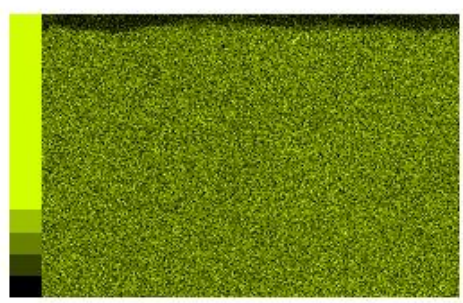

$30 \mu \mathrm{m}$

Mn K

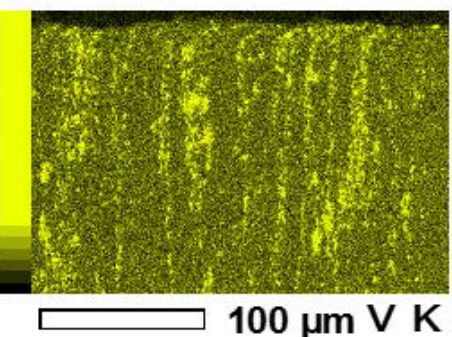

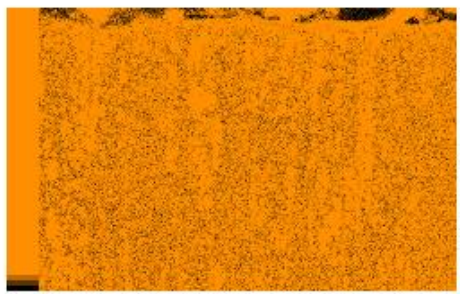

$100 \mu \mathrm{mSi} K$

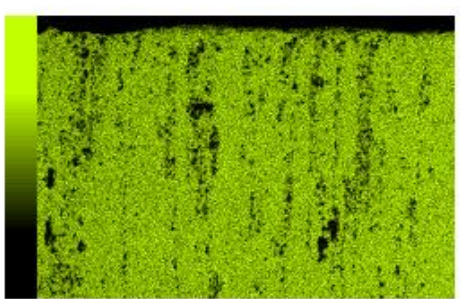

$\square 30 \mu \mathrm{m}$

Fe K

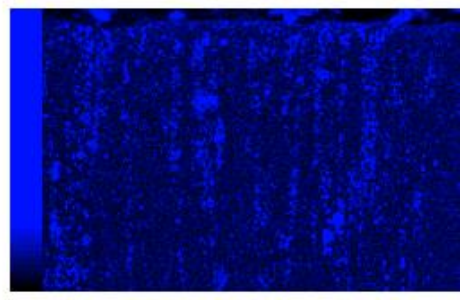

W M

Figura 76 - Mapeamento da distribuição de elementos químicos na seção transversal do punção 1

\subsection{Investigação de adesão}

A investigação da ocorrência de adesão na ferramenta mostrou-se desafiadora, pois os elementos químicos do material da peça (SAE 10B22) também estão presentes no material do punção (AISI M2), o que dificultou a determinação de partículas aderidas na superfície por meio de EDS. Dessa forma, a única maneira para determinar se a adesão estava presente foi procurar por saliências em toda extensão da superfície, com o auxílio de imagens em elétrons secundários obtidas em MEV e, em seguida, analisar se os elementos exclusivos do material da ferramenta ( $\mathrm{Cr}$, Mo, $\mathrm{V}$ e W) estavam ausentes de tal saliência. Por meio desse método, a partícula apontada na Figura 77 foi encontrada no raio do punção 2 . Observa-se que tal partícula não apresenta carbonetos, o que contrasta com o resto da superfície do punção. Além disso, os elementos químicos exclusivos do aço ferramenta M2 ( $\mathrm{Cr}$, Mo, V e W) aparentam estar ausentes da partícula, enquanto o $\mathrm{Fe}$, elemento o qual se concentra em áreas livres de carbonetos, preenche 
totalmente o contorno da partícula. Portanto, ainda que de forma não dominante, a adesão também é uma forma de desgaste presente no tribossistema analisado.
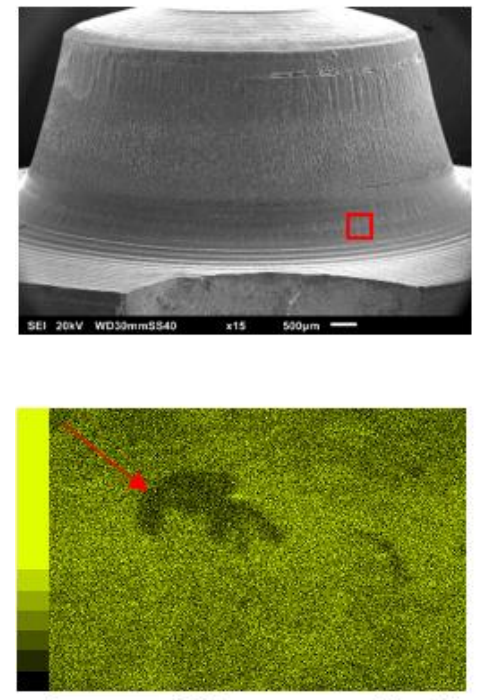

$30 \mu \mathrm{m}$

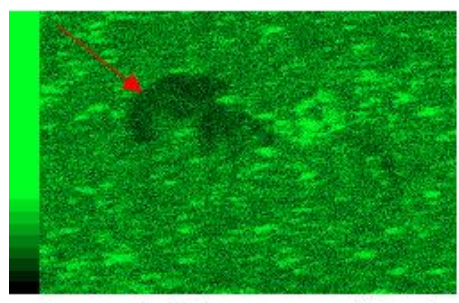

$30 \mu \mathrm{m} \quad$ Mo L

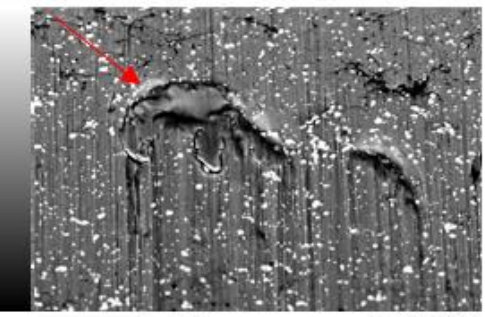

$30 \mu \mathrm{m}$
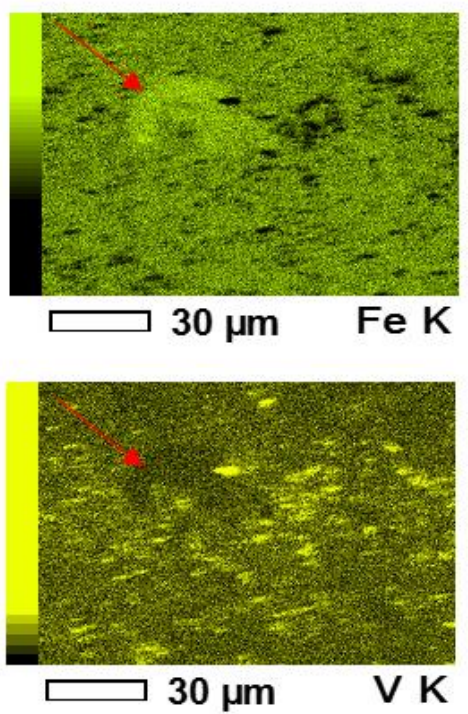

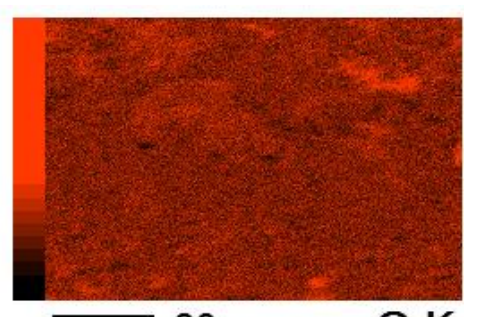

$30 \mu \mathrm{m}$

O K

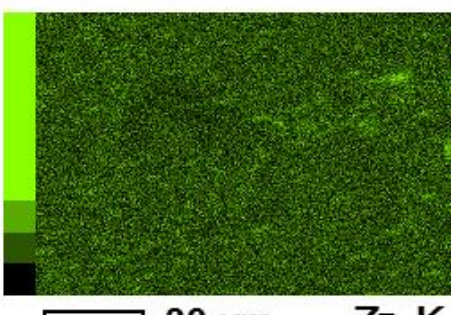

$30 \mu \mathrm{m} \quad$ Zn K

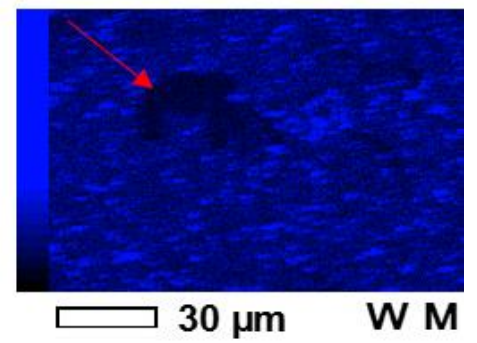

Figura 77 - Mapeamento da distribuição de elementos químicos no raio do punção 2

\subsection{Topografia da peça (contra-corpo)}

Apesar de a peça fabricada neste trabalho não exigir qualidade superficial alguma, analisou-se as regiões de interface com o objetivo de verificar se as superfícies apresentariam evidências sobre alterações no regime de lubrificação em função da rugosidade dos punções. Sabe-se que um sistema submetido ao regime de lubrificação limítrofe apresenta valores de coeficiente de atrito maiores do que o mesmo sistema submetido ao regime elasto-hidrodinâmico (DOWSON, 1979). Ou seja, verificou-se se a superfície das peças fabricadas com os punções "rugosos", os quais falharam prematuramente, diferiam significativamente das superfícies das peças fabricadas com os punções "intermediários" e "polidos".

A Figura 78 compara a topografia de três peças fabricadas com os três tipos de punção, sendo que a peça (a) foi fabricada com o punção 2 (rugoso), a peça (b) foi fabricada com o punção 7 (intermediário) e a peça (c) com o punção 12 (polido). 
Percebe-se que apenas a peça fabricada com o punção 2 (rugoso) apresenta marcas de usinagem provenientes do contato mecânico com a ferramenta. Isso sugere que para esse tribossistema o filme de óleo foi rompido, o que resultou em um regime de lubrificação limítrofe com contato mecânico entre as asperezas. Esse resultado corrobora com a explicação de que os punções "rugosos" falharam prematuramente devido à forças de atrito na interface de contato maiores do que as forças geradas com os punções "intermediários" e "polidos".

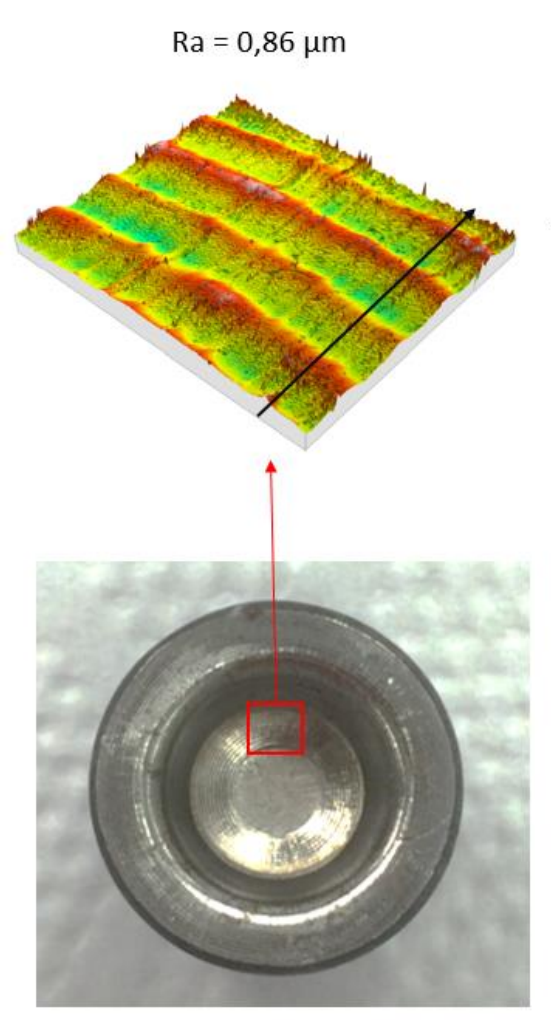

(a)

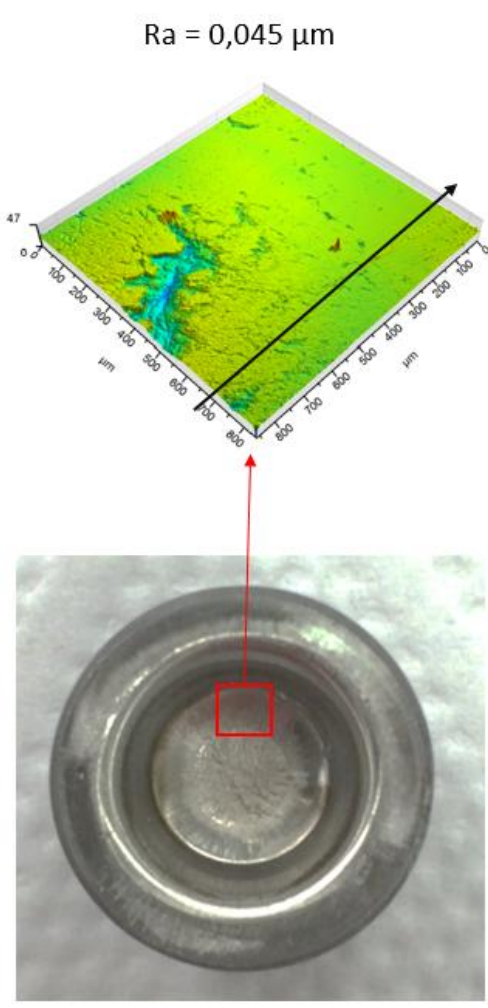

(b)

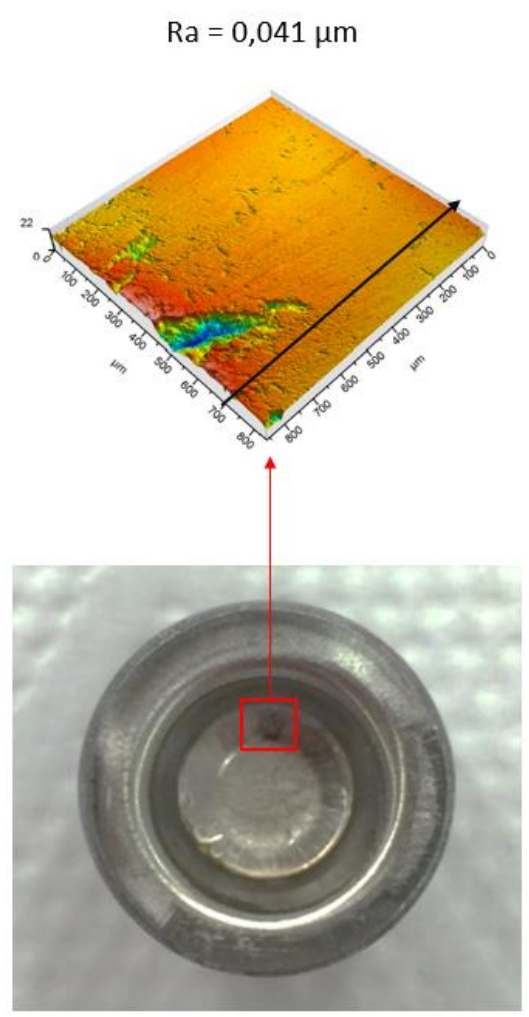

(c)

Figura 78 - Topografia de peças fabricadas com um punção rugoso (a), intermediário (b) e polido (c)

As peças (b) e (c), fabricadas respectivamente com os punções 7 (intermediário) e 12 (polido), não apresentaram nenhum tipo de impressão da ferramenta. Logo, nesses tribossistemas o filme de óleo entre a peça e a ferramenta foi preservado e, consequentemente, o nível de atrito para ambas as condições é equivalente. Além disso, não se observou diferença significativa, em termos de qualidade superficial, entre a peça fabricada com o punção "intermediário" e a peça fabricada com o punção "polido". 


\subsection{Análise do meio interfacial (óleo)}

A análise da membrana revelou que, de fato, existem partículas sólidas presentes no óleo refrigerante. A Figura 79 mostra algumas partículas sólidas, encontradas em regiões distintas da membrana, as quais estavam presentes no óleo refrigerante. A natureza de tais partículas pode ser originada de qualquer tribossistema da máquina utilizada. Além do contato entre a ferramenta e a peça produzida, componentes como engrenagens, eixos, rolamentos e buchas também sofrem desgaste e podem gerar partículas sólidas. Comparando o tamanho das partículas encontradas na membrana com as rugosidades dos punções apresentadas na seção 5.1.3, percebe-se que o tamanho das partículas é muito maior do que a distância entre os picos e vales dos punções. Ou seja, tais partículas presentes no meio interfacial entre peça e ferramenta, quando submetidas a altas cargas normais típicas do processo de conformação contribuem para o desgaste abrasivo dos corpos em contato. Portanto, desde que a rugosidade $R_{a}$ seja baixa suficiente para evitar o contato mecânico entre as asperezas e manter uma espessura mínima de filme de óleo, o processo de polimento dos punções torna-se dispensável para o tribossistema analisado, pois reduzir a rugosidade $R_{a}$ de $0,55 \pm 0,25 \mu \mathrm{m}$ para $0,15 \pm 0,05 \mu \mathrm{m}$ não evita os eventos abrasivos.

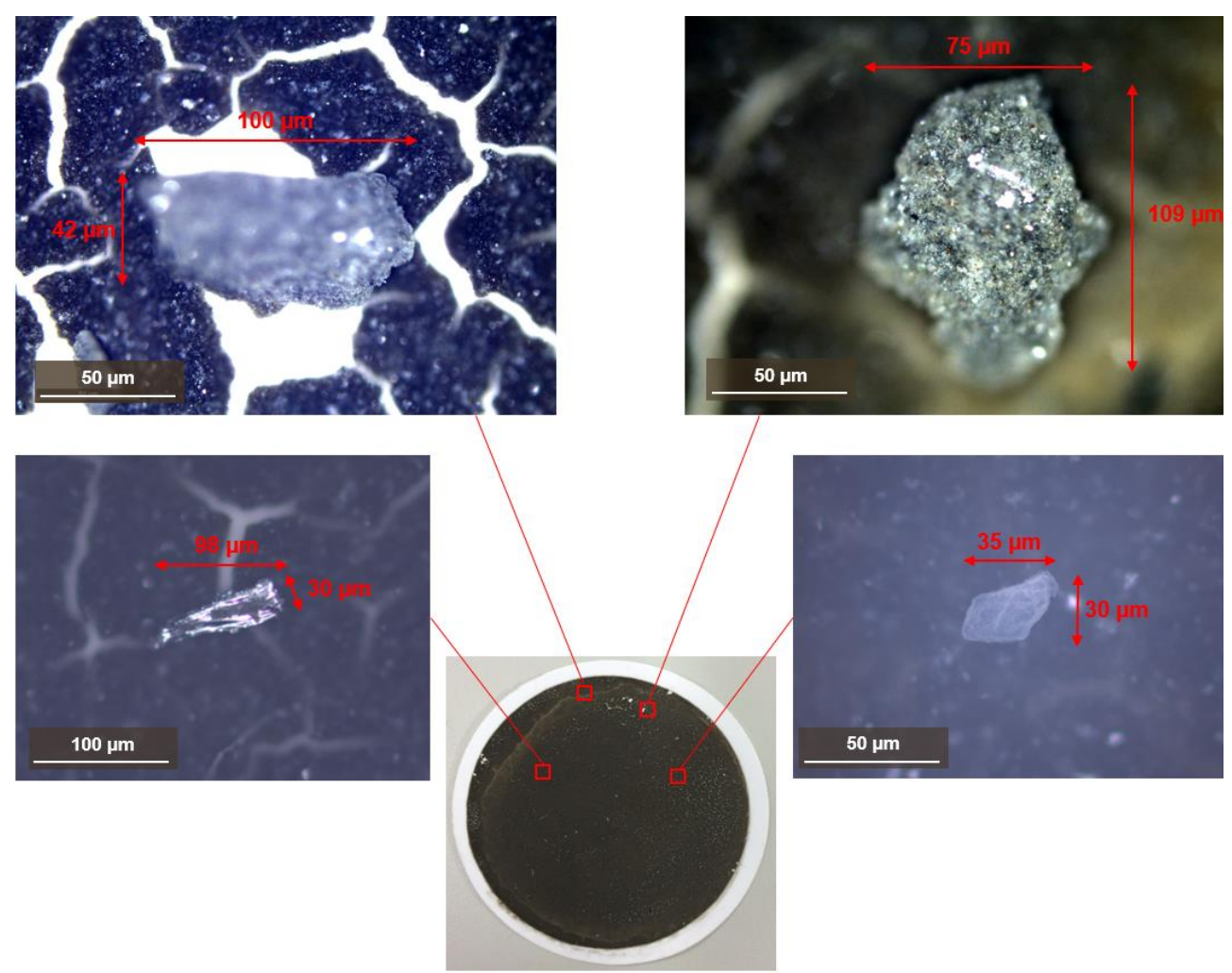

Figura 79 - Partículas sólidas encontradas no óleo refrigerante 


\section{CONCLUSÕES}

Os resultados experimentais apresentados ao decorrer deste trabalho permitem concluir que:

a) Regiões diferentes da ferramenta apresentam tipos de desgaste diferentes, sendo que o topo apresenta apenas desgaste abrasivo, enquanto a lateral além de abrasão também apresenta trincas nucleadas por atrito e propagadas possivelmente por fadiga e, ainda que de forma não dominante, a adesão também está presente.

b) Todos os punções rugosos com $R_{a}$ entre 1,5 e 2,5 $\mu \mathrm{m}$ quebraram prematuramente. Essa falha está relacionada com a topografia inicial dessas ferramentas, as quais oferecem maior resistência ao movimento e, consequentemente, maior tensão de cisalhamento causada por atrito na lateral da ferramenta.

c) Os punções intermediários com $R_{a}$ entre 0,3 e 0,8 $\mu \mathrm{m}$ e os punções polidos com $R_{a}$ entre 0,1 e $0,2 \mu \mathrm{m}$ apresentaram desgastes equivalentes, tanto no que tange perda de massa como perda dimensional.

d) Para o tribossistema analisado, é possível retirar o processo de polimento do fluxo de fabricação do punção, sem que haja redução na durabilidade da ferramenta. Considerando que o custo do polimento representa, em média, $20 \%$ do custo de fabricação de uma ferramenta de conformação a frio, espera-se que uma empresa que fabrica e consome ferramentas em larga escala obtenha grandes benefícios econômicos com o presente trabalho. 


\section{TRABALHO FUTUROS}

Ao longo deste trabalho, foram identificadas diversas oportunidades de pesquisas relacionadas ao tema abordado. Os potenciais trabalhos listados a seguir têm como objetivo aumentar a durabilidade das ferramentas de conformação e, consequentemente, reduzir os custos associados à fabricação das ferramentas, o que pode gerar uma grande vantagem econômica para uma forjaria.

a) Estender o resultado deste trabalho ao maior número possível de ferramentas similares utilizadas na Neumayer Tekfor Automotive Brasil Ltda.

b) Analisar qual é o melhor custo/benefício para ferramentas de conformação revestidas com diversos tipos de filmes finos (TiN, TiAICN, AICrN e DLC).

c) Elaborar uma especificação de engenharia para assegurar a qualidade do filme fino depositado sobre a superfície das ferramentas.

d) Estudar se ferramentas fabricadas com outro tipo de matéria-prima geram um custo/benefício melhor do que as utilizadas atualmente.

e) Otimizar o ciclo de tratamento térmico utilizado na fabricação das ferramentas.

f) Estudar o efeito do refinamento da microestrutura do aço ferramenta para verificar se carbonetos maiores podem atuar como barreiras para os eventos abrasivos, sem que haja perda significativa na tenacidade da ferramenta.

g) Estudar se aumentar a frequência da troca de óleo e do filtro da máquina apresenta um custo/benefício melhor do que atual. 


\section{REFERÊNCIAS}

ASSOCIAÇÃO BRASILEIRA DE NORMAS TÉCNICAS. NBR 14677. Aço Determinação do grau de esferoidização de carbonetos - Método de ensaio. Rio de Janeiro, 2001. $21 \mathrm{p}$.

NBR NM ISO 6507-1. Materiais metálicos - Ensaio de dureza Vickers. Parte 1: Método de ensaio. Rio de Janeiro, 2008. 22 p.

ACERO, J. S. R. Influência do acabamento superficial no desempenho de lubrificantes de motor novos e usados em automóveis abastecidos com E22 e E100. 2015. 103 f. Dissertação de Mestrado em Engenharia Mecânica Universidade de São Paulo, São Paulo, 2015.

AMERICAN SOCIETY FOR METALS. Friction, lubrication and wear technology. United States of America: ASM HANDBOOK, v. 18, 1992.

American Society for Testing and Materials. E 112 - 96. Standard Test Methods for Determining Average Grain Size. Pennsylvania, 2004. 26 p.

BLAU, P. J. Friction Science and Technology: from concepts to applications. 2nd ed. Boca Raton: CRC Press - Taylor \& Francis Group, 2009.

DIN 8580, Manufacturing processes - Terms and definitions, division. Deutsches Institut Fur Normung, 2003.

DELEANU, L.; GEORGESCU, C.; SUCIU, C. A Comparison between 2D and 3D surface parameters for evaluating the quality of surfaces. The Annals of Dunârea de Jos. University of Galati, fascicle V. Technologies in machining building, ISSN 1221-4566, 2012.

DIETER, G. E. Mechanical Metallurgy. SI metric ed. Singapore: MecGraw-Hill Book Company, 1988.

DOWSON, D. History of tribology. $2^{\text {nd }}$ ed. United Kingdom: John Wiley and Sons Ltd., 1999. 
ENGEL, U. et al. Tooling solutions for challenges in cold forging. Disponível em <http://www.umformtechnik.net/whitepaper/tooling-solutions-of-challenges-in-coldforging_17041/>. Acesso em: 27 jun. 2016.

EUROFORGE. Global Trends. Disponível em <www.euroforge.org>. Acesso em: 10 jul. 2015.

FALCONNET, E.; CHAMBERT, J.; MAKICH, H.; MONTEIL, G. Prediction of abrasive punch wear in copper alloy thin sheet blanking. Wear, n. 338-339, p. 144-154, 2015.

GATES, J. D. Two-body and three-body abrasion: A critical discussion. Wear, n. 214, p. 139-146, 1998.

GROENBAEK, J. RAP - Robot Assisted Polishing - Roboterunterstütztes Polieren von Umformwerkzeugen, 23. Jahresteffen der Kaltmassivumformer, VDI, Düsseldorf, Jan 2008. English version: Workshop "Steel polishing Fraunhofer Institute for Production Technology, Aachen, Oct 2008.

HIOKI, D. Influência dos parâmetros de corte do fresamento HSM sobre o desempenho tribológico do aço AISI H13 endurecido. 2006. 233 f. Tese de Doutorado em Engenharia Mecânica - Universidade de São Paulo, São Paulo, 2006.

HIRSCHVOGEL, M.; DOMMELEM, H.V. Some applications of cold and warm forging. Journal of Materials Processing Technology, v.35, p. 343-356, 1992.

HUTCHINGS, I. M. Tribology: Friction and Wear of Engineering Materials. 1st ed. London: Edward Arnold, 1992.

. Leonardo da Vinci's studies of friction. Wear, v. 360-361, p. 51-66, 2016.

JOST, H. P. Tribology - Origin and future. Wear, v. 136, p. 1-17, 1990.

KOMVOPOULOS, K.; SAKA, N.; Suh, N. P. The Mechanisms of friction in Boundary Lubrication, Transactions ASME. Journal of Tribology, v. 107, p. 452-463, 1985.

MAGRI, M. L. Influência da topografia superficial na vida da matriz de forjamento a quente. 2011. 160 f. Dissertação de Mestrado em Engenharia Mecânica - Universidade Estadual de Campinas, Campinas, 2011. 
MENDES, M. A. Estudo do desgaste de ferramentas com e sem revestimentos de filmes finos utilizadas em operações de conformação a frio. 2009. $73 \mathrm{f}$. Dissertação de Mestrado em Engenharia Mecânica - Universidade de São Paulo, São Paulo, 2009.

NEUMAYER TEKFOR AUTOMOTIVE BRASIL LTDA. Relatório interno, 2015.

OLYMPUS CORPORATION. Disponível em: <http://www.olympusims.com/pt/knowledge/metrology/roughness/3d_parameter/>. Acesso em: 20 jun. 2016.

PHYS.ORG, News and Articles on Science and Technology. Disponível em: <http://phys.org/news/2014-04-ancient-egyptians-pyramid-stones-sand.html>. Acesso em: 11 jun. 2016.

PODGORNIK, B.; HOGMARK, S.; SANDERBERG, O. Influence of surface roughness and coating type on the galling properties of coated forming tool steel. Surface and Coatings Technology, v. 184, p. 338-348, 2004.

; JERINA, J. Surface topography effect on galling resistance of coated and uncoated tool steel. Surface and Coatings Technology, v. 206, p. 27922800, 2012.

; LESKOVSEK, V. Wear mechanisms and surface engineering of forming tools. Materials and Technology, v. 49, p. $313-324,2015$.

POLOK-RUBINIEC, M. et al. Comparison of the structure, properties and wear resistance of the TiN PVD coatings. Journal of Achievements in Materials and Manufacturing Engineering, v. 27, p. 87-90, 2008.

RABINOWICZ, E. Friction and wear of materials. 2nd ed. New Jersey: John Whiley and Sons, 1995. 
SACMA GROUP. Disponível em: <http://www.sacmagroup.com/pt/winningtechnologies/projeto-de-ferramental.ow?pageld=12949>. Acesso em: 6 mai. 2016.

SCHEY, J. A. Tribology in metalworking: friction, lubrication and wear. American Society for Metals, 2 ed., 1984.

SCHMOLZ BICKENBACH GROUP. Disponível em: <https://www.dewstahl.com/fileadmin/files/dew-stahl.com/documents/Publikationen/Broschueren/072_ DEW_Werkstoffauswahl_Kaltarbeit_GB.pdf>. Acesso em: 10 jan. 2016.

SEDLACEK, M.; PODGORNIK, B.; VIZINTIN, J. Influence of surface preparation on roughness parameters, friction and wear. Wear, n. 266, p. 482-487, 2009.

SEIREG, A. A. Friction and Lubrication in Mechanical Design. 1st ed. New York: Marcel Dekker Inc., 1998.

SHEU, S.; HECTOR, L.; RICHMOND, O. Tool surface topographies for controlling friction and wear in metal-forming processes. Journal of Tribology, v. 120, p. 517$527,1998$.

SOUZA, M. M.; PEREIRA, M. H.; SOUZA, T.S.G. Fabricação e caracterização de componentes forjados para transmissões. In: 12ำ Simpósio SAE Brasil de Powertrain, Sorocaba, 2014.

STACHOWIAK, G. W.; BATCHELOR, A. W. Engineering Tribology. 4th ed. Elsevier, 2013.

TILLMANN, W.; VOGLI, E.; MOMENI, S. Improvement of press dies used for the production of diamond composites by means of DUPLEX-PVD-coatings. Surface and Coatings Technology, v. 205, p. 1571-1577, 2010.

TREZONA, R.; ALLSOPP, D.; HUTCHINGS, I. Transitions between two-body and three-body abrasive wear: Incluence of test conditions in the microscale abrasive wear test. Wear, n. 225, p. 205-214, 1999.

UEHARA, S. Influência do acabamento superficial no desempenho de bronzinas, 2005. 143 f. Dissertação de Mestrado em Engenharia Mecânica Universidade de São Paulo, São Paulo, 2005. 
WHITEHOUSE, D. J. Handbook of surface metrology. Philadelphia Institute of Physics Publishing, 1994.

WILSON, W. R. D. Tribology in cold metal forming. Journal of Manufacturing Science and Engineering, v. 119, p. 695-698, 1997.

WRENTHAM TOOL GROUP. Disponível em: <www.wrenthamtool.com>. Acesso em: 10 fev. 2016.

ZUM GAHR, K. H. Microstructure and wear of materials. New York: Elsevier, 1987. 